Florida International University FIU Digital Commons

3-20-2018

\title{
Financial Sector Development, Economic Growth and Stability
}

Wenjun Xue

Florida International University,wxue005@fiu.edu

DOI: 10.25148 /etd.FIDC004085

Follow this and additional works at: https://digitalcommons.fiu.edu/etd

Part of the Econometrics Commons, and the Finance Commons

\section{Recommended Citation}

Xue, Wenjun, "Financial Sector Development, Economic Growth and Stability" (2018). FIU Electronic Theses and Dissertations. 3715. https://digitalcommons.fiu.edu/etd/3715

This work is brought to you for free and open access by the University Graduate School at FIU Digital Commons. It has been accepted for inclusion in FIU Electronic Theses and Dissertations by an authorized administrator of FIU Digital Commons. For more information, please contact dcc@fiu.edu. 


\title{
FLORIDA INTERNATIONAL UNIVERSITY
}

Miami, Florida

FINANCIAL SECTOR DEVELOPMENT, ECONOMIC GROWTH AND STABILITY

\author{
A dissertation submitted in partial fulfillment of \\ the requirements for the degree of \\ DOCTOR OF PHILOSOPHY
}

in

ECONOMICS

by

Wenjun Xue

2018 
To: Dean John F. Stack, Jr.

Green School of International and Public Affairs

This dissertation, written by Wenjun Xue, and entitled Financial Sector Development, Economic Growth and Stability, having been approved in respect to style and intellectual content, is referred to you for judgment.

We have read this dissertation and recommend that it be approved.

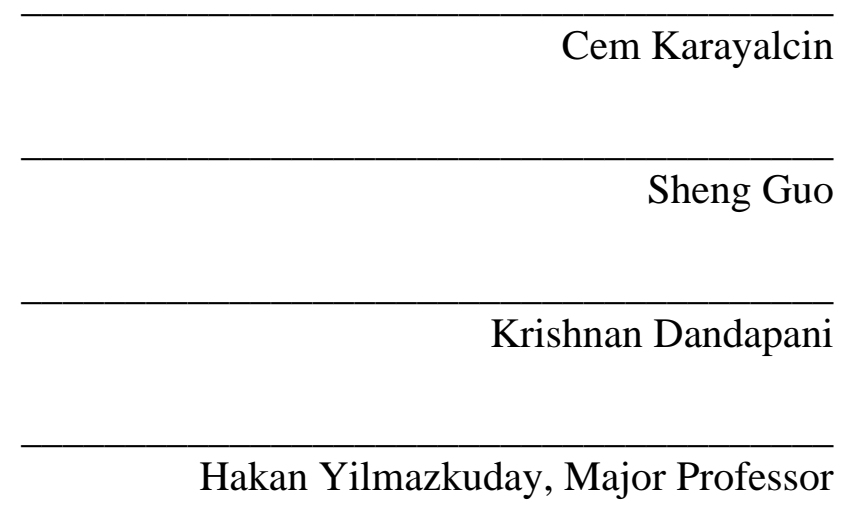

Date of Defense: March 20, 2018

The dissertation of Wenjun Xue is approved.

Dean John F. Stack, Jr. Green School of International and Public Affairs

Andrés G. Gil

Vice President for Research and Economic Development and Dean of the University Graduate School

Florida International University, 2018 
(C) Copyright 2018 by Wenjun Xue

All rights reserved. 
DEDICATION

For my family 


\section{ACKNOWLEDGMENTS}

I would like to express my sincere gratitude to my advisor Dr. Hakan Yilmazkuday for his guide. I want to thank the other committee members (Dr. Cem Karayalcin, Dr. Sheng Guo and Dr. Krishnan Dandapani) for their suggestions. I also wish to acknowledge Dr. Mihaela Pintea and Mrs. Mayte Rodriguez for their administrative support. Finally, I am indebted to my family and friends. 
ABSTRACT OF THE DISSERTATION

FINANCIAL SECTOR DEVELOPMENT, ECONOMIC GROWTH AND STABILITY

by

Wenjun Xue

Florida International University, 2018

Miami, Florida

Professor Hakan Yilmazkuday, Major Professor

My dissertation investigates financial sector development, economic growth and stability through the analysis of Chinese and international evidence. My first chapter is the introduction. The second chapter investigates the effects of Chinese financial and fiscal policies on the Chinese economic recovery in the 2008 economic stimulus Plan, covering the period from the Great Recession to 2014. This chapter explores the effects of the increase in bank credit growth with significant strain of banking health on firm-level output, employment and investment. The results demonstrate that the increase in government expenditure due to the fiscal policies has the significant effects on the very same firm-level indicators. The effects of such policies are shown to depend on firm characteristics such as size, liability ratio, profitability, ownership and industry. Regarding the dynamic effects of the policies, it is documented that the roles of Chinese financial and fiscal policies are effective but temporary on the Chinese economic recovery within about 2 years. 
In the third chapter, I investigate the effects of financial sector development on the growth volatility by using the data of 50 countries. The empirical results show that the aggregate growth volatility declines from 1997 to 2014 in the global perspective while the advanced countries have much smaller growth volatility than the developing countries. Using the dynamic panel threshold model, I find that financial sector development significantly reduces growth volatility, especially in its lower regime. Financial sector development magnifies the shock of inflation volatility towards growth volatility in its higher regime. My results reveal the importance of keeping financial sector development at an optimal level, which is beneficial to reduce aggregate fluctuations and dampen the inflation shocks.

The fourth chapter examines the asymmetric roles of bank credit on the business cycle by using international evidence. The empirical results present that bank credit is pro-cyclical and amplifies the business cycle. This effect is larger in the economic peak and trough, which forms a U-shaped curve. The U-shaped influences are robust for alternative financial factors, including M2 supply and stock price. This paper contributes to explore the distinct roles of bank credit on the economy in different business cycle phases. 
2. THE ROLES OF THE CHINESE BANKING SYSTEM AND 2008 ECONOMIC STIMULUS PLAN IN THE CHINESE ECONOMIC RECOVERY ………….............. 6

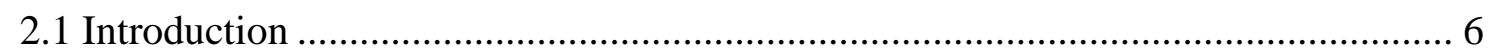

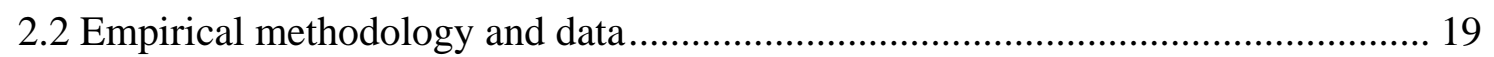

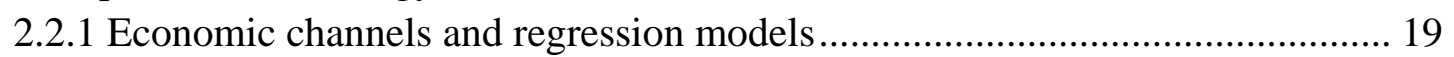

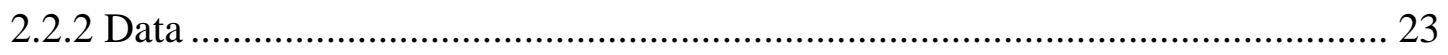

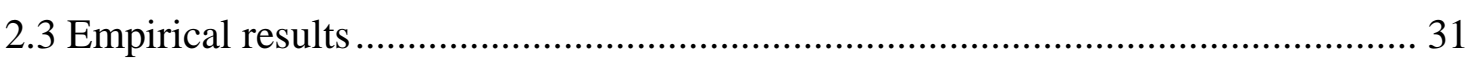

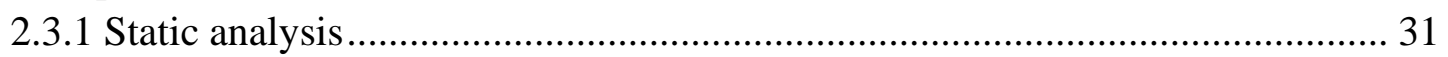

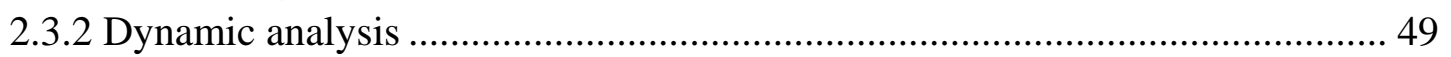

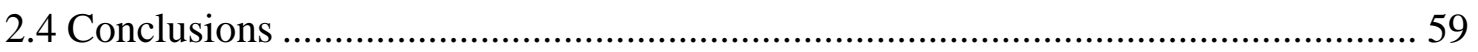

3. FINANCIAL SECTOR DEVELOPMENT AND GROWH VOLATILITY .................. 61

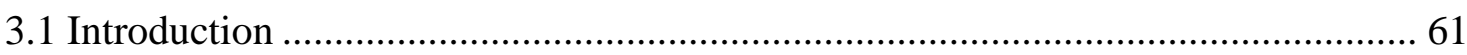

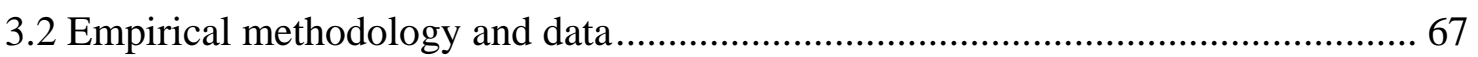

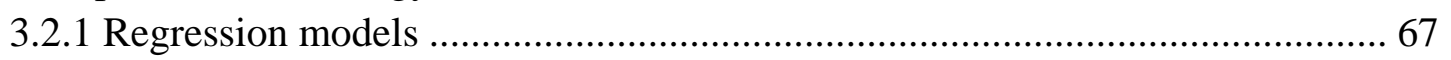

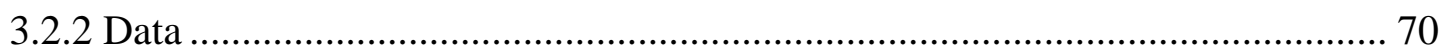

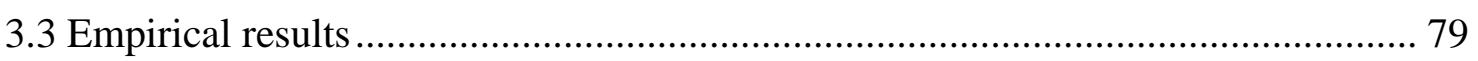

3.3.1 The roles of financial sector development on the growth volatility.................. 79

3.3.2 The roles of financial sector development with the inflation volatility shock.. 83

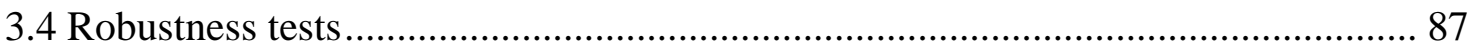

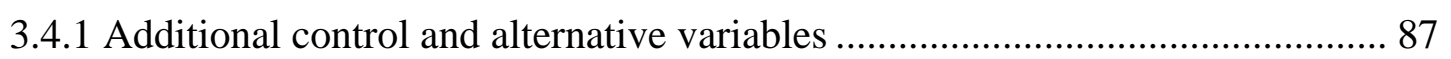

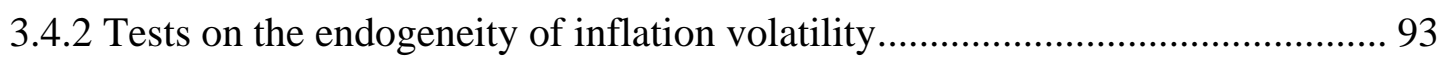

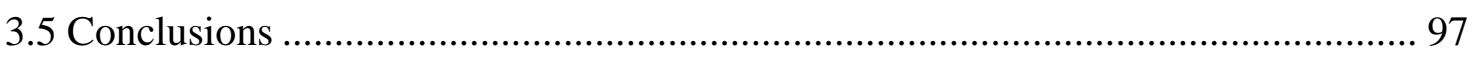

4. REVISTING BANK CREDIT AND THE BUSINESS CYCLE …………….......... 99

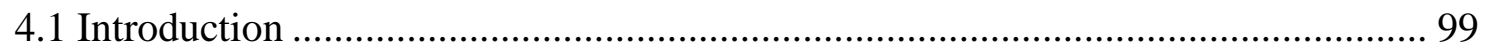

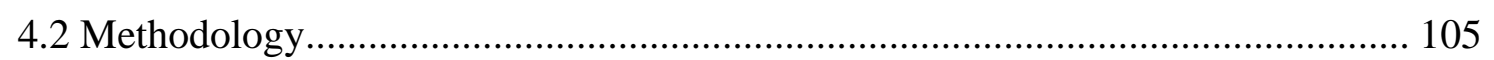

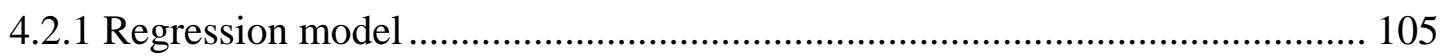

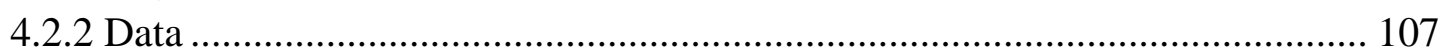

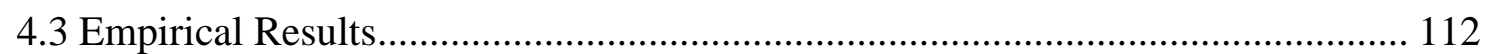

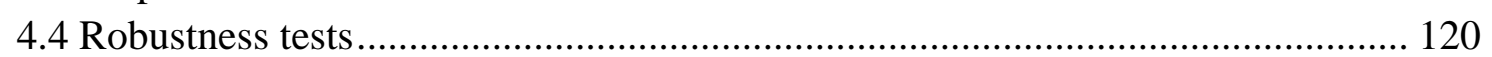

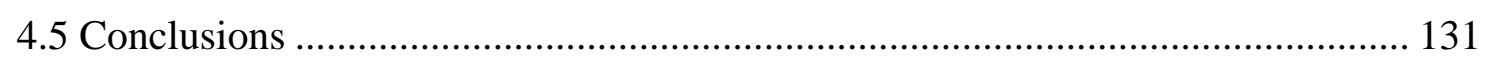




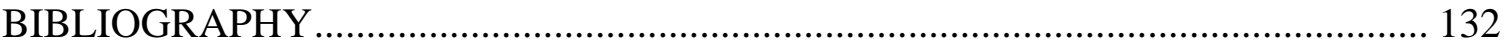

VITA 


\section{LIST OF TABLES}

TABLE

PAGE

Table 2.1 Variables and their meanings............................................................... 23

Table 2.2 Descriptive statistics of firms' characteristics .......................................... 27

Table 2.3 Correlation coefficients of credit and banking health indicators ..................... 30

Table 2.4 Results on firm-level variables: Linear model............................................ 33

Table 2.5 Results on firm-level variables: Size ........................................................... 39

Table 2.6 Results on firm-level variables: Liability .............................................. 40

Table 2.7 Results on firm-level variables: Profitability ........................................... 41

Table 2.8 Results on firm-level variables: Ownership............................................. 44

Table 2.9 Results on the regression models with interaction effects ............................ 50

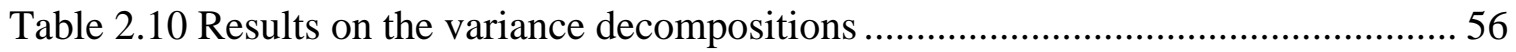

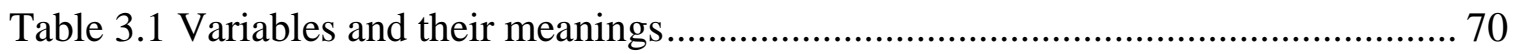

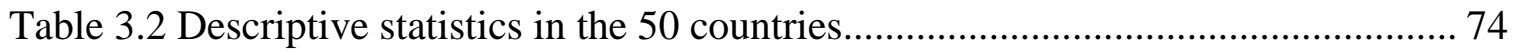

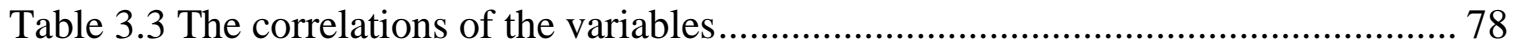

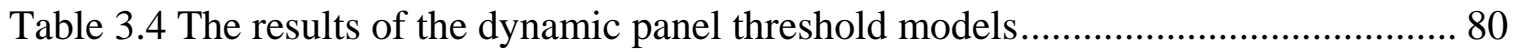

Table 3.5 The results of the dynamic panel threshold models in the advanced and

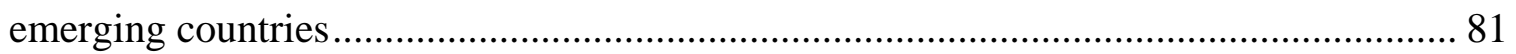

Table 3.6 The results of the dynamic panel threshold models with interaction effects.... 85 
Table 3.7 The results of the dynamic panel threshold models with interaction effects in the advanced and emerging countries

Table 3.8 The results of the dynamic panel threshold models with additional control variables

Table 3.9 The results of the dynamic panel threshold models with interaction effects of PPI volatility 92

Table 3.10 The results of the dynamic panel threshold models using more instrument variables

Table 3.11 The results of the dynamic panel threshold models with interaction effects using more instrument variables

Table 4.1 Variables and meanings 109

Table 4.2 The basic features of the business cycle 110

Table 4.3 The correlations of the variables.

Table 4.4 The results of the quantile regression for each sample country..... 115

Table 4.5 The results of the panel quantile regression

Table 4.6 The results of the panel quantile regression in the advanced and emerging countries

Table 4.7 The results of the panel quantile regression with additional control variables 122

Table 4.8 The results of the panel quantile regression in the advanced and emerging countries with additional control variables

Table 4.9 The results of the dynamic panel quantile regression

Table 4.10 The results of the dynamic panel quantile regression in the advanced and emerging countries. 126 
Table 4.11 The results of the panel quantile regression in the different horizons

Table 4.12 The results of the panel quantile regression with M2 supply 129

Table 4.13 The results of the panel quantile regression with stock price 130 


\section{LIST OF FIGURES}

FIGURE

PAGE

Figure 2.1 Transmission channels of money, credit and banking system in the economy 20

Figure 2.2 The trend of the macroeconomic variables from 2008 to $2014 \ldots \ldots \ldots \ldots \ldots \ldots \ldots \ldots . . .29$

Figure 2.3 Results of the impulse response functions................................................... 52

Figure 3.1 The trend of aggregate growth volatility from 1997 to $2014 \ldots \ldots \ldots \ldots \ldots \ldots \ldots \ldots \ldots \ldots . . .73$

Figure 3.2 The country-level growth volatility of the 50 countries.................................. 76 


\section{CHAPTER 1}

\section{INTRODUCTION}

The relationships among financial sector development, economic growth and stability are widely investigated. There are three main strands of these papers to explore this field. Regarding financial sector development and economic growth, it is thought that a healthy financial sector can help allocate capital to the highest valued investments without substantial risk of loss and large transaction costs. It can also reduce the cost of external finance and overcome informational asymmetries, allowing firms to partake in worthwhile investment opportunities and more easily reduce investment in liquid but unproductive assets (Schumpeter, 1912; Greenwood and Jovanovic, 1990; Levine, 1997; Rajan and Zingales, 1998).

In the case of financial sector development and economic stability, some papers investigate the roles of financial sector development on the growth volatility and document how financial sector development can smoothen investment, consumption, diversify portfolios, manage production risks, generate information about the risks and returns of investments and then decrease growth volatility (Greenwood and Jovanovic, 1990; King and Levine, 1993, Obstfeld, 1994; Acemoglu and Ziliboti, 1997; Levine, 1997). Aghion et al. (1999), Caballero and Krishnamurty (2001) and Denizer et al. (2002) argue that financial sector development can absorb economic shocks. Bernanke 
and Gertler (1989, 1990) and Kiyotaki and Moore (1997) document that market imperfections and restrictions can amplify macroeconomic shocks. Meanwhile, Schumpeter (1934) and Gurley and Shaw (1955) emphasize the close relationship between the financial cycle and the business cycle. Bernanke et al. (1996) and Kiyotaki and Moore (1997) find that financial factors can amplify business cycle fluctuations and the roles played by movements in credit and asset price in shaping macroeconomic aggregate changes over the business cycle.

Inspired from these classical papers, I investigate a number of topics. The first is to explore the roles of the Chinese banking system and the 2008 economic stimulus plan in the Chinese economic recovery. It is known that the Great Recession significantly harms the Chinese economy that depends on its exports. In order to prevent the Chinese economy from slowing down further, with the goal of a growth rate above $8 \%$, the Chinese government launches the "RMB 4-trillion stimulus plan" in November 2008. It is estimated that the new growth of the bank credit in China reaches about RMB 14.6 trillion. The effects of such policies, however, depend on how the Chinese banking system utilizes this additional liquidity. Within this picture, in order to identify these real effects of Chinese banking system and "RMB 4-trillion stimulus plan", using firm-level data from China, I search for the main determinants of firm-level output, employment and investment. The results show that firm output, employment and investment have a significant interaction. I find that banking health ratios and credit supply, together with 
the increase in government expenditure, are the main determinants of these three main firm activities, especially for firm investment.

Second, I investigate which firms have benefited more from these financial and fiscal policies, after controlling for some external economic factors. The results show that a healthy banking system and credit supply are more effective on the investment of larger firms and state-owned firms but their roles on output are less on the smaller firms and private firms. A healthy banking system and credit supply are shown to be more effective on the high- and medium-liability firms in regards to output and investment. Besides, higher profitable firms receive more credit support compared to medium and low profitable firms. In the end, by taking advantage of the impulse reaction functions, I explore the dynamic interaction of firm-level output, employment and investment and dynamic effects from financial, fiscal policies and external economic factors. The results also show that three firm-level indicators have the dynamic significant interaction. Furthermore, firm-level output, employment and investment positively respond to the shocks of financial and fiscal policies but the positive shocks converge very quickly in around 2 years. It shows that Chinese financial and fiscal policies work temporarily during the Great Recession (2008-2009).

The second chapter investigates the important effects of financial sector development on the growth volatility and explores whether financial sector development magnifies or dampens the economic shocks. By investigating the growth volatility in the 50 countries 
from 1997 to 2014, I find that growth volatility in the world exhibits a declining trend but increases during the South American Economic Crisis (2002-2003), the Global Financial Crisis (2008-2009) and the European Debt Crisis (2010-2012). The advanced countries have smaller growth volatility than emerging countries. By applying the dynamic panel threshold model, it is evident that growth volatility has a significant positive first lagged autocorrelation pattern. Financial sector development could reduce growth volatility in the lower regime by using the proxies of banking credit and health indicators. Regarding the shock of inflation volatility, I confirm that financial sector development can magnify its effect to the growth volatility in the higher regime, especially in the advanced countries. Furthermore, it is documented that economy size and trade openness have significant positive influences on the growth volatility.

In the robustness tests, it is evident that financial openness, human capital investment, law and institution quality significantly reduce growth volatility. To handle the endogeneity in the models, I apply the first lagged inflation volatility and the central bank assets to GDP as the instrument variables to replace inflation volatility, respectively. The results acknowledge that my results are very robust, that is, inflation volatility positively affects the growth volatility and excessive financial sector development magnifies the shock of inflation volatility on the growth volatility. Overall, my paper contributes to reveal the importance of financial sector development on the aggregate fluctuations in the global perspective. 
Considering the co-movement between financial factors and the business cycle, I examine the asymmetric roles of bank credit on the business cycle by using international evidence. The results show that bank credit is pre-cyclical and greatly amplifies the business cycle in this peak and trough, which forms a U-shaped curve. Compared with the advanced and emerging counties, it is evident that the effects of bank credit are larger in the emerging countries than advanced countries. The business cycle after the financial crisis is less fluctuated because of the higher capital requirement and the more risk-sensitiveness standard.

In the robustness tests, the U-shaped effects of bank credit on the business cycle are also significant after using additional control variables and regarding the dynamics of the business cycle. Besides, I find that the effects of bank credit on the business cycle gradually diminish as time goes by. After using other alternative financial factors, including M2 supply and stock price, this paper suggests that the effects of M2 supply and stock price also shows a U-shaped curve, which shows that financial factors play a larger effect in the economic recessions and booms. Overall, this paper contributes to exploring the distinct roles of financial factors on the economy in the different business cycle phases in the global perspective. 


\section{CHAPTER 2}

\section{THE ROLES OF THE CHINESE BANKING SYSTEM AND 2008 ECONOMIC STIMULUS PLAN IN THE CHINESE ECONOMIC RECOVERY}

\subsection{Introduction}

The Great Recession has significantly harmed the Chinese economy, which depends on the country's exports. In the first three quarters of 2008, Chinese GDP growth rate dropped to about $9 \%$ (from the peak levels of about $15.4 \%$ ) and is predicted to decline further. In order to prevent the Chinese economy from further slowing down, with the goal of a growth rate above $8 \%$, the Chinese government has launched the "RMB 4-trillion stimulus plan" in November 2008. In addition, the Chinese central bank has cut the benchmark interest rate, the deposit reserve ratio and has abolished the credit constraints of the commercial banks to achieve steady growth of credit and increase the liquidity in financial institutions; it has been estimated that the new growth of the bank credit in China has reached about RMB 14.6 trillion (RMB 4.7 trillion in 2008 and RMB 9.6 trillion in 2009). The effects of such policies, however, depend on how the Chinese banking system has utilized this additional liquidity.

In this context, I investigate the roles of the Chinese banking system and Chinese 2008 economic stimulus plan on the Chinese economic recovery from the Great Recession to 
$2014^{1}$. My motivation is based on two strands of literature. The first strand is earlier studies focusing on the positive effects of a healthy banking system on increasing the allocation efficiency to the highest valued investments, reducing the cost of external finance and transaction costs, and promoting economic growth (Schumpeter, 1912; Levine, 1997; Rajan and Zingales, 1998); such positive effects are also reflected in credit quality and quantity (Bernanke, 1983; Hasan et al., 2009; Koetter and Wedow, 2010). The second strand refers that the Chinese banking system is influenced by the government to serve both political and economic goals and sometimes have to finance state-owned enterprises in loss (Cull and Xu, 2003; Allen et al., 2005; Firth et al., 2009; Chen et al., 2013). In addition, the Chinese banking system is also regarded to play a essential role on funding government expenditure in "RMB 4-trillion stimulus plan" and following the loosened monetary policy and signals from the central government to increase bank credit supply to promote economic recovery (Wen and Wu, 2014; Liu et al., 2018).

In order to identify these real effects of the Chinese banking system and "RMB 4-trillion stimulus plan", using firm-level data from China, I search for the main determinants of firm-level output, employment and investment. The results show that firm output, employment and investment have significant interaction. The increase in firm employment and investment positively affects output but the positive role of investment on output is weak. The increased firm output reversely promotes the growth of employment

${ }^{1}$ The 2008 Chinese economic stimulus plan is a RMB 4 trillion (US\$586 billion) stimulus package announced by the State Council of the People's Republic of China on 9 November 2008 as an attempt to minimize the impact of the global financial crisis on China. 
and investment. Furthermore, I find that banking health ratios (i.e., asset liquidity, capital adequacy ratio, profitability, and bad loan ratio) and credit supply, together with the increase in government expenditure, are the main determinants of these three main firm activities, especially for firm investment. It is implied that the Chinese banking system and the economic stimulus plan have played essential roles to stimulate investment and helps for the Chinese economic recovery from the Great Recession to 2014.

Second, I investigate which firms have benefited more from these financial and fiscal policies, after controlling for some external economic factors. My motivation is based on studies focusing on the role of firm characteristics (such as size or ownership) on credit constraints in the case of different countries (Berger and Udell, 1998; Galindo and Schiantarelli, 2003; Huang, 2008; Chan et al., 2012; Poncet et al., 2010; Liu et al., 2018). I base my investigation on firm-specific characteristics such as size, liability ratio, profitability, ownership and industry. The results show that a healthy banking system and credit supply are more effective on the investment of larger firms and state-owned firms but their roles on output are smaller than smaller firms and private firms, which reflect the low financial constraints and investment efficiency for larger firms and state-owned firms. Regarding the liability ratio of firms, a healthy banking system and credit supply are shown to be more effective on the high- and medium-liability firms on output and investment. Besides, higher profitable firms receive more credit support compared to medium and low profitable firms. 
Regarding the industry of firms, consistent with the "top ten industry revitalization plan" promulgated by the Chinese government in early 2009, certain industries have benefited more from financial and fiscal policies. ${ }^{2}$ Fiscal policy through the increase in government expenditure is shown to be effective on firm-level output, employment and investment, regardless of the size, liability ratio, profitability, ownership and industry of firms, although the magnitude of such effects are shown to depend on these firm characteristics. Net export and US financial market performance also affect the various types of Chinese firms. I also compare the roles of financial and fiscal policies in the Great Recession (2008-2009) and recovery period (2010-2014) and observe that the positive roles of financial and fiscal policies are much larger in the Great Recession than recovery period. It supports the success of "RMB 4-trillion stimulus plan" in the Great Recession but the effect of these polices diminishes very quickly.

In the end, by taking advantage of the impulse reaction functions, I explore the dynamic interaction of firm-level output, employment and investment and dynamic effects from financial, fiscal policies and external economic factors. The result also present that three firm-level indicators have dynamic significant interaction. Furthermore, firm-level output, employment and investment positively respond to the shocks of financial and fiscal

2 The existing literature has also focused on the roles of financial development on certain industries (Kletzer and Bardhan, 1987; Rajan and Zingales, 1998; Wurgler, 2000). This paper is connected to such studies as well by showing that industries such as agriculture, utility, manufacturing and transportation and warehousing industries are heavily supported by banking credit in China, in line with the government policies. Within this picture, it is also shown that a large amount of credit is provided for real estate and construction industries due to vast investment profits, feeding the overheating in the Chinese housing market. 
policies but the positive shocks converge very quickly in around 2 years. The explanation capacities of financial and fiscal policies are very large for firm investment but are not large for output in line with the results of the variance decomposition. Both results mean that the effects of Chinese financial and fiscal policies might be led by Chinese government so that these effects are temporary and are not very effective on output.

Starting from 1980, the Chinese government carried on a series of bank reforms to promote financial development, including establishing four state-owned specialized banks to implement the government plan and control credit size (1980-1993), promoting the transition of the state-owned banks to the commercial banks and setting up some joint-stock commercial banks (1993-1997), helping strip the non-performing assets to further improve performance (1997-2003) and injecting the fund to solve bad loan problems in 2003. After the reforms mentioned so far, Chinese commercial banks achieved large improvements. By the end of 2007, nonperforming loan ratio of the state-owned commercial banks was $3 \%$, which was far below the level before the reform. Capital adequacy ratio was higher than the requirements of the Basel capital adequacy. Besides, by the initial public offering, four state-owned banks built a market-oriented mechanism to standardize the information disclosure and strengthen the duties regulation on the senior management. These were important policies to achieve a well-organized banking system. However, it is documented that the Chinese banking system is influenced by the government, especially with some objectives set by politicians and bureaucrats, to serve 
both political and economic goals (Cull and $\mathrm{Xu}, 2003$ ). Meanwhile, the Chinese banking system is dominated by the government through direct and indirect state ownership, while these banks' lending decisions often reflect government-dictated policies and have to finance state-owned enterprises, which sometimes are in loss (Allen et al., 2005; Firth et al., 2009; Chen et al., 2013).

Facing the 2008 global financial crisis, the Chinese government announced the "RMB 4-trillion stimulus plan". In the government investment, central government directly provided 1.18 trillion, accounting for $29.5 \%$ of the whole investment, and the rest was allocated from provincial, local governments ${ }^{3}$. A loosening of monetary policy provided banks enough liquidity and credit to support investment. To be specific, by cutting the benchmark interest rate, deposit reserve ratio and abolishing credit constraints of the commercial banks, the liquidity in financial institutions increased. Meanwhile, the announcement of "RMB 4-trillion stimulus plan" was regarded to send a very powerful signal to the government-controlled banking system that banks should guarantee the growth of the Chinese economy. It was estimated that bank credit grew by 4.7 trillion RMB in 2008, and grew more than double to 9.6 trillion RMB in 2009.

The introduction of the 2008 economic stimulus plan mentioned above clearly shows that the Chinese banking system plays an essential role to fund government fiscal

3 The most of government investment was distributed in transport and power infrastructure $(37.5 \%)$ and post-earthquake construction (25\%). Other items covered affordable housing (10\%), technological innovation and structural adjustment $(9.25 \%)$, rural village infrastructure $(9.25 \%)$, environmental investment $(5.25 \%)$ and health and education $(3.75 \%)$. 
expenditure by following loosed monetary policies and increasing liquidity of credit. Therefore, it is meaningful to examine the implications of these financial policies and fiscal policies on firm-level output, employment and investment based on banking and financial indicators such as banking asset liquidity, capital adequacy ratio, profitability, bad loan ratio, credit supply, government expenditure. Regarding international policies, the effects of Chinese net export and US financial market are also considered.

There is an established literature based on the roles of the financial sector on economic growth. It is widely thought that a healthy financial sector can help allocate capital to the highest valued investments without substantial risk of loss and large transaction costs. It can also reduce the cost of external finance and overcome informational asymmetries, allowing firms to partake in worthwhile investment opportunities and more easily to reduce investment in liquid but unproductive assets (Schumpeter, 1912; Greenwood and Jovanovic, 1990; Levine, 1997). Focusing on whether the banking system can efficiently reallocate capital and fasten economic growth, Hasan et al. (2009) find that an improvement in bank efficiency spurs five times more regional growth than does an identical increase in the quantity of credit. Koetter and Wedow (2010) show that most finance-growth studies approximate the size of the financial systems rather than the quality of intermediation to explain economic growth differentials. They find the bank's intermediation quality estimated by bank-specific efficiency has a significantly positive effect on growth. Especially, Bernanke (1983) highlights the roles the quality of credit 
intermediation plays in the Great Depression to help to explain a slow recovery of the 1930s. Chang et al. (2010) or Zhang et al. (2012) have also focused on the positive relationship between financial development, healthy banking system, and economic growth in China.

Considering the casual link with financial development and economic growth, Love (2003) finds that financial development reduces the reliance of corporate investments on internal funds, thus promoting capital accumulation and growth. Love and Zicchino (2006) uses firm-level data to demonstrate how the link between finance and growth operates on the level of the firm and find financial development has an immediate effect on efficient allocation of capital via investment. Wang (2014) uses the data of ASEAN's 5 countries to explore a direct impact on the level of corporate investments and an indirect impact through alleviating external financing constraints from financial development. It is thought that investment is an essential link connecting financial development and economic growth. In the case of China, Lang et al. (1996) and Chen et al. (2011) observe that optimal bank lending reinforces firms' investment efficiency, while politically based soft lending may bias firms' behavior with regard to investment decisions. Furthermore, Fama and French (1998) and Chen et al. (2009) find that firms' investment decisions significantly influence firm performance because the gains from investments enhance firm profitability.

Employment is also an important connection with financial development, investment and economic growth. It is thought that the credit supply growth can incentivize the firms 
to invest more, expand their businesses and enlarge size. The decrease in the cost of external finance could also result in investment growth and it allows firms to hire more employees due to the complementariness between labor and capital. In the corresponding empirical literature, Garmaise (2008) argues that the cost and availability of external finance have ambiguous effects on employment. On the one hand, easing financing constraints may allow firms to optimally substitute capital for labor by investing in more capital-intensive technologies and decrease employment; while on the other hand, a decrease in the cost of external finance will increase firm-level investment. With the growth of the investment and complement of labor and capital, the demand for labor goes up. Pagano and Pica (2012) use the size of the credit market as a proxy for financial development and suggest that the labor requires financing and a more efficient credit market increases employment even if investment levels remain constant. Chodorow-Reich (2014) concludes that the predicted change in employment varies by about 5 percentage points depending on the health of its lenders. The frictions can account for about one-third to one-half of the decline in employment at small and medium firms in the 2007-2009 crisis.

In the empirical investigation of the effect of the 2008 Chinese economic stimulus plan on the economic recovery, Wen and $\mathrm{Wu}$ (2014) show that implementation of the Chinese stimulus plan is further aided by the soaring fixed asset investment made by Chinese state-owned enterprises (SOE). The Chinese state-owned banks vigorously expanded their 
lending as Chinese central bank relaxed the lending constraints, and SOEs greatly raised their average leverage ratio. Ouyang and Peng (2015) use the treatment-effect estimation on the effects of the 2008 economic stimulus package of China. The results show that the stimulus had a temporary boost in economic activities for about two years. Liu et al. (2018) use firm-level data to investigate the results of economic stimulus package in China and find that state-owned enterprises (SOE) receive more bank loans and invest more than non-SOEs. However, state-owned enterprises (SOE) have weaker relationships between bank loans and firm profitability and between investment expenditure and investment opportunities than non-SOEs.

The roles played by a healthy banking system in the economic growth, employment and investment in economic recovery cannot be neglected. Besides, the financial and fiscal polices incentivize the Chinese firms in the short term and tend to support the state-owned enterprises (SOE). This paper also contributes to further exploring interaction of output, employment and investment on the effects of Chinese financial and fiscal polices by using firm-level data, which helps to build the causal link with financial development and economic growth in the Chinese case.

Many firm characteristics have been shown to play roles in firm credit constraints. Regarding the size of the firm, the literature has shown that small firms have less access to external finance and are more constrained in their internal financing, both in the developing and developed countries (Berger and Udell, 1998; Galindo and Schiantarelli, 
2003). Schiffer and Weder (2001) show that small firms consistently report higher financing obstacles than medium-size or large firms. Beck et al. (2006) observe that size, age and ownership are the most reliable predictors on the firms' financing obstacles. Drakos and Giannakopoulos (2011) find that firms with large employment size experience a large decline in credit rationing probability since employment size could be a signal for firms' ability to repay the loan, implying that size has a detrimental effect on the likelihood of credit constraining. Besides, Kaplan and Zingales (1997), Whited and Wu (2006) and Hadlock and Pierce (2010) employ combinations of observable firm characteristics to measure financial constraints firms face, such as size, age, or leverage.

In the related literature, Modigliani and Miller (1958) have suggested that both firm value and investment decisions are strongly affected by their capital structure in imperfect capital markets. Myers and Majluf (1984) and Jensen and Meckling (1976) show that the external investors ask firms a higher price on the new debt capital due to firms' hidden information and opportunistic behavior. From asymmetric information aspect, according to Stiglitz and Weiss (1981), high liability ratios show that firms have good investments with higher returns compared to the interest rate, which offers a signal to remove the asymmetric information in the loan market and explain the existence of limited access to credit. Jensen (1986) claims that external debt can be considered as an effective way to reduce the agency cost problems that may lead to the underperformance of firms. In these circumstances, resorting to external financiers may provide managers the right incentives 
to avoid cash wasting policies and thus finally result in better firm performances. Huynh and Petrunia (2010) also find that there is a positive and nonlinear relationship between leverage and firm's growth by using listed and unlisted Canadian manufacturing firms; however, high leverage may lead to low growth due to costly new debt and increase the financing constraints (McConnell and Servaes, 1995; Lang et al., 1996; Aivazian et al., 2005).

Regarding the firm profitability for financial constraints, Whited and $\mathrm{Wu}$ (2006) and Drakos and Giannakopoulos (2011) suggest that firms with higher sales growth and higher profitability are less likely to be credit constrained. Similarly, Campello et al. (2010) and Lin et al. (2011) find that firm profitability, sales growth and cash flow over assets are an important consideration for banks to make loan, especially in the financial crisis. In the case of China, Cull and Xu (2003) use the Chinese state-owned enterprises (SOE) data and find bank finance is positively linked to SOE profitability and reforms but this association is not strong. Firth et al. (2009) find that a firm's profitability is used as a criterion in granting loans and in determining loan size by using survey data in China.

In the ownership aspect, Faccio et al. (2006), Claessens et al. (2008) and Faccio (2010) show that politically-connected firms are more likely to be bailed out in the form of more access to bank loans when they face financial difficulties compared to similar but non-politically connected firms. In the case of China, Chan et al. (2012) find that politically-connected firms display no financing constraints, whereas firms without 
political connection experience significant constraints. Huang (2008) shows that although private Chinese firms that have suffered from the allocation of credit are in a better position since 1998, credit constraints are still present. Poncet et al. (2010) find that private firms face the highest degree of financial constraints, whereas state-owned enterprises do not experience any financial constraint; in China, credit constraints for private firms are shown to be reinforced when the presence of state-owned firms is strong.

Regarding the sector heterogeneity, financial development has been shown to have distinct effects on different industries in the corresponding literature. It is shown that financial development can meet the funding needs of certain industries and promote development through supporting corporate innovation, new technology application and upgrading the technological level. For instance, Kletzer and Bardhan (1987) show that low credit constraints could satisfy the need for external financing and thus contribute to the growth of related industries. Rajan and Zingales (1998) use industry-level data and find that the development of the financial system directly promotes industrial growth through reducing the cost of external financing to financially dependent firms. Wurgler (2000) uses the data of 65 countries and finds that well-developed financial markets help improve the efficiency of capital allocation, allow for the growth of the industry to invest more capital and promote the optimization of industrial structure. This strongly supports the significance of the financial development on the growth of the industries. 
Within this literature, I find that a healthy banking system can affect the firm-level output, employment and investment. Since firms with different size, liability ratio, profitability and ownership face different financing constraints, by using firm-level Chinese data, I investigate which firms have benefited more from the Chinese banking system and 2008 economic stimulus plan from the Great Recession to $2014 .^{4}$

\subsection{Empirical methodology and data}

\subsubsection{Economic channels and regression models}

I would like to capture the transmission channels of the Chinese banking system on the Chinese economy given in Figure 2.1. In particular, credit supply in the banking system depends on the financial policies as well as the health of the banking system based on the ratios such as liquidity, capital adequate ratio, profitability and bad loan ratio. Furthermore, bank credit supply affects the firm-level output, employment and investment. Firms are also influenced by fiscal policies and external economic factors, such as net export and US financial market performance.

In the transmission channels in Figure 2.1, I think firm output, employment and investment interacts with each other. Specifically, the increase in employment and investment contributes to output growth; the increased output reversely lead to the growth of employment and investment. Meanwhile, employment and investment might have the

\footnotetext{
${ }^{4}$ I do not use age to categorize firms, since all the firms are public listed.
} 
substitution (negative) or complement (positive) relationships. Second, I hypothesize that healthy banking system, credit supply, government expenditure and external economic factors could influence these three firm-level variables. Specifically, banking indicators, government expenditure and external economic factors affect firm output by its demand side. These variables also affect firm output by influencing employment and investment. Therefore, I consider firm output, employment and investment as endogenous variables and banking indicators, the government expenditure and external economic factors as exdogenous variables 5 .

Figure 2.1 Transmission channels of money, credit and banking system in the economy

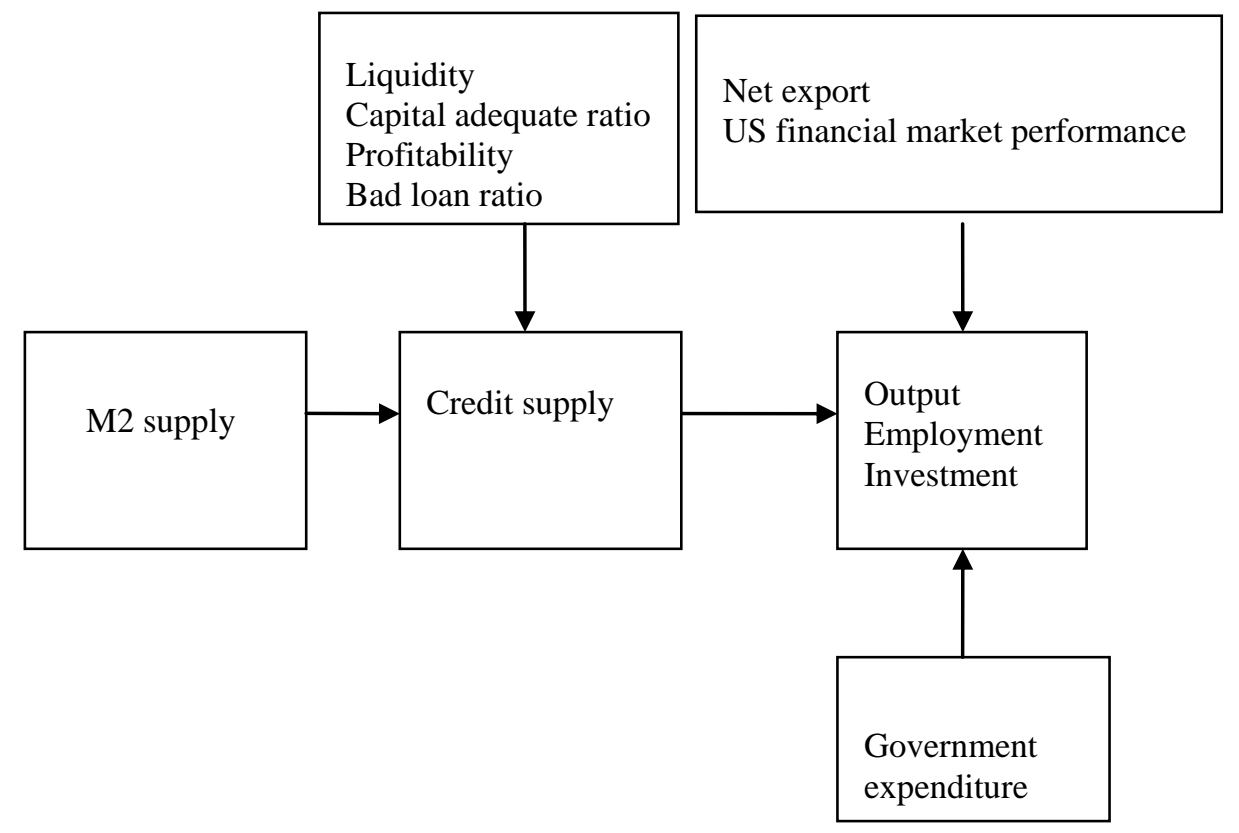

In order to capture such transmission channels in Figure 2.1, my empirical strategy is to use the panel VAR (vector autoregression) at the firm level to estimate the effects of the

${ }^{5}$ Since the sample I use only covers the public listed companies, which occupies the small portion of the whole economy, I do not think that their activities can drive the change of financial and fiscal policies. 
banking system, the government expenditure and external economic factors on the firm output, employment and investment. ${ }^{6}$ The advantage of panel VAR lies that it can examine the interactions among firm output, employment and investment that will be independent of any endogeneity problem. Simultaneously, the panel VAR explores the roles of other exogenous variables. Therefore, I use the panel VAR to estimate my system of dynamic panel models. The system of dynamic panel models is shown as:

$$
\begin{aligned}
& \text { OUTPUT }_{i t}=\sum_{j-1}^{k} \alpha_{j}^{o, 1} \text { OUTPUT }_{i t-j}+\sum_{j-1}^{k} \alpha_{j}^{o, 2} E M P_{i t-j}+\sum_{j-1}^{k} \alpha_{j}^{o, 3} I N V E S T_{i t-j}+b_{1}^{o} H E A_{t-1}+b_{2}^{o} L_{O A N} \\
& +b_{3}^{o} \text { SPEN }_{t-1}+b_{4}^{o} \operatorname{TRADE}_{t-1}+b_{5}^{o} \operatorname{STOCK}_{t-1}+\alpha_{i}^{o}+\varepsilon_{i t}^{o} \\
& E M P_{i t}=\sum_{j-1}^{k} \alpha_{j}^{o, 1} \operatorname{OUTPUT}_{i t-j}+\sum_{j-1}^{k} \alpha_{j}^{e, 2} E M P_{i t-j}+\sum_{j-1}^{k} \alpha_{j}^{e, 3} I N V E S T_{i t-j}+b_{1}^{e} H E A_{t-1}+b_{2}^{e} L_{\text {OAN }} \\
& +b_{3}^{e} \operatorname{SPEN}_{t-1}+b_{4}^{e} \operatorname{TRADE}_{t-1}+b_{5}^{e} \text { STOCK }_{t-1}+\alpha_{i}^{e}+\varepsilon_{i t}^{e} \\
& \operatorname{INVEST}_{i t}=\sum_{j-1}^{k} \alpha_{j}^{i, 1} \operatorname{OUTPUT}_{i t-j}+\sum_{j-1}^{k} \alpha_{j}^{i, 2} \operatorname{EMP}_{i t-j}+\sum_{j-1}^{k} \alpha_{j}^{i, 3} \operatorname{INVEST}_{i t-j}+b_{1}^{i} H_{E A_{t-1}}+b_{2}^{i} \operatorname{LOAN}_{t-1} \\
& +b_{3}^{i} \operatorname{SPEN}_{t-1}+b_{4}^{i} \operatorname{TRADE}_{t-1}+b_{5}^{i} \operatorname{STOCK}_{t-1}+\alpha_{i}^{i}+\varepsilon_{i t}^{i}
\end{aligned}
$$

where OUTPUT refers to log firm output, EMP refers to log firm employment, INVEST refers to $\log$ firm investment; together with firm fixed effects $i$ that are fixed across time periods (in order to control for firm-specific characteristics), these are the only firm-level indicators that I consider in the benchmark case. In my heterogeneity tests, I consider the very same regression framework for alternative firm size, liability ratio, profitability, and ownership as well as 13 different industries in my sample; such an investigation is important to capture any possible nonlinearity within my empirical framework. The

\footnotetext{
${ }^{6}$ The Stata package I use to estimate the panel VAR model is from Abrigo and Love (2015).
} 
remaining indicators (that I discuss in details, below) are common across firms and have been included in the analysis in order to investigate the effects of the banking system, government expenditure, Chinese net export and US financial market performance on the firms. ${ }^{7}$

In the banking system, regarding the indicators of a healthy banking system, $H E A$ means the banking health ratio. It is built through the factor analysis by using banking asset liquidity $(L I Q)$, capital adequacy ratio $(C A P T)$, profitability $(P R O F)$ and bad loan ratio $(B A D)$. These variables are in line with the CAMELS rating system, which covers capital adequacy, assets, management capability, earnings, liquidity and sensitivity; I also consider the Basel II, which covers capital requirements, leverage ratio and liquidity requirements. Correspondingly, Bernanke (1983), Diamond and Rajan (2011), and Caballero and Simsek (2013) show liquidity, insolvency, and the prevalence of bank failures matter and can deepen economic crises or slow recovery. Jin et al. (2011) show that nonperforming loans, loan loss provisions help determine the prevalence of bank failures. Regarding the bank credit, $L O A N$ refers to credit supply.

On top of these variables, SPEN is the government expenditure capturing the direct effects of fiscal policies. Considering the external economic influences, I employ the Chinese net export (TRADE) and US stock market performance (STOCK). It is important

${ }^{7}$ In line with results from moment and model selection criteria (MMSC) (Andrews and Lu, 2001), I set the number of lags $\mathrm{k}$ for output, employment and investment equal to three in order to maximize the statistics. The panel fixed-effects are removed by using the Helmert transformation (known as forward orthogonal deviation) (Arellano and Bover, 1995). 
to emphasize that the banking/financial indicators, government expenditure and external economic factors are all included with their first lags in order to avoid any endogeneity problem.

Table 2.1 Variables and their meanings

\begin{tabular}{ccc}
\hline Variable type & Variables & Meanings \\
\hline Bank credit & LOAN & Credit supply \\
\hline & $L I Q$ & Liquidity \\
Healthy banking system & $C A P T$ & Capital adequacy ratio \\
& $P R O F$ & Profitability \\
& $B A D$ & Bad loan ratio \\
\hline Government fiscal policy & $S P E N$ & Government expenditure \\
\hline \multirow{2}{*}{ External economic factors } & $T R A D E$ & Net export \\
& $S T O C K$ & US stock market performance \\
\hline
\end{tabular}

\subsubsection{Data}

The data are collected from Wind (A Chinese data services provider) and Chinese National Bureau of Statistics (i.e., both firm-level data and nationwide statistics). I collect US financial market performance data from Federal Reserve Bank of St. Louis. I select 1535 firms from all the public listed firms (about 3200 firms) in the Chinese A-share stock market (Shanghai and Shenzheng Stock Exchanges) to keep strongly balanced panel. I use firm revenue to reflect firm output, number of firm employees to reflect firm employment and net capital expenditure to reflect firm investment ${ }^{8}$. In my heterogeneity tests, I also consider other firm-level data, namely firm asset, asset-liability ratio, return on equity

\footnotetext{
${ }^{8}$ I use net capital expenditure (cash payments for fixed assets, intangible assets, and other long-term assets less cash receipts from selling these assets and depreciation) to proxy firm investment. Since some values of net capital expenditure are negative, I use linear transformation to make all the values positive.
} 
(profitability) and ownership. Nationwide variables regarding healthy banking ratio, bank credit, government expenditure, Chinese net export and US financial market performance are given in Table 2.1 .

Specifically, I use loan/GDP to reflect credit supply $(L O A N)$, return on equity of Chinese banking system to reflect profitability $(P R O F)$. I also use growth of government expenditure to reflect government expenditure (EXPE), net export/GDP to measure net export (TRADE) and S\&P 500 index returns to measure US financial market performance (STOCK). Considering firms with different characteristics, I split the firms in line with size, liability, profitability and ownership from Panel A to Panel D. I find that firms with large size, high liability and high profitability have much larger output, employment and investment than the other types of firms with medium and small features, especially for investment. Panel D in Table 2.2 depicts that output (452.089), employment (5588.563) and investment (13.456) in state-owned firms are much higher compared to private firms; the difference between state-owned and private firms is about 7 times in output and 1.6 times in employment and even about 10 times in investment ${ }^{9}$. These present the huge difference for firms with different characteristics, especially for their investment.

Since different industrial sectors may obtain different credit supports by Chinese banks, I also split the firms in line with the Industry Classification Guideline made by China Securities Regulatory Commission (CSRC). The list of 13 industry sectors in this

9 The state-owned firms include central state-owned firms and local state-owned firms. Some firms belong to other types of ownerships, such as foreign-owned firms and collective firms. Since the number of foreign-owned firms and collective firms is very few, I do not explore them. 
paper is given in Panel E in Table 2.2 which also provides descriptive statistics of the corresponding firms. As is evident, there are three industries that have the highest share in output, employment and investment; these are Mining Industry (MIN), Financial \& Insurance Industry (FIN), and Construction Industry (CON). Therefore, I think there is a good amount of heterogeneity across firms due to size, liability, profitability, ownership and industry.

The data I use in this paper are quarterly from 2008 to 2014 and cover both firm-level data and nationwide statistics. The period selection considers the policy regime change, since the Chinese government carried out a new 10 trillion stimulus in 2015, and banking system indicators changed extensively. In order to have a healthy empirical investigation that is robust to outliers, I apply the Hodrick-Prescott filter $(\lambda=1600)$ to delete time trend and seasonality; I also winsorize the highest $2.5 \%$ and the lowest $2.5 \%$ of the firm-level observations in output, employment and investment, since some Chinese firms manage earnings in the different quarters, especially in the fourth quarter in one year.

As is evident in Figure 2.2, this is a perfect period for my investigation regarding the effects of the Chinese banking system on both the drop and the recovery of the Chinese economy. In particular, from the first quarter of 2008 to the third quarter of 2009, GDP annual growth rate drops from $11.3 \%$ to $8.2 \%$, and it recovers through the last quarter of 2010 with a growth rate of $10.4 \%$, which is followed by movement of Chinese net export. As is evident in Figure 2.2, the employment growth drops from 2.5\% in the first quarter of 
2008 to $1 \%$ in the third quarter of 2009 . However, the fixed asset investment growth rate rises from about $25.9 \%$ through the beginning of 2008 to about $30.5 \%$ in the last quarter of 2009. It supports that "RMB 4-trillion stimulus plan" stimulates Chinese economy through greatly promoting fix asset investment. After 2010, Chinese GDP growth slows down from 10\% in 2011 to $7 \%$ in 2014 while the fixed asset growth also continues decreasing, which reveals the temporary effects of Chinese economic stimulus plan for the Chinese economic growth. However, the employment continues to grow around 7\% per year from 2011 to $2014 .^{10}$

${ }^{10}$ The employment and fixed asset investment are collected in the Chinese urban regions and eliminate the outliers. 
Table 2.2 Descriptive statistics of firms' characteristics

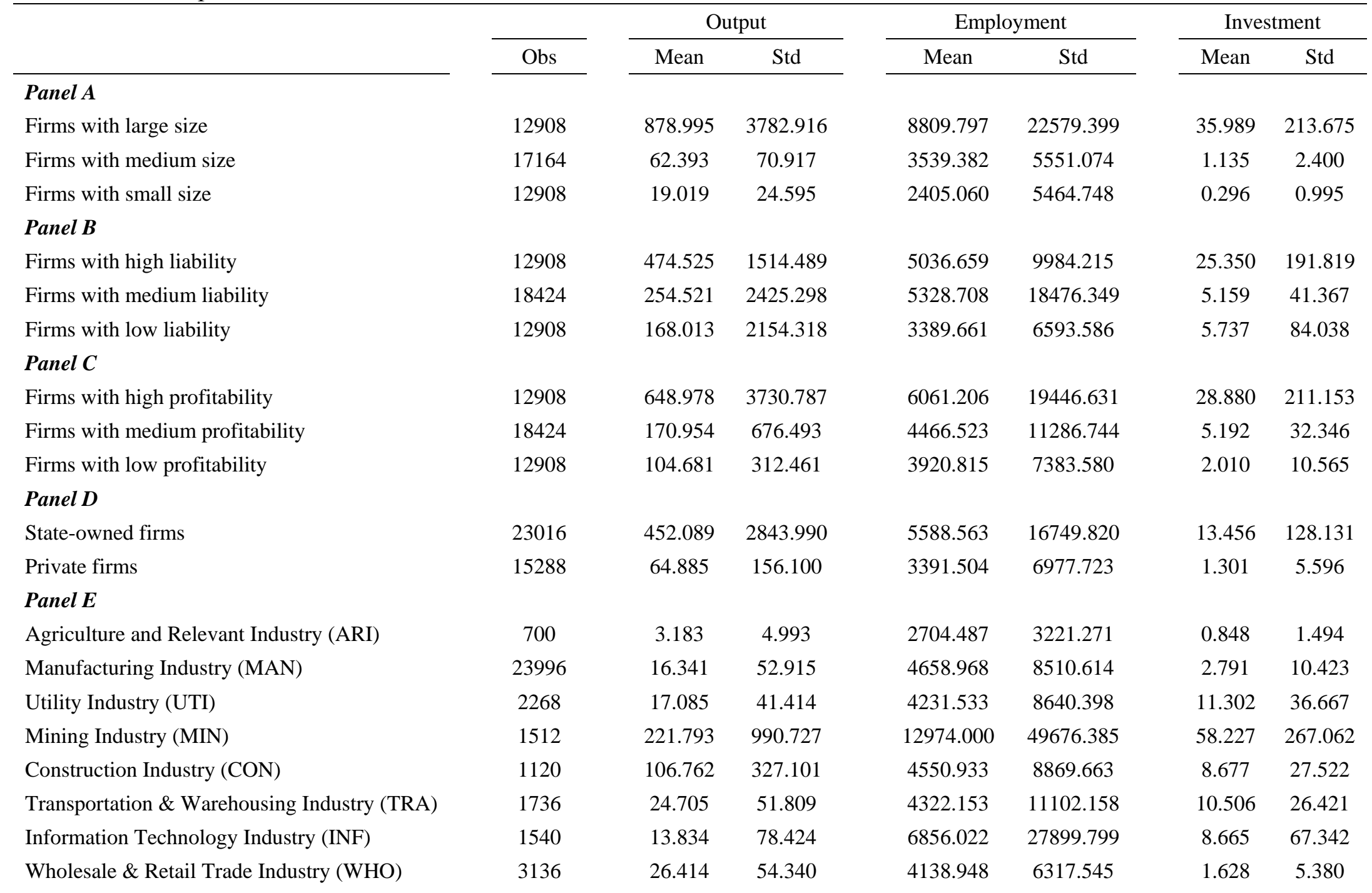




\begin{tabular}{lccccccc} 
Financial \& Insurance Industry (FIN) & 1092 & 172.498 & 326.779 & 6640.779 & 11249.399 & 230.149 & 620.057 \\
Real Estate Industry (EST) & 3248 & 9.748 & 34.259 & 3639.997 & 8478.039 & 1.577 & 7.489 \\
Social Service Industry (SOC) & 1568 & 4.419 & 10.770 & 2930.137 & 3898.593 & 1.857 & 7.586 \\
Communication \& Culture Industry (COM) & 500 & 3.886 & 4.963 & 2499.175 & 3075.594 & 1.153 & 2.625 \\
Conglomerate Industry (CONG) & 560 & 4.034 & 3.822 & 2751.742 & 2352.449 & 0.477 & 2.303 \\
\hline
\end{tabular}

Notes: The industry classification on the public listed firms is based on the Industry Classification Guideline in China Securities Regulatory Commission (CSRC). The unit of output is 10 million RMB and the unit of investment is 100 million RMB. 
Figure 2.2 The trend of the macroeconomic variables from 2008 to 2014
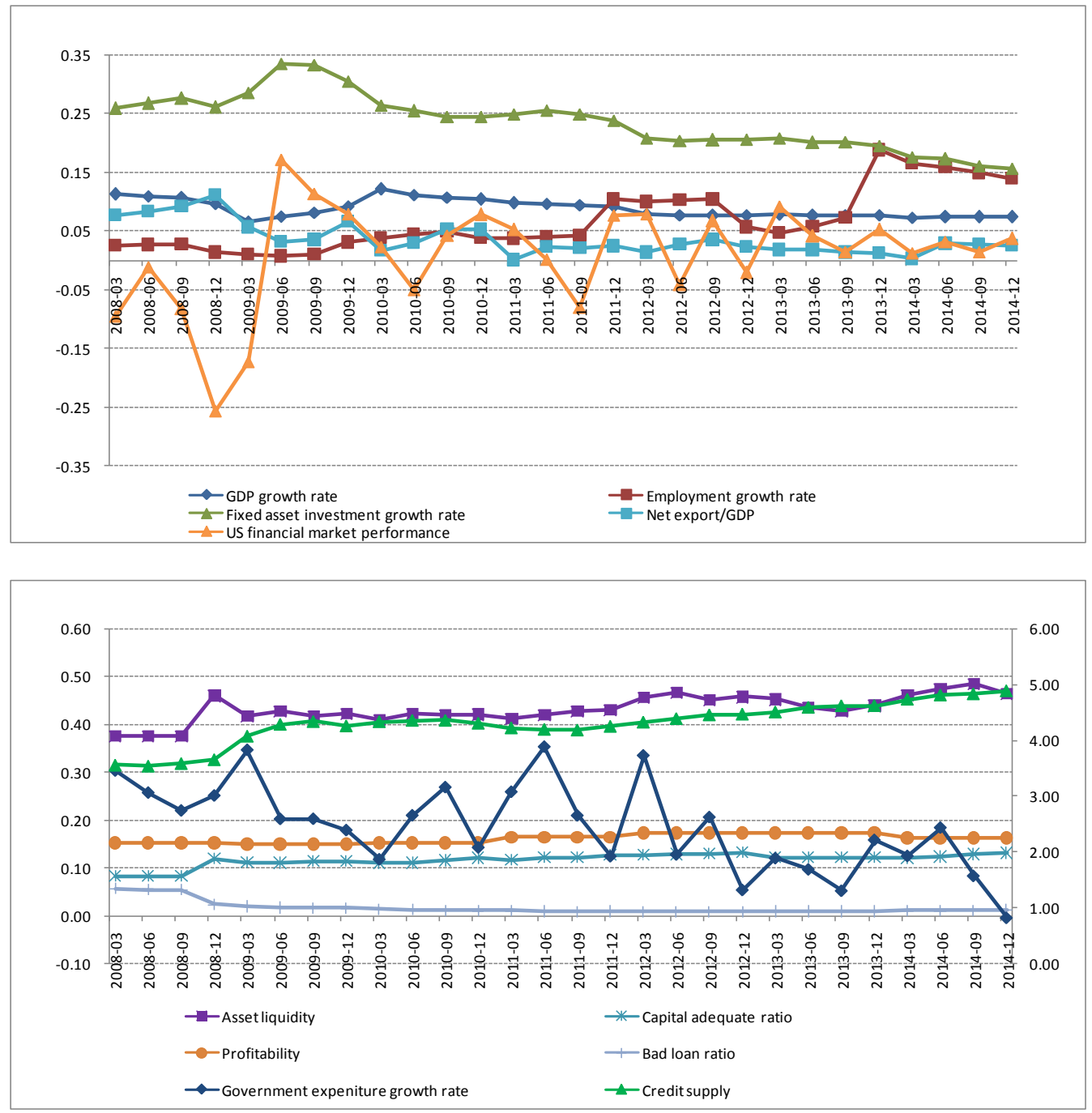

Regarding the relationship between Chinese economic activity and the banking system in Figure 2.2, the recovery in GDP coincides with the increase in credit supply, capital adequacy ratio, profitability and with the reduction in bad loan ratio. It is implied that the improvement of the Chinese economic activity coincides with the improvement in the banking performance. The growth of government expenditure is also related to the 
recovery of Chinese GDP in Figure 2.2, showing evidence of the importance of fiscal policy.

Table 2.3 Correlation coefficients of credit and banking health indicators

\begin{tabular}{|c|c|c|c|c|c|}
\hline & $L I Q$ & $C A P T$ & $B A D$ & PROF & $L O A N$ \\
\hline$L I Q$ & 1 & & & & \\
\hline$C A P T$ & $0.742^{* * * *}$ & 1 & & & \\
\hline$B A D$ & $-0.492^{* * *}$ & $-0.792^{* * *}$ & 1 & & \\
\hline PROF & $-0.072^{* * *}$ & $0.043^{* * *}$ & $0.156^{* * * *}$ & 1 & \\
\hline$L O A N$ & 0.005 & $-0.130^{* * * *}$ & $-0.246^{* * *}$ & $-0.094^{* * *}$ & 1 \\
\hline
\end{tabular}

In order to understand better the transmission channels of the banking system and credit on the Chinese economy, I also calculate their correlation coefficients among the variables of banking system and credit in Table 2.3 . As is evident, liquidity $(L I Q)$, capital adequacy ratio $(C A P T)$, profitability $(P R O F)$ and bad loan ratio $(B A D)$ have significant correlation coefficients with credit supply $(L O A N)$. It is implied that a healthy banking system is significantly correlated with the growth of credit supply. In details, bad loan ratio and profitability have a significant negative impact on the credit supply, meaning that higher bad loan ratio and profitability make firms act in a more prudent way regarding credit supply. Similarly, higher capital adequacy ratio can decrease the credit supply since banks have to reduce credit when they have enough total bank reserve. Nevertheless, a formal analysis is required in order to see the interaction between these variables and firm-level indicators, which is pursued next. 


\subsection{Empirical results}

\subsubsection{Static analysis}

This section provides the results based on the panel VAR model. While the first subsection depicts the results of the benchmark case which considers the linear relationship between the banking indicators and firm-level output, employment, and investment, the second subsection depicts the results based on possible nonlinearities in this relationship based on firm characteristics for heterogeneity. ${ }^{11}$

I employ the panel VAR model to analyze the Chinese banking system's roles on the recovery of firm output, employment and investment. The results are given in Table 2.4. Since liquidity, capital adequate ratio, profitability and bad loan ratio (see Table 2.3) have strong correlations with each other, I employ a factor analysis to construct one index titled banking health ratio $(H E A)$ in the regression model. ${ }^{12}$ Table 2.4 shows that firm-level output, employment and investment have a significant interaction. While firm investment has a weak positive effect on output, it has a significant positive influence on employment and then increases firm output. Besides, the increased output reversely promotes the growth of employment and investment, which forms the positive interaction with these three firm variables.

${ }^{11}$ I also test the stability condition and Granger causality among the variables in the equation. I find that the panel VAR satisfies the stable condition and the variables in the RHS are Granger-causing variables.

12 In the factor analysis, the estimated weights on liquidity, capital adequacy ratio, profitability ratio and bad loan ratio are $0.835,0.952,-0.112$ and -0.866 , respectively. 
Regarding the roles of the banking system, I find that banking health ratio enters all three regressions with a positive expected sign. It is evident that credit supply has significant positive impacts on the firm output. Government expenditure also has positive and significant effects on output. The results are very similar regarding the positive effects of banking health ratio, credit supply and government expenditure on firm employment and investment. It means that banking health, credit supply and government expenditure are beneficial for the growth of firm-level output, employment and investment. Further, I observe that the effects of credit supply and government expenditure on the investment are much larger than output, which shows the main stimulus from financial and fiscal polices lie on the investment. Besides, Chinese net export and US stock market performance have significant positive influences on the output, employment and investment, except the insignificant influences of US financial market performance on the output.

Therefore, there is strong evidence for both bank credit and a healthy banking system to be effective in the promotion of firm-level output, employment and investment. Together with the significance of government expenditure in all regressions, it is implied that both the "RMB 4-trillion stimulus plan" and the bank credit growth of about RMB 14.6 trillion have been effective for the recovery of Chinese firms, especially for investment (Liu et al., 2018). The results are in line with studies such as by Bernanke's (1983), Hasan et al. (2009) and Koetter and Wedow (2010), who show the importance of banking health conditions on the economic recovery. 
Table 2.4 Results on firm-level variables: Linear model

\begin{tabular}{|c|c|c|c|c|c|c|}
\hline & \multicolumn{2}{|c|}{ Output } & \multicolumn{2}{|c|}{ Employment } & \multicolumn{2}{|c|}{ Investment } \\
\hline & (1) & (2) & (1) & (2) & (1) & (2) \\
\hline \multirow[t]{2}{*}{ OUTPUT(-1) } & $0.182^{* * *}$ & $0.178^{* * * *}$ & $0.016^{* * *}$ & $0.016^{* * * *}$ & $0.021^{* * * *}$ & $0.020^{* * *}$ \\
\hline & $(0.044)$ & $(0.044)$ & $(0.005)$ & $(0.005)$ & $(0.003)$ & $(0.003)$ \\
\hline \multirow[t]{2}{*}{$E M P(-1)$} & $0.116^{* * * *}$ & $0.120^{* * * *}$ & $0.833^{\text {**** }}$ & $0.835^{* * *}$ & $-0.139^{* * *}$ & $-0.132^{* * *}$ \\
\hline & (0.044) & (0.044) & $(0.025)$ & $(0.025)$ & $(0.015)$ & $(0.015)$ \\
\hline \multirow[t]{2}{*}{$\operatorname{INVEST}(-1)$} & $0.019^{*}$ & 0.017 & $0.019^{* * * *}$ & $0.018^{* * *}$ & $0.384^{* * *}$ & $0.385^{* * *}$ \\
\hline & $(0.011)$ & $(0.011)$ & $(0.003)$ & $(0.003)$ & $(0.010)$ & $(0.010)$ \\
\hline \multirow[t]{2}{*}{$H E A(-1)$} & & $0.048^{* * * *}$ & & $0.006^{* * * *}$ & & $0.051^{* * *}$ \\
\hline & & $(0.004)$ & & $(0.001)$ & & $(0.002)$ \\
\hline \multirow[t]{2}{*}{$\operatorname{LOAN}(-1)$} & $0.108^{* * *}$ & $0.106^{* * * *}$ & -0.0001 & $0.017^{* * *}$ & $0.266^{* * * *}$ & $0.322^{* * *}$ \\
\hline & $(0.017)$ & $(0.021)$ & $(0.003)$ & $(0.004)$ & $(0.007)$ & (0.008) \\
\hline \multirow[t]{2}{*}{ SPEN(-1) } & $0.210^{* * * *}$ & $0.356^{* * * *}$ & $0.037^{* * * *}$ & $0.041^{* * * *}$ & $0.395^{* * * *}$ & $0.469^{* * *}$ \\
\hline & $(0.050)$ & $(0.053)$ & $(0.013)$ & $(0.014)$ & $(0.029)$ & $(0.030)$ \\
\hline \multirow[t]{2}{*}{$\operatorname{TRADE}(-1)$} & & $0.638^{* *}$ & & $0.827^{* * *}$ & & $2.417^{* * *}$ \\
\hline & & $(0.315)$ & & $(0.101)$ & & $(0.179)$ \\
\hline \multirow[t]{2}{*}{ STOCK $(-1)$} & & 0.031 & & $0.029^{* *}$ & & $-0.130^{* * * *}$ \\
\hline & & $(0.044)$ & & $(0.013)$ & & $(0.029)$ \\
\hline Observation & 36840 & 36840 & 36840 & 36840 & 36840 & 36840 \\
\hline$N$ & 1535 & 1535 & 1535 & 1535 & 1535 & 1535 \\
\hline
\end{tabular}

Note: ${ }^{* * * * *}$ and ${ }^{*}$ show the significance at the level of $1 \%, 5 \%$ and $10 \%$, respectively. The standard error is estimated by white robust covariance. The model is estimated in first differences with third lagged instruments. The sample covers all the 13 industries and the sample period is from 2008 to 2014. All the variables are removed by trend and seasonality. I do not report the influences of second and third lagged output, employment and investment because of the space limitations.

Although the results provided above depict the linear relationship between banking indicators and firm-level output, employment and investment, their relationship can also be nonlinear because of the financial constraints for different firm-level characteristics such as firm size, liability, profitability, ownership or the industry that the firm belongs to. In this subsection, I investigate such possible nonlinearities in details.

Earlier studies have found evidence suggesting firm size affects the firm's access to credit, including Berger and Udell (1998), Schiffer and Weder (2001), Galindo and 
Schiantarelli (2003), Beck et al. (2006) and Drakos and Giannakopoulos (2011). In order to connect my results to such studies, I split the firms in my sample into three groups, namely large size, medium size and small size. ${ }^{13}$ By using these groups, I run the Panel VAR model once again and obtain the results in Table 2.5. I find that firm investment does not have a significant positive impact on output while investment positively affects employment and then promote the output growth for medium- and small-size firms. On the other hand, the increased output reversely has a significant positive role on employment and investment for large-size firms. The positive role of investment on output is larger for medium- and small-size firms, which shows that large-size firms might have lower investment efficiency. The low reverse effects of output on investment for medium- and small-size firms show the difficulty to support investment through internal financing.

Regarding the roles of banking system and credit indicators on firm output, employment and investment, it is evident that the banking health ratio and credit supply have positive and significant effects on firm output for all levels of firm size, with their bigger impacts on the medium- and small-size firms. Similar larger positive impacts are found in medium- and small-size firms in employment. However, in the firm investment, I find that the banking health ratio and credit supply have larger impacts on the firm investment in the large- and medium-size firms. The finding supports the argument that small-size firms have large financial constraints so that they can not invest enough. The

${ }^{13}$ I divide all the firms with the highest $30 \%$, the middle $40 \%$ and the lowest $30 \%$ and define the highest $30 \%$ as the firms with large size, the middle $40 \%$ as the firms with medium size and the lowest $30 \%$ as the firms with small size. 
results also reveal the low investment efficiency for larger Chinese firms since the roles of the banking system and credit indicators on the output are smaller in large-size firms than medium- and small-size firms. I think that the low investment efficiency of state-owned firms may be a deep reason because they have much larger size (see Table 2.2).

Furthermore, it is also evident that government expenditure has a positive impact on firm output, employment and investment for all levels of firm size. The positive influences are large in the investment of large-size firms but the positive influences are small in the output while the medium- and small-size firms meet the opposite situations. This finding also presents the low investment efficiency for large-size firms. Furthermore, net export has positive significant effects on the employment and investment of all level-size firms. The US stock market performance has more significant impacts on the large- and medium-size firms.

The relationship between firms and banks may also depend on the liability ratio of the firms. In particular, high liability ratios show that firms have good investments with higher returns compared to the interest rate, which offers a signal to remove the asymmetric information in the loan market and to increase the access to credit (e.g., see Stiglitz and Weiss, 1981; Jensen, 1986). On the other hand, the positive relationship between high leverage and financing constraints may also harm a firm due to costly new debt (e.g. see McConnell and Servaes, 1995; Lang et al., 1996; Aivazian et al., 2005). In order to 
investigate these alternative impacts, I split the firms in my sample by their liability ratio and run the panel VAR model ${ }^{14}$.

Regarding the interaction of firm-level output, employment and investment, it is evident that investment positively affects employment and then increases output while investment does not have a significant and positive effect on output. Furthermore, I observe that the increased output reversely promotes the growth of employment and investment. The interaction of firm-level output, employment and investment is more significant for the firms with high liability.

The corresponding results are shown in Table 2.6, where banking health ratio, credit supply have their positive effects on firm output, employment and investment. There is also evidence for a nonlinear relationship between the banking indicators and firm output; i.e., while the biggest impact of banking variables for output and investment is on highand medium-liability firms. Regarding government expenditure, the largest impact of government expenditure in output and investment is on large- and medium-liability firms. These results are in line with studies such as by Huynh and Petrunia (2010) who find a positive and nonlinear relationship between leverage and firm's growth by using listed and unlisted Canadian manufacturing firms. Meanwhile, it shows that firms with high liability undertake good investments with higher returns. Nevertheless, the results are not consistent with other studies such as by Lang et al. (1996), McConnell and Servaes (1995)

${ }^{14}$ I divide all the firms with the highest $30 \%$, the middle $40 \%$ and the lowest $30 \%$ and define the highest $30 \%$ as the firms with high liability, the middle $40 \%$ as the firms with medium liability and the lowest $30 \%$ as the firms with low liability. 
or Aivazian et al. (2005) who show that high leverage may lead to low growth due to costly new debt and increases in financing constraints. Furthermore, net export and US stock market performance do not have significant positive impacts on the three groups.

It is thought that firms with higher profitability are less likely to be credit constrained (e.g., see Whited and Wu, 2006; Campello et al., 2010; Drakos and Giannakopoulos, 2011; Lin et al., 2011) and state-owned enterprises (SOE) with high profitability tend to get loans from bank in China (e.g., see Cull and Xu, 2003; Firth et al., 2009). Therefore, to investigate such linkages, I split the firms into three groups in line with their earnings and profitability (ROE), that is, high profitable firms, medium profitable firms and low profitable firms ${ }^{15}$.

Table 2.7 shows that investment has a positive expected effect on employment and then positively affects output while investment has not a positive and significant effect on output. Furthermore, I find that the increased output reversely promotes the growth of employment and investment. Table 2.7 also shows that banking health ratio has more significantly positive effects on the output of medium profitable and low profitable firms. The effects of credit supply are significantly positive on the output of three types of firms. I also find that banking health ratio and credit supply have much larger effects on the employment and investment for high profitable firms. It supports the opinion that the Chinese banking system tends to finance firms with high earnings growth and profitability;

${ }^{15}$ I divide all the firms with the highest $30 \%$, the middle $40 \%$ and the lowest $30 \%$ and define the highest $30 \%$ as the firms with high profitability, the middle $40 \%$ as the firms with medium profitability and the lowest $30 \%$ as the firms with low profitability. 
firms with low earnings and profitability face the financing obstacle and constraints since the effects of banking system on investment of high profitable firms are much larger among the medium and low profitable firms.

The similar finding is also shown in the effects of government expenditure. I observe that government expenditure positively affects all three types of firms. However, the effect of government expenditure on investment is largest in firms with high profitability, which presents these firms can easier obtain the supports from the Chinese government. Furthermore, net export and US financial market performance have more influences on output of low profitable firms and net export has positive and significant effects only on the investment of high and medium profitable firms.

Earlier studies have also shown that ownership of a firm can influence its financial constraints (e.g., see Beck et al., 2006; Poncet et al., 2010; Chan et al., 2012). In China, the banking system is influenced by government and the banks' lending decisions often reflect government-dictated policies rather than commercial judge and sometimes have to finance state-owned enterprises (SOE) which are in losses (e.g., see Cull and Xu, 2003; Allen et al., 2005; Firth et al., 2009; Chen et al., 2013; Liu et al., 2018) Accordingly, I split the firms in line with state ownership and private ownership and run the panel VAR model one more time. 
Table 2.5 Results on firm-level variables: Size

\begin{tabular}{|c|c|c|c|c|c|c|c|c|c|}
\hline & \multicolumn{3}{|c|}{ Output } & \multicolumn{3}{|c|}{ Employment } & \multicolumn{3}{|c|}{ Investment } \\
\hline & Large size & Medium size & Small size & Large size & Medium size & Small size & Large size & Medium size & Small size \\
\hline \multirow[t]{2}{*}{ OUTPUT(-1) } & 0.048 & $0.171^{* * *}$ & $0.245^{* * *}$ & $0.042^{* * *}$ & 0.010 & 0.005 & $0.031^{* * *}$ & -0.007 & 0.001 \\
\hline & $(0.063)$ & $(0.050)$ & $(0.064)$ & $(0.012)$ & $(0.009)$ & $(0.005)$ & $(0.011)$ & $(0.006)$ & $(0.002)$ \\
\hline \multirow[t]{2}{*}{$E M P(-1)$} & 0.012 & $0.133^{* * *}$ & $0.225^{*}$ & $0.769^{* * *}$ & $0.839^{* * * *}$ & $0.910^{* * * *}$ & $-0.163^{* * *}$ & $-0.178^{* * *}$ & $-0.083^{* * *}$ \\
\hline & $(0.051)$ & $(0.047)$ & $(0.117)$ & $(0.052)$ & $(0.026)$ & $(0.034)$ & $(0.030)$ & $(0.025)$ & $(0.014)$ \\
\hline \multirow[t]{2}{*}{$\operatorname{INVEST}(-1)$} & 0.007 & 0.013 & -0.010 & $0.011^{* * *}$ & $0.020^{* * * *}$ & $0.023^{* *}$ & $0.320^{* * * *}$ & $0.423^{* * *}$ & $0.506^{* * *}$ \\
\hline & $(0.015)$ & $(0.011)$ & $(0.037)$ & $(0.004)$ & $(0.005)$ & $(0.010)$ & $(0.014)$ & $(0.013)$ & $(0.018)$ \\
\hline \multirow[t]{2}{*}{$H E A(-1)$} & $0.053^{* * * *}$ & $0.055^{* * *}$ & $0.068^{* * *}$ & $0.016^{* * *}$ & $0.005^{* * *}$ & 0.00002 & $0.144^{* * * *}$ & $0.066^{* * *}$ & $0.025^{* * *}$ \\
\hline & $(0.007)$ & $(0.004)$ & $(0.009)$ & $(0.002)$ & $(0.001)$ & $(0.002)$ & $(0.006)$ & $(0.003)$ & $(0.002)$ \\
\hline \multirow[t]{2}{*}{$\operatorname{LOAN}(-1)$} & $0.216^{* * *}$ & $0.264^{* * *}$ & $0.258^{* * *}$ & $0.042^{* *}$ & $0.029^{* * * *}$ & $0.018^{*}$ & $1.187^{* * * *}$ & $0.497^{* * *}$ & $0.213^{* * *}$ \\
\hline & $(0.060)$ & $(0.046)$ & $(0.088)$ & $(0.017)$ & $(0.010)$ & $(0.010)$ & $(0.052)$ & $(0.025)$ & $(0.017)$ \\
\hline \multirow[t]{2}{*}{$\operatorname{SPEN}(-1)$} & $0.270^{* * *}$ & $0.356^{* * *}$ & $0.466^{* * *}$ & 0.043 & $0.064^{* * *}$ & 0.019 & $1.130^{* * * *}$ & $0.477^{* * * *}$ & $0.223^{* * *}$ \\
\hline & (0.094) & $(0.053)$ & $(0.129)$ & $(0.031)$ & $(0.019)$ & $(0.026)$ & $(0.078)$ & $(0.041)$ & $(0.029)$ \\
\hline \multirow[t]{2}{*}{$T R A D E(-1)$} & -0.173 & -0.116 & 0.231 & $0.947^{* * *}$ & $0.893^{* * *}$ & $0.289^{*}$ & -0.197 & $0.690^{* * * *}$ & $0.282^{*}$ \\
\hline & $(0.514)$ & $(0.311)$ & $(0.583)$ & $(0.197)$ & $(0.123)$ & $(0.150)$ & $(0.428)$ & $(0.209)$ & $(0.145)$ \\
\hline \multirow[t]{2}{*}{$\operatorname{STOCK}(-1)$} & $0.181^{* *}$ & $0.099^{*}$ & 0.035 & 0.036 & $0.059^{* * *}$ & 0.015 & 0.111 & 0.009 & 0.005 \\
\hline & $(0.075)$ & $(0.054)$ & (0.098) & $(0.032)$ & $(0.018)$ & $(0.023)$ & $(0.076)$ & $(0.037)$ & $(0.026)$ \\
\hline Observation & 11064 & 14712 & 11064 & 11064 & 14712 & 11064 & 11064 & 14712 & 11064 \\
\hline$N$ & 461 & 613 & 461 & 461 & 613 & 461 & 461 & 613 & 461 \\
\hline
\end{tabular}

Note: ${ }^{* * * * *}$, and ${ }^{*}$ show the significance at the level of $1 \%, 5 \%$ and $10 \%$, respectively. The standard error is estimated by white robust covariance. The model is estimated in first differences with third lagged instruments. The sample covers all the 13 industries and the sample period is from 2008 to 2014. All the variables are removed by trend and seasonality. I do not report the influences of second and third lagged output, employment and investment because of the space limitations. 
Table 2.6 Results on firm-level variables: Liability

\begin{tabular}{|c|c|c|c|c|c|c|c|c|c|}
\hline & \multicolumn{3}{|c|}{ Output } & \multicolumn{3}{|c|}{ Employment } & \multicolumn{3}{|c|}{ Investment } \\
\hline & $\begin{array}{c}\text { High } \\
\text { liability }\end{array}$ & $\begin{array}{c}\text { Medium } \\
\text { liability }\end{array}$ & Low liability & $\begin{array}{c}\text { High } \\
\text { liability }\end{array}$ & $\begin{array}{c}\text { Medium } \\
\text { liability }\end{array}$ & Low liability & $\begin{array}{c}\text { High } \\
\text { liability }\end{array}$ & $\begin{array}{l}\text { Medium } \\
\text { liability }\end{array}$ & $\begin{array}{c}\text { Low } \\
\text { liability }\end{array}$ \\
\hline \multirow[t]{2}{*}{ OUTPUT(-1) } & $0.264^{* * * *}$ & $0.135^{*}$ & 0.062 & 0.002 & $0.039^{* * * *}$ & $0.012^{* *}$ & $0.008^{* *}$ & $0.015^{*}$ & 0.006 \\
\hline & $(0.072)$ & $(0.076)$ & $(0.057)$ & $(0.007)$ & $(0.010)$ & $(0.006)$ & (0.004) & $(0.008)$ & $(0.006)$ \\
\hline \multirow[t]{2}{*}{$E M P(-1)$} & $0.123^{*}$ & 0.059 & $0.181^{*}$ & $0.808^{* * * *}$ & $0.842^{* * *}$ & $0.844^{* * *}$ & $-0.170^{* * * *}$ & $-0.153^{* * *}$ & $-0.128^{* * *}$ \\
\hline & $(0.077)$ & $(0.054)$ & $(0.093)$ & $(0.057)$ & $(0.028)$ & (0.039) & $(0.024)$ & $(0.027)$ & $(0.026)$ \\
\hline \multirow[t]{2}{*}{ INVEST (-1) } & 0.006 & 0.004 & 0.009 & $0.012^{* *}$ & $0.024^{* * *}$ & $0.009^{*}$ & $0.341^{* * * *}$ & $0.355^{* * *}$ & $0.334^{* * *}$ \\
\hline & $(0.012)$ & $(0.022)$ & $(0.019)$ & $(0.005)$ & $(0.005)$ & $(0.005)$ & $(0.017)$ & $(0.015)$ & $(0.019)$ \\
\hline \multirow[t]{2}{*}{$H E A(-1)$} & $0.075^{* * *}$ & $0.050^{* * *}$ & $0.050^{* * * *}$ & $0.007^{* * *}$ & $0.008^{* * *}$ & $0.005^{* * *}$ & $0.091^{* * *}$ & $0.081^{* * * *}$ & $0.056^{* * * *}$ \\
\hline & $(0.009)$ & $(0.005)$ & $(0.007)$ & $(0.002)$ & $(0.002)$ & $(0.002)$ & $(0.005)$ & (0.004) & $(0.004)$ \\
\hline \multirow[t]{2}{*}{$\operatorname{LOAN}(-1)$} & $0.358^{* * *}$ & $0.225^{* * *}$ & $0.112^{* *}$ & 0.019 & $0.044^{* * *}$ & $0.020^{*}$ & $0.758^{* * *}$ & $0.589^{* * *}$ & $0.455^{* * *}$ \\
\hline & $(0.089)$ & $(0.052)$ & $(0.054)$ & $(0.013)$ & $(0.011)$ & $(0.011)$ & $(0.040)$ & $(0.030)$ & $(0.029)$ \\
\hline \multirow[t]{2}{*}{$\operatorname{SPEN}(-1)$} & $0.507^{* * *}$ & $0.366^{* * *}$ & $0.277^{* * *}$ & 0.033 & $0.062^{* * *}$ & 0.043 & $0.636^{* * *}$ & $0.680^{* * *}$ & $0.397^{* * *}$ \\
\hline & (0.106) & $(0.070)$ & $(0.101)$ & $(0.026)$ & $(0.021)$ & $(0.026)$ & $(0.062)$ & $(0.047)$ & $(0.047)$ \\
\hline \multirow[t]{2}{*}{$T R A D E(-1)$} & 0.476 & -0.507 & 0.331 & $0.769^{* * * *}$ & $0.661^{* * *}$ & $0.706^{* * *}$ & 0.001 & 0.267 & $1.022^{* * * *}$ \\
\hline & $(0.571)$ & $(0.411)$ & $(0.423)$ & $(0.172)$ & $(0.138)$ & $(0.146)$ & $(0.323)$ & $(0.250)$ & $(0.239)$ \\
\hline \multirow[t]{2}{*}{$\operatorname{STOCK}(-1)$} & $0.175^{*}$ & 0.068 & 0.054 & $0.056^{* *}$ & 0.016 & $0.045^{*}$ & 0.044 & 0.034 & 0.033 \\
\hline & $(0.092)$ & $(0.060)$ & $(0.075)$ & $(0.024)$ & $(0.022)$ & $(0.025)$ & $(0.060)$ & $(0.045)$ & (0.044) \\
\hline Observation & 11064 & 14712 & 11064 & 11064 & 14712 & 11064 & 11064 & 14712 & 11064 \\
\hline$N$ & 461 & 613 & 461 & 461 & 613 & 461 & 461 & 613 & 461 \\
\hline
\end{tabular}


Table 2.7 Results on firm-level variables: Profitability

\begin{tabular}{|c|c|c|c|c|c|c|c|c|c|}
\hline & \multicolumn{3}{|c|}{ Output } & \multicolumn{3}{|c|}{ Employment } & \multicolumn{3}{|c|}{ Investment } \\
\hline & $\begin{array}{c}\text { High } \\
\text { profitability }\end{array}$ & $\begin{array}{c}\text { Medium } \\
\text { profitability }\end{array}$ & $\begin{array}{l}\text { Low } \\
\text { profitability }\end{array}$ & $\begin{array}{c}\text { High } \\
\text { profitability }\end{array}$ & $\begin{array}{c}\text { Medium } \\
\text { profitability }\end{array}$ & $\begin{array}{c}\text { Low } \\
\text { profitabilit } \\
\mathrm{y}\end{array}$ & $\begin{array}{c}\text { High } \\
\text { profitabi } \\
\text { lity }\end{array}$ & $\begin{array}{l}\text { Medium } \\
\text { profitabi } \\
\text { lity }\end{array}$ & $\begin{array}{c}\text { Low } \\
\text { profitabi } \\
\text { lity }\end{array}$ \\
\hline \multirow[t]{2}{*}{ OUTPUT(-1) } & $0.175^{* *}$ & $0.163^{* * *}$ & $0.176^{* * *}$ & $0.019^{* *}$ & $0.022^{* * *}$ & 0.010 & 0.003 & $0.024^{* * *}$ & $0.007^{*}$ \\
\hline & $(0.082)$ & $(0.026)$ & $(0.065)$ & $(0.008)$ & $(0.007)$ & $(0.007)$ & $(0.006)$ & $(0.008)$ & $(0.004)$ \\
\hline \multirow[t]{2}{*}{$E M P(-1)$} & $0.102^{*}$ & 0.030 & $0.222^{*}$ & $0.774^{* * *}$ & $0.832^{* * *}$ & $0.912^{* * *}$ & $-0.175^{* * *}$ & $-0.158^{* * *}$ & $-0.099^{* * *}$ \\
\hline & $(0.060)$ & $(0.029)$ & $(0.126)$ & $(0.055)$ & $(0.030)$ & $(0.029)$ & $(0.028)$ & $(0.026)$ & $(0.023)$ \\
\hline \multirow[t]{2}{*}{$\operatorname{INVEST~(-1)~}$} & -0.001 & -0.002 & 0.032 & $0.012^{* * *}$ & $0.017^{* * *}$ & $0.016^{* *}$ & $0.331^{* * *}$ & $0.340^{* * *}$ & $0.379^{* * *}$ \\
\hline & $(0.014)$ & $(0.009)$ & $(0.037)$ & $(0.004)$ & $(0.004)$ & $(0.008)$ & $(0.015)$ & $(0.016)$ & $(0.020)$ \\
\hline \multirow[t]{2}{*}{$H E A(-1)$} & $0.047^{* * *}$ & $0.061^{* * *}$ & $0.065^{* * *}$ & $0.016^{* * *}$ & $0.009^{* * *}$ & $-0.005^{* *}$ & $0.103^{* * *}$ & $0.080^{* * *}$ & $0.045^{* * *}$ \\
\hline & $(0.008)$ & $(0.004)$ & $(0.008)$ & $(0.002)$ & $(0.001)$ & $(0.002)$ & $(0.005)$ & $(0.004)$ & $(0.003)$ \\
\hline \multirow[t]{2}{*}{$\operatorname{LOAN}(-1)$} & $0.216^{* * *}$ & $0.264^{* * *}$ & $0.215^{* * *}$ & $0.027^{*}$ & $0.032^{* * *}$ & $0.022^{* *}$ & $0.785^{* * *}$ & $0.609^{* * *}$ & $0.399^{* * *}$ \\
\hline & $(0.069)$ & $(0.035)$ & $(0.075)$ & $(0.015)$ & $(0.009)$ & $(0.011)$ & $(0.041)$ & $(0.030)$ & $(0.028)$ \\
\hline \multirow[t]{2}{*}{$\operatorname{SPEN}(-1)$} & $0.213^{* *}$ & $0.388^{* * *}$ & $0.520^{* * * *}$ & 0.046 & $0.064^{* * *}$ & 0.020 & $0.710^{* * *}$ & $0.579^{* * *}$ & $0.448^{* * *}$ \\
\hline & $(0.106)$ & $(0.050)$ & $(0.122)$ & $(0.031)$ & $(0.019)$ & $(0.025)$ & $(0.062)$ & $(0.048)$ & $(0.044)$ \\
\hline \multirow[t]{2}{*}{$T R A D E(-1)$} & -0.830 & -0.076 & $1.063^{*}$ & $0.888^{* * *}$ & $0.862^{* * *}$ & $0.411^{* * *}$ & $0.812^{* *}$ & $0.472^{*}$ & -0.0003 \\
\hline & $(0.591)$ & $(0.269)$ & $(0.576)$ & $(0.183)$ & $(0.132)$ & $(0.156)$ & $(0.332)$ & $(0.250)$ & $(0.229)$ \\
\hline \multirow[t]{2}{*}{$\operatorname{STOCK}(-1)$} & $-0.149^{*}$ & $0.119^{* *}$ & $0.295^{* * *}$ & 0.032 & $0.042^{* *}$ & 0.038 & 0.060 & 0.045 & 0.010 \\
\hline & $(0.085)$ & $(0.048)$ & $(0.091)$ & $(0.028)$ & $(0.019)$ & $(0.024)$ & $(0.062)$ & $(0.045)$ & $(0.043)$ \\
\hline Observation & 11064 & 14712 & 11064 & 11064 & 14712 & 11064 & 11064 & 14712 & 11064 \\
\hline$N$ & 461 & 613 & 461 & 461 & 613 & 461 & 461 & 613 & 461 \\
\hline
\end{tabular}


Regarding the interaction with firm-level output, employment and investment, Table 2.8 shows that these three firm indicators have the significant interaction, that is, firm employment and investment positively affect output and the increased output reversely promotes employment and investment growth. However, compared with the state-owned firms and private firms, I observe that the positive interaction of these three firm-level indicators is significantly larger for private firms. Specifically, firm employment has a larger effect on output for private firms than state-owned firms and firm investment has a significant effect on output only in private firms. This means that private firms have significant and higher investment efficiency in China (e.g., see Liu et al., 2018).

The corresponding results are given in Table 2.8 where all of my variables have their positive effects on firm-level output, employment and investment. The influences of these variables are greatly different on the state-owned and private firms. Banking health ratio and credit supply have larger impacts on the output for private firms but have smaller impacts on the investment for state-owned firms. However, the effects of banking health ratio and credit supply on output of state-owned firms are smaller but their effects on investment of state-owned firms are large. It demonstrates that the credit constraints widely exist for private firms, which can not get enough finance for investment. On the other hand, it also shows that the investment efficiency for state-owned firms is low. Meanwhile, the results demonstrate that government expenditure also promotes more growth of output and employment for private firms but its impact on investment of private firms is less than 
state-owned firms. Furthermore, net export has significant larger effects on the employment and investment of state-owned firms. US financial market performance has significant negative impacts on investment of state-owned firms.

The results are in line with studies such as by Faccio et al. (2006), Poncet et al. (2010) and Chan et al. (2012). Their studies observe that private firms face the highest degree of financial constraints, whereas state-owned enterprises do not experience any financial constraints. Meanwhile, politically-connected firms are more likely to be bailed out when they face financial difficulties compared to similar but non-politically connected firms (Cull and Xu, 2003; Firth et al., 2009; Chen et al., 2013; Liu et al., 2018). Jefferson (2016) also explains that the private firms are more profitable and efficient compared to state-owned firms in China because the state-own firms have the problems in corrupt practices, weak supervision and undefined property rights.

In order to stimulate the economy and adjust industry structure, the Chinese government promulgated the "top ten industry revitalization plan" in the early 2009 . The industries mainly cover manufacturing industries (automobile, equipment, shipbuilding manufacturing industry, non-ferrous metal industry, steel industry, textile industry, petrochemical industry), electronic information industries and logistics industries. The detailed measures include providing credit support, increasing tax rebates and government purchase on the products of the firms, such as agricultural products, refined oil and non-ferrous metal. 
Table 2.8 Results on firm-level variables: Ownership

\begin{tabular}{|c|c|c|c|c|c|c|}
\hline & \multicolumn{2}{|c|}{ Output } & \multicolumn{2}{|c|}{ Employment } & \multicolumn{2}{|c|}{ Investment } \\
\hline & State & Private & State & Private & State & Private \\
\hline \multirow[t]{2}{*}{ OUTPUT(-1) } & $0.123^{* * * *}$ & $0.185^{* * * *}$ & 0.005 & $0.025^{* * * *}$ & $0.036^{* * *}$ & $0.010^{* * * *}$ \\
\hline & $(0.046)$ & $(0.068)$ & $(0.006)$ & $(0.007)$ & $(0.009)$ & $(0.003)$ \\
\hline \multirow[t]{2}{*}{$E M P(-1)$} & $0.064^{*}$ & $0.174^{*}$ & $0.810^{* * * *}$ & $0.850^{* * * *}$ & $-0.153^{* * *}$ & $-0.111^{* * *}$ \\
\hline & $(0.038)$ & $(0.092)$ & $(0.043)$ & $(0.030)$ & $(0.024)$ & $(0.020)$ \\
\hline \multirow[t]{2}{*}{$\operatorname{INVEST}(-1)$} & 0.001 & $0.061^{*}$ & $0.016^{* * *}$ & $0.030^{* * *}$ & $0.348^{* * * *}$ & $0.489^{* * * *}$ \\
\hline & $(0.010)$ & $(0.034)$ & $(0.004)$ & $(0.007)$ & $(0.013)$ & $(0.016)$ \\
\hline \multirow[t]{2}{*}{$H E A(-1)$} & $0.046^{* * *}$ & $0.052^{* * * *}$ & $0.006^{* * *}$ & $0.006^{* * * *}$ & $0.058^{* * *}$ & $0.039^{* * *}$ \\
\hline & $(0.005)$ & $(0.006)$ & $(0.001)$ & $(0.002)$ & $(0.003)$ & $(0.003)$ \\
\hline \multirow[t]{2}{*}{$\operatorname{LOAN}(-1)$} & $0.072^{* * * *}$ & $0.166^{* * * *}$ & $0.016^{* * *}$ & $0.017^{* * * *}$ & $0.380^{* * *}$ & $0.256^{* * *}$ \\
\hline & $(0.024)$ & $(0.037)$ & $(0.005)$ & $(0.006)$ & $(0.012)$ & $(0.011)$ \\
\hline \multirow[t]{2}{*}{ SPEN(-1) } & $0.267^{* * * *}$ & $0.422^{* * * *}$ & 0.020 & $0.070^{* * * *}$ & $0.525^{* * *}$ & $0.394^{* * *}$ \\
\hline & $(0.056)$ & $(0.113)$ & $(0.018)$ & $(0.027)$ & $(0.044)$ & $(0.041)$ \\
\hline \multirow[t]{2}{*}{$T R A D E(-1)$} & 0.200 & 1.621 & $0.965^{* * *}$ & $0.538^{* * * *}$ & $2.605^{* * * *}$ & $2.047^{* * *}$ \\
\hline & $(0.345)$ & $(0.651)$ & $(0.129)$ & $(0.178)$ & $(0.265)$ & $(0.246)$ \\
\hline \multirow[t]{2}{*}{$\operatorname{STOCK}(-1)$} & 0.083 & 0.040 & $0.045^{* * *}$ & 0.003 & $-0.168^{* * *}$ & $-0.101^{* * *}$ \\
\hline & $(0.051)$ & $(0.086)$ & $(0.016)$ & $(0.025)$ & $(0.043)$ & $(0.038)$ \\
\hline Observation & 19728 & 13104 & 19728 & 13104 & 19728 & 13104 \\
\hline$N$ & 822 & 546 & 822 & 546 & 822 & 546 \\
\hline
\end{tabular}

Note: ${ }^{* * *},{ }^{* * *}$ and ${ }^{*}$ show the significance at the level of $1 \%, 5 \%$ and $10 \%$, respectively. The standard error is estimated by white robust covariance. The model is estimated in first differences with third lagged instruments. The sample covers all the 13 industries and the sample period is from 2008 to 2014 . All the variables are removed by trend and seasonality. I do not report the influences of second and third lagged output, employment and investment because of the space limitations.

Since industries are supported differently due to government policies, I replicate my investigation based on the 13 industries given in Table 2.2. I find that some industries have the strong interaction with firm-level output, employment and investment. To be specific, firm investment or employment positively affect output, including Agriculture and Relevant Industry (ARI), Manufacturing Industry (MAN), Utility Industry (UTI) and Real Estate Industry (EST). On the other hand, the increased output reversely promotes the growth of employment or investment, including Manufacturing Industry (MAN), Financial 
\& Insurance Industry (FIN), Real Estate Industry (EST), Social Service Industry (SOC) and Communication \& Culture Industry (COM). It means that the different industries have large heterogeneity in the interaction of three firm-level indicators.

Regarding the effects of the banking health ratio and credit supply on firm-level output, employment and investment, I find that banking health ratio and credit supply have significant and positive impacts on the output in almost all the industries, expect Mining Industry (MIN), Information Technology Industry (INF) and Financial \& Insurance Industry (FIN). Manufacturing Industry (MAN), Construction Industry (CON), Transportation \& Warehousing Industry (TRA) and Real Estate Industry (EST) are larger positively affected by banking health ratio and credit supply. Banking health ratio and credit supply also have significant positive impacts on the employment of Manufacturing Industry (MAN) because Manufacturing Industry (MAN) has a large demand for labor with the increase of investment and output. In the case of investment, I observe that banking health ratio and credit supply have significant positive impacts on all the industries, where Manufacturing Industry (MAN), Utility Industry (UTI), Mining Industry (MIN), Construction Industry (CON) and Transportation \& Warehousing Industry (TRA) receive larger financial support.

Furthermore, I observe that the fiscal policy has larger significant impacts on the output of the industries, including Agriculture and Relevant Industry (ARI), Manufacturing Industry (MAN) and Real Estate Industry (EST). The larger impacts on the 
employment lie in the Manufacturing Industry (MAN) and Social Service Industry (SOC). The larger impacts on the investment lie in the Manufacturing Industry (MAN), Agriculture and Relevant Industry (ARI), Utility Industry (UTI), Mining Industry (MIN), Construction Industry (CON) and Transportation \& Warehousing Industry (TRA).

Regarding the external economic shocks, net export has significant effects on the output in the Real Estate Industry (EST) and Communication \& Culture Industry (COM). Net export has significant effects on the employment of Construction Industry (CON), Social Service Industry (SOC) and Communication \& Culture Industry (COM). In the investment aspect, net export has significant effects on the investment of most industries, except for Transportation \& Warehousing Industry (TRA) and Conglomerate Industry (CONG). The US financial market performance does not have significant influences on the output, employment and investment for these industries.

In summary, among these industries, it is evident that the industries in need of financial support in the revitalization plan really obtain banking credit and government fiscal support, including Manufacturing Industry (MAN), Utility Industry (UTI) and Transportation \& Warehousing Industry (TRA). However, besides these industries, some other problematic industries due to their potential impacts on boosting housing prices, especially Mining Industry (MIN), Construction Industry (CON) and Real Estate Industry (EST), have also received banking credit. Furthermore, some industries are exposed to 
large external economic impacts, such as Agriculture and Relevant Industry (ARI) and Utility Industry (UTI).

Since the positive roles of financial and fiscal policies might be different in the Great Recession (2008-2009) and recovery period (2010-2014) (e.g., see Campello et al, 2010, Lin et al, 2011, Corsetti et al., 2012; Ouyang and Peng, 2015), I investigate the effects of banking health ratio, credit supply and government expenditure considering the interaction with the Great Recession dummy. The regression models are shown as:

$$
\begin{aligned}
& \text { OUTPUT }_{i t}=\sum_{j-1}^{k} \alpha_{j}^{o, 1} \text { OUTPUT } T_{i t-j}+\sum_{j-1}^{k} \alpha_{j}^{o, 2} E M P_{i t-j}+\sum_{j-1}^{k} \alpha_{j}^{o, 3} \text { INVEST }_{i t-j}+b_{1}^{o} \text { HEA }_{t-1}+b_{2}^{o} \text { LOAN }_{t-1} \\
& +b_{3}^{o} \operatorname{SPEN}_{t-1}+b_{4}^{o} \operatorname{TRADE}_{t-1}+b_{5}^{o} \text { STOCK }_{t-1}+b_{6}^{o} G_{t} \times H E A_{t-1}+b_{7}^{o} G_{t} \times L O A N_{t-1}+b_{8}^{o} G_{t} \times S P E N_{t-1} \\
& +\alpha_{i}^{o}+\varepsilon_{i t}^{o} \\
& E M P_{i t}=\sum_{j-1}^{k} \alpha_{j}^{e, 1} \text { OUTPUT }_{i t-j}+\sum_{j-1}^{k} \alpha_{j}^{e, 2} \operatorname{EMP}_{i t-j}+\sum_{j-1}^{k} \alpha_{j}^{e, 3} \operatorname{INVEST}_{i t-j}+b_{1}^{e} \text { HEA }_{t-1}+b_{2}^{e} \text { LOAN }_{t-1} \\
& +b_{3}^{e} \operatorname{SPEN}_{t-1}+b_{4}^{e} \operatorname{TRADE}_{t-1}+b_{5}^{e} \operatorname{STOCK}_{t-1}+b_{6}^{e} G_{t} \times H E A_{t-1}+b_{7}^{e} G_{t} \times L O A N_{t-1}+b_{8}^{e} G_{t} \times S P E N_{t-1} \\
& +\alpha_{i}^{e}+\varepsilon_{i t}^{e} \\
& \operatorname{INVEST}_{i t}=\sum_{j-1}^{k} \alpha_{j}^{i, 1} \text { OUTPUT }_{i t-j}+\sum_{j-1}^{k} \alpha_{j}^{i, 2} \operatorname{EMP}_{i t-j}+\sum_{j-1}^{k} \alpha_{j}^{i, 3} \operatorname{INVEST}_{i t-j}+b_{1}^{i} \text { HEA }_{t-1}+b_{2}^{i} \text { LOAN }_{t-1} \\
& +b_{3}^{i} \operatorname{SPEN}_{t-1}+b_{4}^{i} \operatorname{TRADE}_{t-1}+b_{5}^{i} \operatorname{STOCK}_{t-1}+b_{6}^{i} G_{t} \times H E A_{t-1}+b_{7}^{i} G_{t} \times \operatorname{LOAN}_{t-1}+b_{8}^{i} G_{t} \times \operatorname{SPEN}_{t-1} \\
& +\alpha_{i}^{i}+\varepsilon_{i t}^{i}
\end{aligned}
$$

where $G_{t}$ is the dummy variable $(G=1)$ for the Great Recession. It covers the fourth quarter in 2008 to the fourth quarter in 2009 since the GDP growth in this period declines sharply from $11 \%$ to $8 \%$.

Table 2.9 shows that firm-level output, employment and investment have the expected significant interaction, that is, firm employment and investment positively affect output 
and the increased output reversely promotes growth of employment and investment growth. Besides, banking health ratio and credit supply have their expected positive impacts on the firm-level output, employment and investment. Besides, government expenditure and net export also have positive and significant effects on output, employment and investment. The US financial market performance has a positive impact on output and employment but its impact on investment is negative. Most results are very similar as the pervious findings.

Regarding the interaction effects of banking health ratio, credit supply and government expenditure with Great Recession dummy, I observe that the interaction effect of banking health ratio with the Great Recession dummy is -0.073 , suggesting that the influence of banking health ratio on the output is about $0.034(0.107$ minus 0.073$)$. Furthermore, the interaction influence of banking health ratio on the employment and investment are 0.005 (0.011 plus 0.006$)$ and 0.29 (0.146 minus 0.117$)$, respectively. The results mean that the Great Recession hurts the positive effects of banking health ratio, which reflects the importance of quality of credit intermediation in the economic recession (see Bernanke, 1983).

Regarding the interaction effect of credit supply and Great Recession dummy, I find the interaction effect is significant positive. To be specific, the influence of credit supply on the output is $0.236(0.054$ plus 0.182$)$ in the Great Recession. The effects on the employment and investment are 0.050 (0.009 plus 0.041$)$ and 0.547 (0.266 plus 0.281$)$, 
respectively. I also find that the interacting influences of government expenditure are very significant. The influences on the firm-level output, employment and investment are 0.899 (0.324 plus 0.575$), 0.040$ ( 0.040 plus 0$)$ and 0.016 (0.495 minus 0.479$)$, respectively. The results are consistent with the findings of some papers. For example, Corsetti et al. (2012) find that output multipliers of government expenditure are especially larger in times of financial crisis. Ouyang and Peng (2015) document the effect of 2008 economic stimulus plan temporarily affects only in the Great Recession period (around 2 years).

Therefore, I acknowledge that credit supply and government expenditure have more of an impact in the Great Recession, which supports the success of the Chinese government's "RMB 4-trillion stimulus plan" and the RMB 14.6 trillion growth of bank credit. However, the positive influences of banking health ratio diminish quickly after the Great Recession because of possible bad loan increase and credit oversupply.

\subsubsection{Dynamic analysis}

In order to expound on the dynamic nature of my empirical model, this section presents the impulse response functions and the variance decompositions from the panel VAR model. In particular, I investigate the dynamic effects of the interaction of firm-level variables and the shocks of banking health ratio, credit supply, government expenditure and external economic factors on firm-level variables. I explore their impulse reaction functions and variance decompositions individually. 
Table 2.9 Results on the regression models with interaction effects

\begin{tabular}{|c|c|c|c|c|c|c|c|c|c|}
\hline & \multicolumn{3}{|c|}{ Output } & \multicolumn{3}{|c|}{ Employment } & \multicolumn{3}{|c|}{ Investment } \\
\hline & (1) & (2) & (3) & $(1)$ & (2) & (3) & $(1)$ & (2) & (3) \\
\hline OUTPUT(-1) & $\begin{array}{c}0.177^{* * * *} \\
(0.044)\end{array}$ & $\begin{array}{l}0.178^{* * * *} \\
(0.044)\end{array}$ & $\begin{array}{l}0.178^{* * * *} \\
(0.044)\end{array}$ & $\begin{array}{l}0.016^{* * *} \\
(0.005)\end{array}$ & $\begin{array}{l}0.016^{* * * *} \\
(0.005)\end{array}$ & $\begin{array}{l}0.016^{* * * *} \\
(0.005)\end{array}$ & $\begin{array}{l}0.019^{* * *} \\
(0.003)\end{array}$ & $\begin{array}{c}0.020^{* * * *} \\
(0.003)\end{array}$ & $\begin{array}{l}0.021^{* * * *} \\
(0.003)\end{array}$ \\
\hline$E M P(-1)$ & $\begin{array}{l}0.119^{* * * *} \\
(0.044)\end{array}$ & $\begin{array}{l}0.118^{* * *} \\
(0.044)\end{array}$ & $\begin{array}{c}0.119^{* * * *} \\
(0.044)\end{array}$ & $\begin{array}{l}0.835^{* * *} \\
(0.025)\end{array}$ & $\begin{array}{l}0.834^{* * * *} \\
(0.025)\end{array}$ & $\begin{array}{l}0.835^{* * * *} \\
(0.025)\end{array}$ & $\begin{array}{c}-0.134^{* * * *} \\
(0.015)\end{array}$ & $\begin{array}{c}-0.135^{* * *} \\
(0.015)\end{array}$ & $\begin{array}{c}-0.131^{* * *} \\
(0.015)\end{array}$ \\
\hline $\operatorname{INVEST}(-1)$ & $\begin{array}{c}0.014 \\
(0.011)\end{array}$ & $\begin{array}{c}0.015 \\
(0.011)\end{array}$ & $\begin{array}{l}0.018^{*} \\
(0.011)\end{array}$ & $\begin{array}{l}0.018^{* * *} \\
(0.003)\end{array}$ & $\begin{array}{c}0.018^{* * * *} \\
(0.003)\end{array}$ & $\begin{array}{c}0.018^{* * * *} \\
(0.003)\end{array}$ & $\begin{array}{c}0.381^{* * * *} \\
(0.010)\end{array}$ & $\begin{array}{c}0.382^{* * * *} \\
(0.010)\end{array}$ & $\begin{array}{c}0.384^{* * *} \\
(0.010)\end{array}$ \\
\hline$H E A(-1)$ & $\begin{array}{l}0.107^{* * * *} \\
(0.010)\end{array}$ & $\begin{array}{l}0.054^{* * *} \\
(0.004)\end{array}$ & $\begin{array}{l}0.051^{* * * *} \\
(0.004)\end{array}$ & $\begin{array}{l}0.011^{* * * *} \\
(0.003)\end{array}$ & $\begin{array}{l}0.007^{* * * *} \\
(0.001)\end{array}$ & $\begin{array}{l}0.006^{* * * *} \\
(0.001)\end{array}$ & $\begin{array}{l}0.146^{* * *} \\
(0.006)\end{array}$ & $\begin{array}{l}0.061^{* * * *} \\
(0.002)\end{array}$ & $\begin{array}{l}0.049^{* * * *} \\
(0.002)\end{array}$ \\
\hline $\operatorname{LOAN}(-1)$ & $\begin{array}{l}0.086^{* * * *} \\
(0.021)\end{array}$ & $\begin{array}{l}0.070^{* * * *} \\
(0.022)\end{array}$ & $\begin{array}{l}0.091^{* * * *} \\
(0.022)\end{array}$ & $\begin{array}{l}0.015^{* * *} \\
(0.004)\end{array}$ & $\begin{array}{l}0.009^{* *} \\
(0.004)\end{array}$ & $\begin{array}{l}0.016^{* * * * *} \\
(0.004)\end{array}$ & $\begin{array}{l}0.289^{* * * *} \\
(0.009)\end{array}$ & $\begin{array}{l}0.266^{* * * *} \\
(0.009)\end{array}$ & $\begin{array}{l}0.335^{* * * *} \\
(0.009)\end{array}$ \\
\hline $\operatorname{SPEN}(-1)$ & $\begin{array}{l}0.441^{* * * *} \\
(0.055)\end{array}$ & $\begin{array}{l}0.335^{* * *} \\
(0.053)\end{array}$ & $\begin{array}{l}0.324^{* * * *} \\
(0.054)\end{array}$ & $\begin{array}{l}0.049^{* * * *} \\
(0.016)\end{array}$ & $\begin{array}{l}0.036^{* * * *} \\
(0.014)\end{array}$ & $\begin{array}{l}0.040^{* * * *} \\
(0.014)\end{array}$ & $\begin{array}{l}0.607^{* * * *} \\
(0.030)\end{array}$ & $\begin{array}{l}0.437^{* * * *} \\
(0.029)\end{array}$ & $\begin{array}{l}0.495^{* * * *} \\
(0.030)\end{array}$ \\
\hline$T R A D E(-1)$ & $\begin{array}{l}1.057^{* * * *} \\
(0.319)\end{array}$ & $\begin{array}{l}0.968^{* * * *} \\
(0.317)\end{array}$ & $\begin{array}{l}0.605^{*} \\
(0.317)\end{array}$ & $\begin{array}{l}0.864^{* * * *} \\
(0.101)\end{array}$ & $\begin{array}{l}0.902^{* * * * *} \\
(0.102)\end{array}$ & $\begin{array}{l}0.825^{* * * *} \\
(0.101)\end{array}$ & $\begin{array}{l}3.092^{* * * *} \\
(0.179)\end{array}$ & $\begin{array}{l}2.927^{* * * *} \\
(0.175)\end{array}$ & $\begin{array}{l}2.444^{* * * *} \\
(0.180)\end{array}$ \\
\hline $\operatorname{STOCK}(-1)$ & $\begin{array}{l}0.159^{* * * *} \\
(0.048)\end{array}$ & $\begin{array}{l}-0.066 \\
(0.044)\end{array}$ & $\begin{array}{l}0.129^{* * *} \\
(0.056)\end{array}$ & $\begin{array}{l}0.041^{* * * *} \\
(0.014)\end{array}$ & $\begin{array}{c}0.007 \\
(0.014)\end{array}$ & $\begin{array}{l}0.034^{* * *} \\
(0.016)\end{array}$ & $\begin{array}{l}0.076^{* * * *} \\
(0.029)\end{array}$ & $\begin{array}{c}-0.279^{* * * *} \\
(0.029)\end{array}$ & $\begin{array}{c}-0.213^{* * * *} \\
(0.039)\end{array}$ \\
\hline$H E A(-1) \times C R I S I S(-1)$ & $\begin{array}{c}-0.073^{* * *} \\
(0.011)\end{array}$ & & & $\begin{array}{l}-0.006^{* *} \\
(0.003)\end{array}$ & & & $\begin{array}{c}-0.117^{* * * *} \\
(0.006)\end{array}$ & & \\
\hline $\operatorname{LOAN}(-1) \times \operatorname{CRISIS}(-1)$ & & $\begin{array}{c}0.182^{* * * *} \\
(0.023)\end{array}$ & & & $\begin{array}{l}0.041^{* * * *} \\
(0.005)\end{array}$ & & & $\begin{array}{l}0.281^{* * * *} \\
(0.015)\end{array}$ & \\
\hline $\operatorname{SPEN}(-1)) \times \operatorname{CRISIS}(-1)$ & & & $\begin{array}{c}0.575^{* * *} \\
(0.185)\end{array}$ & & & $\begin{array}{c}0.026 \\
(0.037)\end{array}$ & & & $\begin{array}{c}-0.479^{* * * *} \\
(0.133)\end{array}$ \\
\hline Observation & 36840 & 36840 & 36840 & 36840 & 36840 & 36840 & 36840 & 36840 & 36840 \\
\hline$N$ & 1535 & 1535 & 1535 & 1535 & 1535 & 1535 & 1535 & 1535 & 1535 \\
\hline
\end{tabular}

Note: $^{* * * * *},{ }^{*}$ and ${ }^{*}$ show the significance at the level of $1 \%, 5 \%$ and $10 \%$, respectively. The standard error is estimated by white robust covariance. The model is estimated in first differences with third lagged instruments. The sample covers all the 13 industries and the sample period is from 2008 to 2014. 
Figure 2.3 shows that firm-level output, employment and investment positively respond to their lags. Furthermore, firm output responds positively to employment and investment. Firm employment responds positively to output but responds negatively to investment. Firm investment positively responds to output and employment. Among the results, I observe that the growth of firm output is $60 \%, 6 \%$ and $2.4 \%$ and diminishes after responding to the shocks of lagged output, employment and investment, respectively.

Furthermore, the results show that firm-level output, employment and investment respond positively to banking health ratio, credit supply and government expenditure. To be specific, I observe that firm-level output, employment and investment increase $3.1 \%$, $0.6 \%$ and $1.0 \%$ in the highest point around the $3^{\text {rd }}$ period in the one unit standard deviation shock of banking health ratio. The output and investment converge to 0 around the $5^{\text {th }}$ period. In the one unit standard deviation shock from credit supply, firm output and investment increase $4 \%$ and $90 \%$ in the highest point around the $3^{\text {rd }}$ period and converge to 0 in the $5^{\text {th }}$ period, respectively. However, employment only increases $0.5 \%$ and converges to 0 around the $10^{\text {th }}$ period. Besides, in the one unit standard deviation shock of government expenditure, output and investment increase $1.5 \%$ and $28 \%$ in the highest point around the $3^{\text {rd }}$ period but the response of employment is very small.

In summary, these results show that the shocks of banking indicators and government expenditure have a large effect on output and investment but their effects are significant in a very short period because Chinese government takes "RMB 4-trillion stimulus plan" 
only in 2008 and 2009 and prevents too fast credit growth after 2009 (see Ouyang and Peng, 2015). Besides, I observe that the effects of bank credit and government expenditure on investment are much larger than output and employment.

Furthermore, I observe that the responses of firm-level output, employment and investment to net export and US financial market performance are not very large. Specifically, in the one unit standard deviation shock of net export, firm-level output, employment and investment increase $1.5 \%, 1.5 \%$ and $6 \%$, respectively. However, output and employment do not have significant responses for the one unit standard deviation shock of US financial market performance but the investment decreases $2.1 \%$.

Figure 2.3 Results of the impulse response functions

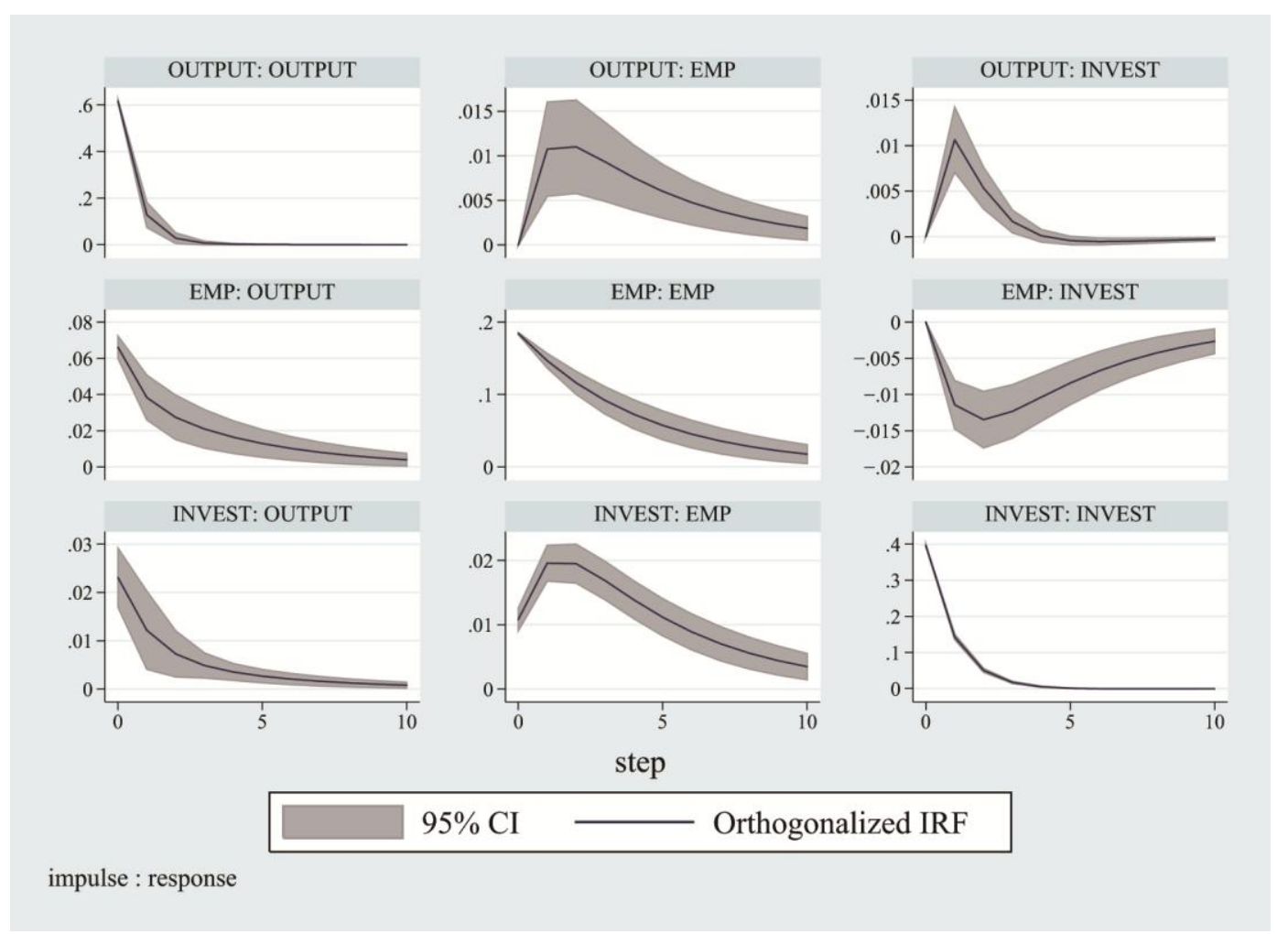




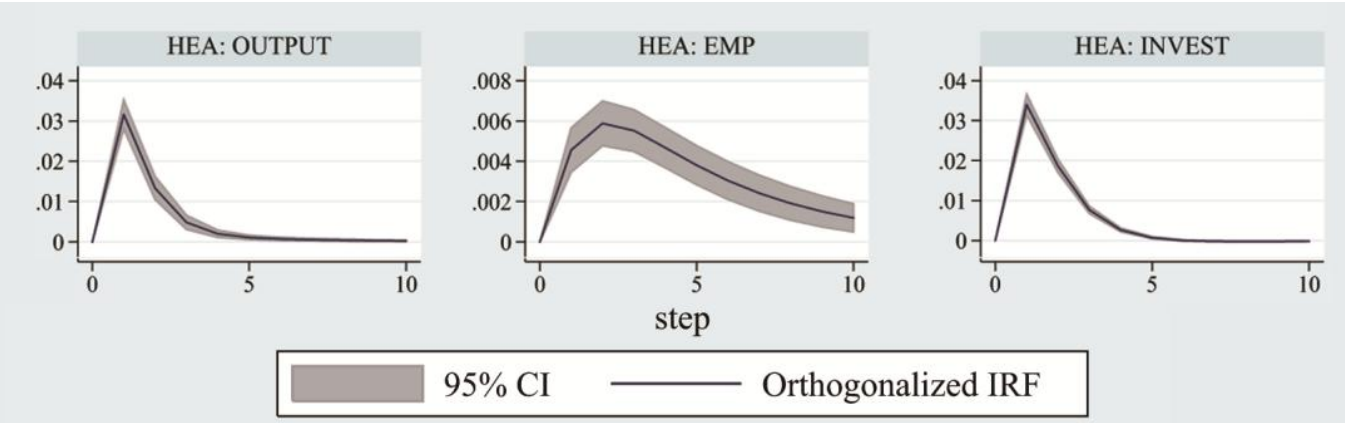

impulse : response
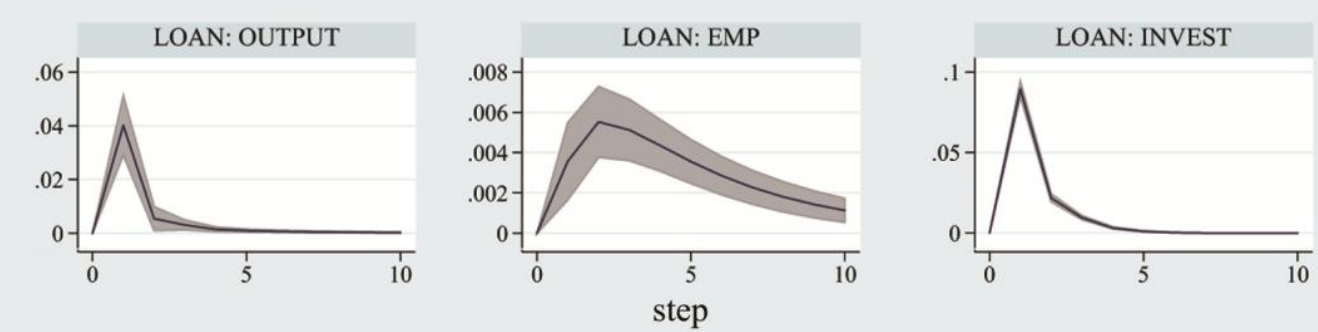

\section{5\% CI Orthogonalized IRF}

impulse : response
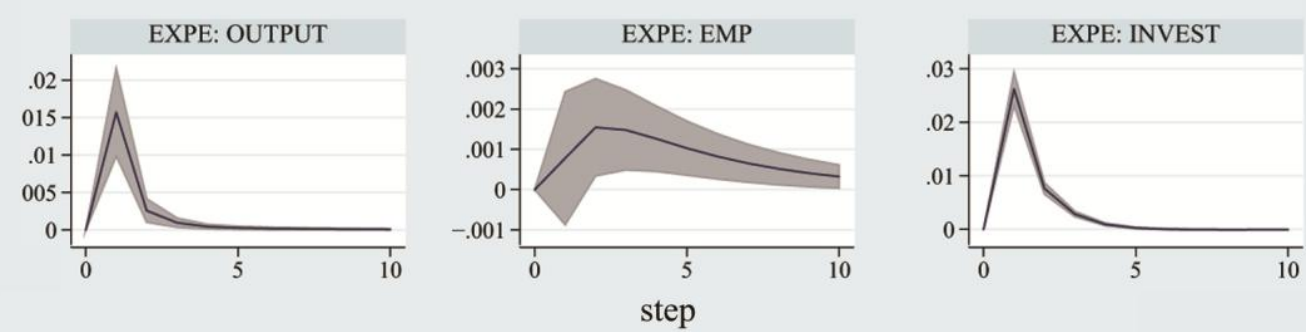

$95 \%$ CI - Orthogonalized IRF

impulse : response
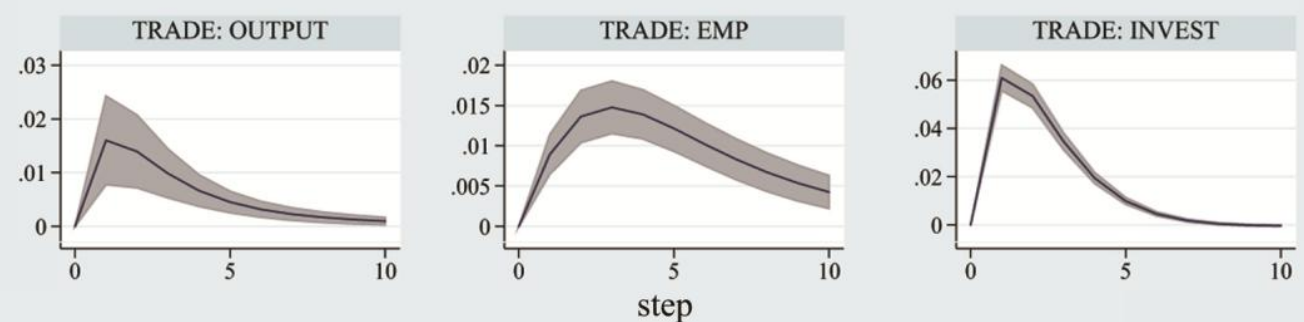

$95 \% \mathrm{CI}$

Orthogonalized IRF

impulse : response 


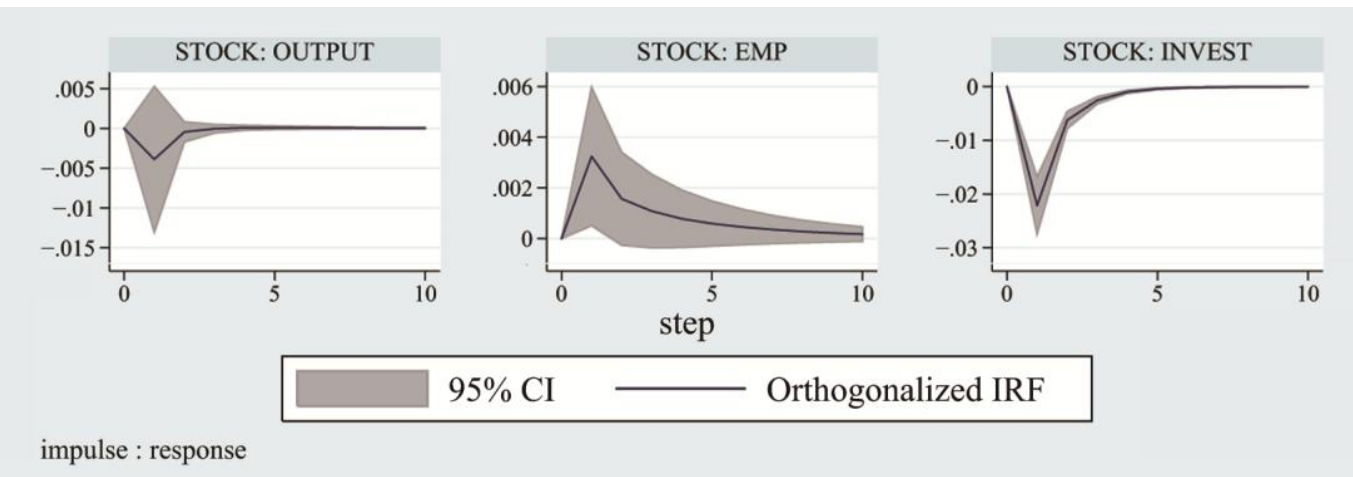

Note: I examine the interaction of firm output, employment and investment. Since I think the shocks of banking health ratio, credit supply, government expenditure, net trade and US financial market performance may have some correlations with each other, I examine their impulse reaction function one by one. The number of Monte Carlo is 1000.

Furthermore, I apply variance decompositions to assess the importance of changes in one variable to explain the changes in other variable. As I investigate the interaction of three firm-level indicators and the shocks from banking health ratio, credit supply, government expenditure, net trade and US financial market performance one by one, Table 2.10 shows that the changes of firm-level output are affected by the lagged output (90.66\%), employment (7.78\%) and investment (1.56\%) and affected by the shock of government expenditure $(4.26 \%)$ and credit supply $(3.13 \%)$ in the $10^{\text {th }}$ period forecast horizon, respectively. For the responses of firm-level employment, the large influential variables refer to the lagged employment (95.58\%), output (4.31\%) and government expenditure $(3.51 \%)$ in the $10^{\text {th }}$ period forecast horizon. The impact of other financial variables is small. For the responses of firm-level investment, I find that the lagged investment $(96.00 \%)$, banking health ratio (14.94\%), credit supply $(8.21 \%)$ and government expenditure (6.99\%) have large effects in the $10^{\text {th }}$ period forecast horizon. 
In summary, I confirm that banking health ratio, credit supply and government expenditure have large and significant explanations for the change of firm output, employment and investment while credit supply and government expenditure are much more effective on firm investment than output and employment. However, Chinese government's financial and fiscal policies cannot explain a lot since these polices are carried on only in 2008 and 2009. The US financial market performance also has a very little influence since this impact is indirect on the firm output, employment and investment.

Since state-owned firms and private firms have a large difference in size, liability ratio and profitability, I divide the whole sample by ownership and apply impulse reaction functions and variance decompositions to investigate these two types of firms. Regarding the interaction with firm output, employment and investment, I observe that they have expected influences on each other in both types of firms. Compared with state-owned firms and private firms, I observe that the output of private firms have a larger response to employment but has a smaller response for investment. The state-owned firms have a larger response to investment but have a smaller response for employment. 
Table 2.10 Results on the variance decompositions

\begin{tabular}{|c|c|c|c|c|c|c|c|c|c|}
\hline \multirow[t]{3}{*}{$\begin{array}{c}\text { Response } \\
\text { variable }\end{array}$} & \multirow{3}{*}{$\begin{array}{c}\text { Forecast } \\
\text { horizon }\end{array}$} & \multicolumn{8}{|c|}{ Impulse variable } \\
\hline & & & (1) & & (2) & (3) & (4) & (5) & (6) \\
\hline & & OUTPUT & EMP & INVEST & HEA & LOAN & EXPE & TRADE & STOCK \\
\hline \multirow{6}{*}{ OUTPUT } & 0 & $0.00 \%$ & $0.00 \%$ & $0.00 \%$ & $0.00 \%$ & $0.00 \%$ & $0.00 \%$ & $0.00 \%$ & $0.00 \%$ \\
\hline & 2 & $99.35 \%$ & $0.16 \%$ & $0.49 \%$ & $0.39 \%$ & $0.38 \%$ & $0.01 \%$ & $0.05 \%$ & $0.03 \%$ \\
\hline & 4 & $97.96 \%$ & $1.00 \%$ & $1.04 \%$ & $0.58 \%$ & $2.12 \%$ & $1.83 \%$ & $0.11 \%$ & $0.04 \%$ \\
\hline & 6 & $95.98 \%$ & $2.64 \%$ & $1.39 \%$ & $0.52 \%$ & $2.86 \%$ & $3.14 \%$ & $0.12 \%$ & $0.07 \%$ \\
\hline & 8 & $93.52 \%$ & $4.95 \%$ & $1.52 \%$ & $0.51 \%$ & $3.05 \%$ & $3.92 \%$ & $0.13 \%$ & $0.10 \%$ \\
\hline & 10 & $90.66 \%$ & $7.78 \%$ & $1.56 \%$ & $0.51 \%$ & $3.13 \%$ & $4.26 \%$ & $0.13 \%$ & $0.12 \%$ \\
\hline \multirow{6}{*}{ EMP } & 0 & $0.00 \%$ & $0.00 \%$ & $0.00 \%$ & $0.00 \%$ & $0.00 \%$ & $0.00 \%$ & $0.00 \%$ & $0.00 \%$ \\
\hline & 2 & $0.83 \%$ & $99.17 \%$ & $0.00 \%$ & $0.00 \%$ & $0.01 \%$ & $0.12 \%$ & $0.01 \%$ & $0.26 \%$ \\
\hline & 4 & $1.90 \%$ & $98.00 \%$ & $0.10 \%$ & $0.08 \%$ & $0.10 \%$ & $1.45 \%$ & $0.01 \%$ & $0.29 \%$ \\
\hline & 6 & $2.81 \%$ & $97.09 \%$ & $0.10 \%$ & $0.10 \%$ & $0.07 \%$ & $2.78 \%$ & $0.01 \%$ & $0.41 \%$ \\
\hline & 8 & $3.61 \%$ & $96.28 \%$ & $0.10 \%$ & $0.14 \%$ & $0.05 \%$ & $3.31 \%$ & $0.01 \%$ & $0.43 \%$ \\
\hline & 10 & $4.31 \%$ & $95.58 \%$ & $0.11 \%$ & $0.16 \%$ & $0.04 \%$ & $3.51 \%$ & $0.01 \%$ & $0.44 \%$ \\
\hline \multirow{6}{*}{ INVEST } & 0 & $0.00 \%$ & $0.00 \%$ & $0.00 \%$ & $0.00 \%$ & $0.00 \%$ & $0.00 \%$ & $0.00 \%$ & $0.00 \%$ \\
\hline & 2 & $1.19 \%$ & $0.12 \%$ & $98.69 \%$ & $7.08 \%$ & $2.85 \%$ & $0.13 \%$ & $0.31 \%$ & $0.04 \%$ \\
\hline & 4 & $2.13 \%$ & $0.20 \%$ & $97.68 \%$ & $14.13 \%$ & $8.16 \%$ & $6.47 \%$ & $0.83 \%$ & $0.23 \%$ \\
\hline & 6 & $2.79 \%$ & $0.28 \%$ & $96.92 \%$ & $14.62 \%$ & $8.20 \%$ & $7.29 \%$ & $0.91 \%$ & $0.28 \%$ \\
\hline & 8 & $3.18 \%$ & $0.41 \%$ & $96.41 \%$ & $15.08 \%$ & $8.20 \%$ & $7.07 \%$ & $0.97 \%$ & $0.28 \%$ \\
\hline & 10 & $3.41 \%$ & $0.59 \%$ & $96.00 \%$ & $14.94 \%$ & $8.21 \%$ & $6.99 \%$ & $0.97 \%$ & $0.29 \%$ \\
\hline
\end{tabular}

Note: I obtain the variance decomposition in six models by considering the interaction of firm output, employment and investment and the shock one by one, including banking health ratio, credit supply, government expenditure, net trade and US financial market performance. The number of Monte Carlo is 1000 . 
In the case of firm-level output, employment and investment response to banking health ratio, credit supply, government expenditure and external economic factors, I find that banking health ratio has the positive effects on the firm output and employment for both types of firms while it has much larger effects on the investment of state-owned firms. Credit supply has a larger and significant effect on the private firms in output and employment than state-owned firms but its role on investment is much larger for state-owned firms. Similarly, government expenditure has a significant larger effect on private firms in output and employment than state-owned firms but the investment of state-owned firms is more positively affected by government expenditure. Regarding the external economic factors, net export has larger effects on the investment of state-owned firms and the output of private firms. However, the output, employment and investment of both types of firms do not have significant responses for the shock of US financial market performance.

In summary, in the dynamic analysis perspective, I can conclude that the shocks of banking indicators and government expenditure for both the state-owned firms and private firms have a significant effect on output and investment but converge in a very short period, which represents the temporary effect of the Chinese government "RMB 4-trillion stimulus plan" and RMB 14.6 trillion of bank credit growth. Furthermore, the shocks of banking indicators and government expenditure for the investment of state-owned firms are much larger than private firms while the shocks for output and 
employment for state-owned firms are smaller than private firms, which are consistent to the static results in the Panel VAR model and confirm the financial constraints for private firms and low investment efficiency for state-owned firms.

Comparing the results of variance decompositions of state-owned firms with private firms, I find that the response of state-owned firms' output for employment (2.93\%) and investment $(0.13 \%)$ is smaller than private firms but state-owned firm output's response for bank credit (4.57\%) and government expenditure (15.57\%) is a little bit larger than private firms in the 10th period forecast horizon, respectively. The employment of state-owned firms is greatly affected by output (1.81\%) and government expenditure (5.18\%) but the employment of private firms is greatly affected by its output (9.74\%) and government expenditure (3.95\%). In the case of investment, the state-owned firms are more affected for output $(9.04 \%)$, banking health ratio (13.74\%), credit supply (11.80\%) and government expenditure $(32.37 \%)$ in the 10th period forecast horizon. The investment of private firms is affected by output (2.06\%), banking health ratio (9.91\%), credit supply (9.02\%) and government expenditure (5.96\%) in the 10th period forecast horizon. These results also show that private firms have larger financial constraints and the investment efficiency of state-owned firms is lower. 


\subsection{Conclusions}

I have investigated the roles played by the Chinese government on the recovery of Chinese firms through its financial policy of "RMB 14.6 trillion of bank credit growth" and the fiscal policy of the "RMB 4-trillion stimulus plan" from the Great Recession to 2014. My analysis explores the interaction of Chinese firm-level output, employment and investment and the effects of these policies on these three firm-level indicators. The results have presented that three firm-level indicators have strong interaction, that is, firm employment and investment positively affect output. The increased firm output reversely promotes the growth of employment and investment. I also observe that both credit supply and a healthy banking system contribute to the growth of firm-level output, employment and investment; fiscal policies through government expenditure have also been shown to be effective on the recovery based on the firm-level data. Among the three firm-level indicators, firm investment is stimulated greatly and grows extensively. Both of these results imply that the Chinese financial and fiscal policies have been successful for recovery in the Great Recession. The results also show that Chinese exports also have significant impacts on the Chinese economic recovery.

Since Chinese firms might face the financial constrains faced by different government policies due to their size, liability, profitability, ownership and industry, I also investigate how the effects of the banking indicators and the government expenditure change with such firm characteristics. The results suggest that credit supply and a healthy banking 
system are more effective on the investment of larger and state-owned firms, but the investment efficiency of larger and state-owned firms is lower than smaller and private firms. Indicators of banking credit, a healthy banking system and government expenditure are shown to be more impactful on the output and investment of high- and mediumliability firms. Furthermore, higher profitable firms receive more credit support compared to medium and low profitable firms. Finally, consistent with the "top ten industry revitalization plan" promulgated by the Chinese government in early 2009, certain industries have benefited more from financial and fiscal policies. By using impulse reaction functions and variance decompositions, I also observe that banking health ratio, credit supply, government expenditure and external economic factors have significant dynamic effects on the firm-level output, employment and investment but these variables are relevant only in the Great Recession (2008-2009).

Despite the success of these Chinese financial and fiscal policies in the Great Recession, there are corresponding costs of the soaring banking credit growth and higher government expenditure. In particular, Chinese commercial banks have a large quantity of loan facing insolvency risk if the firms cannot repay their loan, because certain industries have serious problems of having overcapacity, low production efficiency and limited development potential. Moreover, the Chinese government has a major financial burden due to the financing of its policies through government debt. Such macroeconomic issues deserve further research in the future. 


\section{CHAPTER 3}

\section{FINANCIAL SECTOR DEVELOPMENT AND GROWH VOLATILITY}

\subsection{Introduction}

Growth volatility is an important concern for a government, who wants to employ the policies to reduce exogenous shocks and smooth aggregate fluctuations without aggravating the business cycle. However, the studies to explore the trend of growth volatility and its relationship with financial sector development in the global perspective are limited. Some scholars investigate the roles of financial sector development on the growth volatility and find financial sector development can smoothen investment, consumption, diversify portfolios, manage production risks, generate information about the risks and returns of investments and then decrease growth volatility (Greenwood and Jovanovic, 1990; King and Levine, 1993, Obstfeld, 1994; Acemoglu and Ziliboti, 1997; Levine, 1997; Egert and Sutherland, 2014). Aghion et al. (1999), Caballero and Krishnamurty (2001) and Denizer et al. (2002) think that financial sector development can absorb economic shocks. Bernanke and Gertler $(1989,1990)$ and Kiyotaki and Moore (1997) document that market imperfections and restrictions can amplify macroeconomic shocks. Besides, Kunieda (2008), Beck et al. (2014), Wang et al. (2016) and Ibrahim and Alagidede (2017) point out that the impact of financial sector development on the growth 
volatility is nonlinear because of the financial leverage effect on the investment. Bacchetta and Caminal (2000) and Aghion et al. (2004) argue that the ultimate positive or negative effects of financial sector development on the volatility attribute to real or monetary shocks and a country's financial development level.

Combining several strands of the literature above, I investigate the following issues in this paper. The first is to examine the difference of the country-level annual growth volatility and its trend from 1997 to 2014, which is different from the long-term growth volatility by using several-year panels (Ferreira da Silva, 2002; Beck et al., 2006; Mangelli and Popov, 2015). The second issue is to explore whether financial sector development reduces growth volatility and the third is to examine whether financial sector development magnifies or dampens the shock of inflation volatility on the growth volatility in its different development levels. In order to answer the questions above, I collect the data in the 50 countries and apply the dynamic panel threshold model to investigate the nonlinear role of financial sector development on the growth volatility, regarding the shock from inflation volatility. Furthermore, I use several bank credit and health indicators to proxy financial sector development in this paper.

Overall, my empirical work shows that the aggregate growth volatility declines from 1997 to 2014 globally while the growth volatility in the advanced countries is much smaller than the volatility in the emerging countries. Financial sector development in the lower regime would reduce growth volatility. Furthermore, I find that financial sector 
development in the higher regime can magnify the shock of inflation volatility. Compared with the emerging countries, this magnifying effect of financial sector development is larger in the advanced countries.

The majority of literature explores the important roles financial sector development has on economic growth (Schumpeter, 1912; Greenwood and Jovanovic, 1990; King and Levine, 1993; Levine, 1997; Rajan and Zingales, 1998; Levine et al., 2000). Pagano (1993), Hasan et al. (2009) and Koetter and Wedow (2010) argue that bank quality can also reflect financial sector development, besides bank credit indicators. However, the investigation of the relationship between financial sector development and growth volatility is comparatively limited.

For the relationship between financial sector development and growth volatility, Levine (1997) finds that financial sector development could diminish growth volatility by diversifying portfolios, managing production risks, generating information about the risks and returns of alternative investments, which is helpful when allocating capital more efficiently. Greenwood and Jovanovic (1990), King and Levine (1993), Obstfeld (1994) and Acemoglu and Ziliboti (1997) think that the diversification not only encourages growth, but also reduces uncertainty since portfolio diversification can reduce aggregate risks. Furthermore, financial sector development would help to stabilize economic volatility by providing a broader scope of actions for monetary policy (Cecchetti and Krause, 2001), or allowing to smoothen consumption by relieving 
household liquidity constraints (Jappelli and Pistaferri, 2011). Denizer et al. (2002) point out that financial development leads to reductions in investment, consumption and output volatility.

In some empirical papers, Easterly et al. (2001) find that financial sector development permits a better management of risks and determines the stability of the economy. Ferreira da Silva (2002) reveals the cross-country evidence that the countries with more developed financial systems have smoother economic fluctuations. Braun and Larrain (2005) use the cross-country industry data and find that financial development lowers output volatility, especially in the financially vulnerable sectors. Dynan et al. (2006) find that financial development could stabilize economic activity, such as consumer spending, housing investment, and business fixed investment. Mangelli and Popov (2015) find that financial development could reduce the aggregate volatility in the OECD countries. Fernández et al. (2016) point out that banking stability could reduce the volatility of the value added of industries by using 110 countries' data.

Regarding whether financial sector development magnifies or dampens the economic shocks, Bernanke and Gertler $(1989,1990)$ and Kiyotaki and Moore (1997) find that macroeconomic shocks are magnified by credit market imperfections because information asymmetries and agency costs could reduce the borrower's ability to obtain credit so that business cycles exacerbates. Furthermore, they point out that the well developed financial system can dampen output volatility by removing or alleviating 
financial constraints. Similarly, Aghion et al. (1999), Caballero and Krishnamurty (2001)

and Denizer et al. (2002) find that the countries with well developed financial sector experience smaller output fluctuations since the developed financial sector can strengthen the economy's capacity to absorb shocks and then reduce cyclical fluctuations. Aghion et al. (2009) argue that financial market might be less effective to absorb the aggregate shocks and result in the higher growth volatility because of the various market imperfections and restrictions. Beck et al. (2006) conclude that financial intermediaries magnify the impacts of inflation volatility in the countries where firms have little or no access to external finance through the capital markets.

However, more access to the financial market might allow enterprises to increase financial leverage with higher risks, which might lead to the nonlinear relationship between financial sector development and volatility. Kunieda (2008) finds that the effect of financial sector development on volatility is concave. Output volatility is lower in the low financial development level, increases in the middle development level and then becomes lower again in the high financial development level. Arcand et al. (2012) and Dabla-Norris and Srivisal (2013) show that the relationship between financial development and volatility is U-shaped. They think that financial development acts as a shock absorber against volatility up to a point. Beyond this point, financial development might exacerbate shocks and increase volatility. In addition, Beck et al. (2014) use 77 countries' data in 1980-2007 and find that a developed financial sector stimulates growth 
at the cost of higher volatility in the high-income countries. Wang et al. (2016) find that financial development tends to have significantly lower aggregate volatility but the magnitude of volatility reduction diminishes quickly as the financial market develops further. The reason is that financial development relaxes collateral constraints and improves credit-allocation efficiency across firms. Ibrahim and Alagidede (2017) employ the 23 sub-Saharan African countries over the period 1980-2014 and confirm that the well developed financial sector dampens business cycle volatility while unbridled financial development may also magnify fluctuations.

Regarding whether financial sector development magnifies or dampens the effect of shocks on growth volatility, Bacchetta and Caminal (2000), Aghion et al. (2004) show that the ultimate positive or negative effects of financial development on the volatility depend on real or monetary shocks and a country's financial development level. Ferrante (2015) thinks the higher aggregate leverage of the banking system will amplify negative exogenous shocks through a mechanism, like the financial accelerator (see Bernanke et al., 1999; Gertler and Karadi, 2011). Ibrahim and Alagidede (2017) further show that the monetary shocks have a large magnifying effect on the volatility in the long-run business cycle but the reverse holds for the real shocks.

Reviewing the literature above, I find that there are limited empirical studies to investigate the nonlinear relationship with financial sector development and growth 
volatility and explore whether financial sector development could magnify or dampen the economic shocks in the global perspective. I believe my paper can fill this void.

\subsection{Empirical methodology and data}

\subsubsection{Regression models}

Kremer et al. (2013) propose the dynamic panel threshold model by extending the static panel threshold estimation (Hansen, 1999) and the cross-sectional threshold model with instrument variables (Caner and Hansen, 2004), where the generalized methods of moments (GMM) are used to handle endogeneity. Regarding the dynamic patterns of growth volatility, in this paper, I apply the dynamic panel threshold model to investigate two issues. The first is to explore whether financial sector development has the nonlinear effect on the growth volatility and the second is to examine whether financial sector development magnifies or damps the shock from inflation volatility. The two model specifications shown as:

$S D(G R O W T H)_{i t}=\alpha_{1} S D(G R O W T H)_{i t-1}+\alpha_{2} F D_{i t} * I\left(F D_{i t} \leq \lambda\right)+\delta_{1} I\left(F D_{i t} \leq \lambda\right)+\alpha_{3} F D_{i t} * I\left(F D_{i t}>\lambda\right)$ $+\alpha_{4} S D(\text { INFLATION })_{i t}+\alpha_{5} G D P_{i t}+\alpha_{6}$ TRADE $_{i t}+\alpha_{7} G O V_{i t}+\alpha_{8} R E C E_{i t}+\mu_{i}+\varepsilon_{i t}$

$S D(\text { GROWTH })_{i t}=\alpha_{1} S D(\text { GROWTH })_{i t-1}+\alpha_{2} F D_{i t}+\alpha_{3} S D(I N F L A T I O N)_{i t} * I\left(F D_{i t} \leq \lambda\right)+\delta_{1} I\left(F D_{i t} \leq \lambda\right)$ $+\alpha_{4} S D(I N F L A T I O N)_{i t} * I\left(F D_{i t}>\lambda\right)+\alpha_{5} G D P_{i t}+\alpha_{6} T_{R A D E_{i t}}+\alpha_{7} G O V_{i t}+\alpha_{8} R E C E_{i t}+\mu_{i}+\varepsilon_{i t}$

where $S D(G R O W T H)$ means growth volatility, defined as the standard deviation of real industrial production growth in constant 2010 US\$, SD(INFLATION) means inflation volatility, defined as the standard deviation of CPI. $F D$ refers to financial sector 
development. In this paper, I both use size and quality of bank credit to measure financial sector development. Four proxies for financial sector development include private credit by deposit money banks to GDP (private credit), bank credit to bank deposits (credit allocation), domestic credit to private sector of GDP (domestic credit) and banking health ratio (bank health) ${ }^{16}$.

In the control variables, GDP refers to log real gross domestic product in constant 2010 US\$ (economy size), TRADE refers to export and import as share of GDP (trade openness), GOV is government expenditure as share of GDP (government size) and RECE refer to the recession dummy ${ }^{17} \cdot \mu_{i}$ is the country-specific fixed effect and $\varepsilon_{i t}$ is the error term. $i$ and $t$ denote the index of country and time, respectively. The descriptions of the variables are shown in Table 3.1

In the regression models, financial sector development $(F D)$ is the threshold variable used to split the sample into two regimes and $\lambda$ is the unknown threshold parameter. $I(\cdot)$ is the indicator function, which takes the value 1 if the argument in parenthesis is valid, and 0 otherwise. This modelling strategy allows the roles of finance sector development to change in line with whether $F D$ is below or above some unknown level of $\lambda$.

\footnotetext{
${ }^{16}$ I also use liquid liabilities to GDP to proxy financial sector development but I find it is not significant to affect growth volatility.

17 The recession dummy indicates whether a country experiences the recession. I think that a recession occurs when cyclical output growth is more than one standard deviation below zero. After using the Hodrick-Prescott filter to remove the trend, I can obtain cyclical output growth. The smoothing parameter is 6.25 .
} 
Following Caner and Hansen (2004), there are three steps to estimate the specification coefficients. First, a reduced form regression is estimated for the endogenous variable, $X_{2 i t}$, as a function of the instruments, $Z_{i t}$ by the ordinary least square (OLS) and then obtain the fitted values of $\hat{X}_{2 i t}$. In this paper, I think the first lagged growth volatility is endogenous and I use more lagged growth volatility to become its instrument variables (Arellano and Bover, 1995). Following Roodman (2009), I only apply the second lagged growth volatility to be the instrument variable to avoid the overfitting problem.

Second, by substituting the predicted values of $\hat{X}_{2 i t}$ into the equation, the threshold parameter $\lambda$ can be estimated by the OLS and I donate the resulting sum of squared residuals by $S(\lambda)$. In the end, the estimator of the threshold value $\lambda$ is selected as the one associated with the smallest sum of squared residuals, $\hat{\lambda}=\arg \min S_{n}(\lambda)$.

In line with Hansen (2000) and Caner and Hansen (2004), the critical value to determine the $95 \%$ confidence interval of the threshold value is given by

$$
\Gamma=\{\lambda: L R(\lambda) \leq C(\alpha)\}
$$

where $C(\alpha)$ is the $95 \%$ of the asymptotic distribution of the likelihood ratio statistic $L R(\lambda)$. The underlying likelihood ratio is adjusted to account for the number of time periods used for each cross section (Hansen, 1999). Once the threshold value $(\hat{\lambda})$ is determined, the coefficients can be estimated by using the generalized methods of moments (GMM). 
Table 3.1 Variables and their meanings

\begin{tabular}{|c|c|}
\hline Variables & Meanings \\
\hline Growth volatility & Standard deviation of monthly real industrial production growth \\
\hline Inflation volatility & Standard deviation of monthly CPI \\
\hline \multirow{3}{*}{$\begin{array}{l}\text { Financial sector development } \\
\qquad(\text { Size })\end{array}$} & Private credit by deposit money banks to GDP (Private credit) \\
\hline & Bank credit to bank deposits (Credit allocation) \\
\hline & Domestic credit to private sector of GDP (Domestic credit) \\
\hline \multirow{5}{*}{$\begin{array}{l}\text { Financial sector development } \\
\text { (Quality) }\end{array}$} & Bank return on equity (before tax) (Profitability) \\
\hline & Bank regulatory capital to risk-weighted assets (Capital adequacy \\
\hline & ratio) \\
\hline & Bank nonperforming loans to gross loans (Bad loan ratio) \\
\hline & Bank Z-score \\
\hline Economy size & Log real gross domestic product \\
\hline Government size & Government expenditure/GDP \\
\hline Trade openness & Export and import/GDP \\
\hline Recession dummy & $\begin{array}{l}\text { The dummy equals to } 1 \text { when output growth is more than one } \\
\text { standard deviation below zero }\end{array}$ \\
\hline
\end{tabular}

\subsubsection{Data}

I collect the data from Global Economic Monitor (GEM), Global Financial Development Database (GFDD), World Development Indicators (WDI) and Datastream. The sample includes 50 countries and the sample period is from 1997 to $2014^{18}$. To be specific, I collect monthly seasonal adjusted real industrial production in constant 2010 US\$ and seasonal adjusted CPI from Global Economic Monitor database and collect monthly seasonal adjusted PPI from Datastream. I use the standard deviation of monthly real industrial production growth, CPI and PPI to represent annual growth volatility and inflation volatility without overlapping, respectively. This is different from the long-term

\footnotetext{
18 In order to keep the whole sample balanced, the starting year I select is 1997 and the sample does not include some advanced countries, including Australia, New Zealand, Canada and United Kindom.
} 
growth volatility using the several-year panels (Ferreira da Silva, 2002; Beck et al., 2006;

Mangelli and Popov, 2015). I also collect the annual financial sector development proxies from Global Financial Development Database, including private credit by deposit money banks to GDP, bank credit to bank deposits, domestic credit to private sector of GDP and banking health indicators.

Specifically, the banking health indicators include bank return on equity (before tax) (profitability), bank regulatory capital to risk-weighted assets (capital adequacy ratio), bank nonperforming loans to gross loans (bad loan ratio) and bank Z-score. Bank Z-score explicitly compares buffers (capitalization and returns) with risk (volatility of returns) to measure bank's solvency risk. It has a significant negative relationship with the probability of a financial institution's insolvency. The regulatory capital to risk-weighted assets and nonperforming loans to total gross loans measure the financial soundness. Therefore, I use the capital adequacy ratio, bad loan ratio and bank Z-score (financial stability proxies) and profitability to construct the banking health ratio ${ }^{19}$. I think that private credit by deposit money banks to GDP, bank credit to bank deposits and domestic credit to private sector of GDP can reflect the size of the financial sector development while the banking health ratio reflects the quality of the financial sector development.

I also collect the annual control variables from World Development Indicators database, including real gross domestic product (constant 2010 US\$) (economy size),

19 The component coefficients of the banking health ratio are 0.672 (profitability), -0.281 (capital adequacy ratio), -0.801 (bad loan ratio) and 0.518 (Z-score), respectively. 
export and import/GDP (trade openness) and general government final consumption expenditure/GDP (government size). The descriptive statistics could be found in Table 3.2 .

Table 3.2 shows that Denmark (1.45) has the largest private credit, followed by Iceland (1.38) and Japan (1.260) while Armenia (0.16), Gabon (0.10) and Venezuela (0.14) have the smaller private credit. Japan (1.92) has the largest domestic credit, followed by United States (1.805) and Denmark (1.46). Armenia (0.18), Gabon (0.11) and Venezuela (0.17) have the smaller domestic credit. Furthermore, China (2.73) has the largest credit allocation, followed by Denmark (2.71) and Sweden (2.21). Japan (0.61), Venezuela (0.69) and Philippines (0.35) have the smaller credit allocation. Regarding banking health, it is evident that the advanced countries have the healthier banking sectors than the developing countries. The bank Z-score shows that Austria (23.87), Israel (24.41) and United States (23.66) have more stable banking sectors. However, Ecuador (0.66), Indonesia (1.92) and Thailand (2.04) perform poorly in the banking stability ${ }^{20}$.

In the control variables, the United States (14033.00) has the larger economy size followed by Japan (5338.91) and China (4333.82) while the economy size of Malta (7.99), Armenia (7.55) and Macedonia (8.11) is smaller. Singapore (3.74), Ireland (1.68) and Malaysia (1.85) have the larger trade openness but the trade openness in Japan (0.27), the

\footnotetext{
${ }^{20}$ The banking sectors' specific performances include profitability, capital adequacy ratio and bad loan ratio. The details can be found in Table 2 .
} 
United States (0.26) and Bangladesh (0.36) is smaller. Furthermore, government size in Denmark (0.25), Sweden (0.25) and Israel (0.24) is larger. However, Bangladesh (0.05), Indonesia (0.08) and Philippines (0.11) have smaller government size. Singapore (4.00) and Venezuela (4.00) experience the longer recession periods but most western European countries experience the shorter recession periods, such as Austria (1.00), France (1.00) and Germany (1.00).

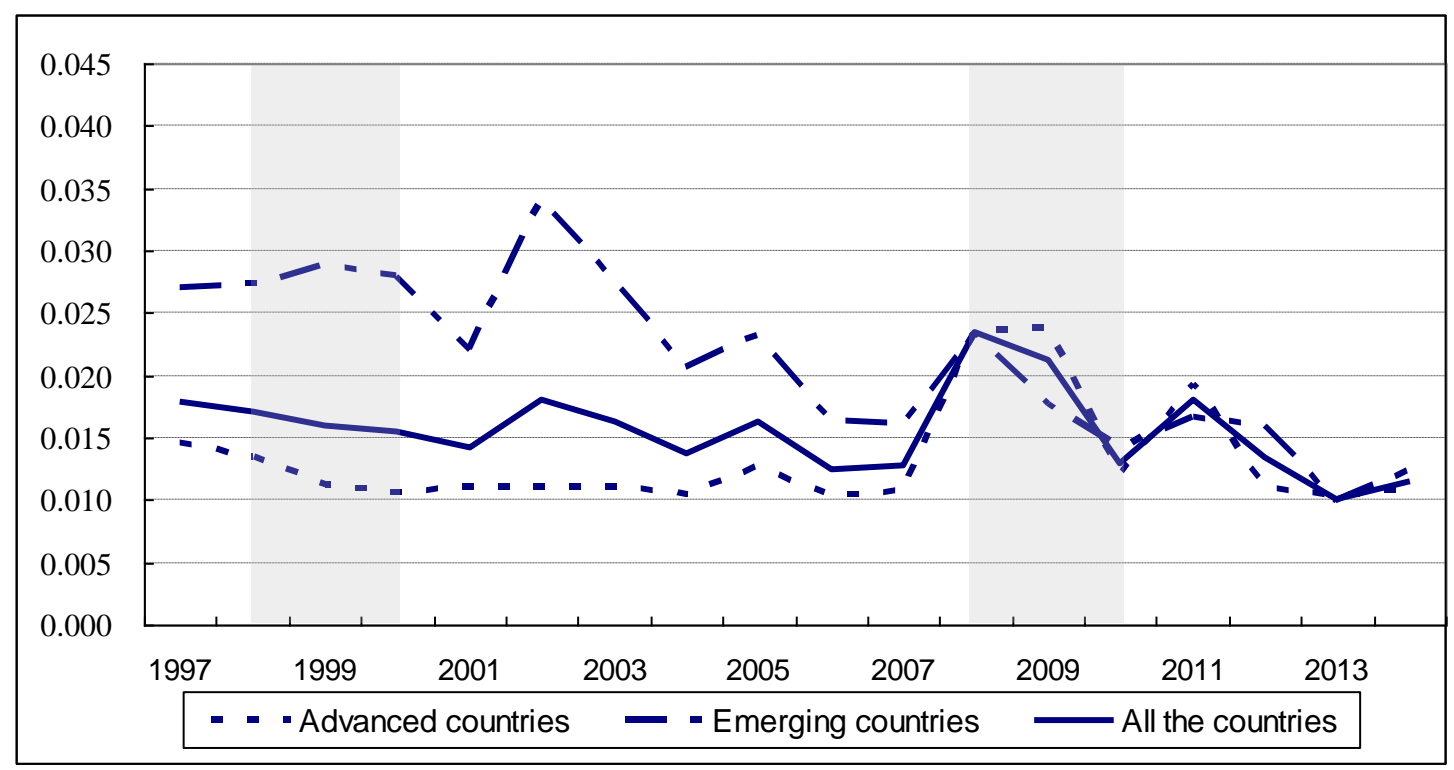

Figure 3.1 The trend of aggregate growth volatility from 1997 to 2014 Note: I calculate the country-level growth volatility by using 50 countries data year by year from 1997 to 2014 and then calculate the weighted average growth volatility to obtain the aggregate growth volatility for the advanced, emerging countries and all the countries, respectively. The weight is the real industrial production in constant 2010 US\$. The two shaded parts show the Asian financial crisis and 2008 global financial crisis, respectively. 
Table 3.2 Descriptive statistics in the 50 countries

\begin{tabular}{|c|c|c|c|c|c|c|c|c|c|c|c|c|c|c|}
\hline & $\begin{array}{c}\text { VOLAT } \\
\text { ILITY }\end{array}$ & $\begin{array}{c}\text { INFLAIT } \\
\text { ON }\end{array}$ & $\begin{array}{l}\text { PRIV } \\
\text { ATE }\end{array}$ & $\begin{array}{c}\text { CRED } \\
\text { EP }\end{array}$ & $\begin{array}{l}\text { DOME } \\
\text { SSTIC }\end{array}$ & $\begin{array}{c}\text { HEALT } \\
\mathrm{H}\end{array}$ & PROF & CAPT & BAD & $\begin{array}{c}\text { ZSCO } \\
\text { RE }\end{array}$ & SIZE & $\begin{array}{c}\text { TRA } \\
\text { DE }\end{array}$ & $\begin{array}{c}\mathrm{GO} \\
\mathrm{V}\end{array}$ & $\begin{array}{c}\text { REC } \\
\text { E }\end{array}$ \\
\hline \multicolumn{15}{|c|}{ Developed countries } \\
\hline Austria & 0.016 & 0.002 & 0.93 & 1.29 & 0.94 & 0.78 & 7.38 & 14.22 & 2.61 & 23.87 & 366.47 & 0.93 & 0.19 & 1.00 \\
\hline Belgium & 0.023 & 0.002 & 0.62 & 0.71 & 0.64 & 0.19 & 12.20 & 14.57 & 2.79 & 8.32 & 449.27 & 1.44 & 0.22 & 2.00 \\
\hline Czech & 0.024 & 0.003 & 0.44 & 0.77 & 0.43 & -0.39 & 14.85 & 14.02 & 8.60 & 3.69 & 182.61 & 1.17 & 0.20 & 2.00 \\
\hline Denmark & 0.037 & 0.002 & 1.45 & 2.71 & 1.46 & 0.31 & 11.27 & 14.47 & 2.23 & 9.83 & 311.31 & 0.89 & 0.25 & 1.00 \\
\hline Estonia & 0.032 & 0.003 & 0.59 & 1.51 & 0.18 & 0.19 & 14.50 & 17.73 & 1.75 & 8.23 & 18.48 & 1.42 & 0.19 & 3.00 \\
\hline Finland & 0.018 & 0.002 & 0.70 & 1.29 & 0.71 & 0.53 & 13.55 & 14.56 & 0.55 & 11.56 & 231.22 & 0.75 & 0.22 & 1.00 \\
\hline France & 0.014 & 0.002 & 0.85 & 1.25 & 0.86 & 0.19 & 8.10 & 12.38 & 4.25 & 11.82 & 2515.08 & 0.54 & 0.23 & 1.00 \\
\hline Germany & 0.014 & 0.002 & 1.01 & 1.46 & 1.00 & 0.27 & 5.67 & 13.98 & 3.77 & 15.31 & 3290.69 & 0.70 & 0.19 & 1.00 \\
\hline Greece & 0.030 & 0.003 & 0.73 & 0.90 & 0.76 & -0.90 & 0.92 & 12.10 & 12.29 & 3.50 & 277.62 & 0.54 & 0.20 & 3.00 \\
\hline Iceland & 0.033 & 0.003 & 1.38 & 2.14 & 1.44 & -0.27 & 16.47 & 15.32 & 4.98 & -0.77 & 12.12 & 0.83 & 0.24 & 3.00 \\
\hline Ireland & 0.057 & 0.002 & 1.09 & 1.31 & 1.12 & -0.05 & -0.12 & 14.13 & 6.80 & 4.12 & 199.01 & 1.68 & 0.17 & 2.00 \\
\hline Israel & 0.023 & 0.004 & 0.76 & 1.00 & 0.71 & 1.00 & 13.48 & 11.64 & 3.57 & 24.41 & 201.12 & 0.70 & 0.24 & 3.00 \\
\hline Italy & 0.012 & 0.001 & 0.74 & 1.24 & 0.76 & -0.14 & 6.67 & 11.55 & 9.32 & 12.81 & 2093.99 & 0.51 & 0.19 & 2.00 \\
\hline Japan & 0.018 & 0.007 & 1.26 & 0.61 & 1.92 & -0.02 & -0.03 & 12.29 & 3.62 & 10.72 & 5338.91 & 0.27 & 0.19 & 2.00 \\
\hline Malta & 0.035 & 0.004 & 1.06 & 0.84 & 1.38 & 0.12 & 15.36 & 15.37 & 7.48 & 15.56 & 7.99 & 2.58 & 0.19 & 3.00 \\
\hline Netherlands & 0.025 & 0.002 & 1.14 & 1.29 & 1.14 & 0.28 & 6.56 & 12.94 & 2.51 & 11.89 & 784.34 & 1.29 & 0.23 & 2.00 \\
\hline Portugal & 0.037 & 0.002 & 1.26 & 1.54 & 1.29 & 0.11 & 4.89 & 10.81 & 4.66 & 10.62 & 226.00 & 0.68 & 0.20 & 3.00 \\
\hline Singapore & 0.069 & 0.003 & 0.99 & 0.96 & 1.03 & 0.62 & 13.35 & 17.01 & 3.30 & 21.09 & 185.66 & 3.74 & 0.10 & 4.00 \\
\hline Slovakia & 0.042 & 0.004 & 0.42 & 0.85 & 0.37 & -0.30 & 8.58 & 14.95 & 8.29 & 11.16 & 74.50 & 1.44 & 0.19 & 2.00 \\
\hline Slovenia & 0.025 & 0.004 & 0.54 & 1.12 & 0.55 & -0.39 & 7.57 & 12.53 & 7.17 & 3.73 & 43.13 & 1.19 & 0.19 & 1.00 \\
\hline $\begin{array}{l}\text { South } \\
\text { Korea }\end{array}$ & 0.022 & 0.003 & 0.84 & 1.35 & 1.15 & 0.10 & 9.40 & 12.45 & 2.45 & 6.97 & 916.28 & 0.81 & 0.13 & 1.00 \\
\hline Spain & 0.013 & 0.002 & 1.26 & 1.52 & 0.23 & 0.43 & 9.48 & 12.17 & 3.19 & 13.87 & 1300.63 & 0.56 & 0.18 & 2.00 \\
\hline Sweden & 0.036 & 0.002 & 0.93 & 2.21 & 0.96 & 0.66 & 22.88 & 11.29 & 1.11 & 6.59 & 446.30 & 0.83 & 0.25 & 1.00 \\
\hline US & 0.006 & 0.002 & 0.51 & 0.74 & 1.81 & 1.12 & 16.34 & 13.36 & 2.03 & 23.66 & 14033.0 & 0.26 & 0.15 & 2.00 \\
\hline \multicolumn{15}{|c|}{ Developing countries } \\
\hline Armenia & 0.061 & 0.009 & 0.16 & 1.25 & 0.18 & -0.26 & 18.24 & 25.64 & 5.40 & 9.64 & 7.55 & 0.71 & 0.11 & 1.00 \\
\hline Bangladesh & 0.044 & 0.006 & 0.30 & 0.78 & 0.31 & -1.00 & 13.88 & 8.45 & 22.67 & 2.91 & 94.05 & 0.36 & 0.05 & 2.00 \\
\hline
\end{tabular}




\begin{tabular}{|c|c|c|c|c|c|c|c|c|c|c|c|c|c|c|}
\hline Bolivia & 0.042 & 0.005 & 0.43 & 1.00 & 0.48 & -0.01 & 11.47 & 13.37 & 7.52 & 10.59 & 16.98 & 0.65 & 0.15 & 2.00 \\
\hline Bulgaria & 0.026 & 0.027 & 0.41 & 0.87 & 0.41 & -0.98 & 15.24 & 22.06 & 9.23 & 4.54 & 43.32 & 1.01 & 0.18 & 2.00 \\
\hline Chile & 0.019 & 0.003 & 0.63 & 1.42 & 0.83 & 0.52 & 20.24 & 13.31 & 1.69 & 7.78 & 189.66 & 0.66 & 0.12 & 2.00 \\
\hline China & 0.007 & 0.003 & 1.10 & 2.73 & 1.18 & 0.65 & 19.49 & 7.333 & 9.53 & 20.11 & 4333.82 & 0.48 & 0.14 & 2.00 \\
\hline Colombia & 0.036 & 0.002 & 0.29 & 1.52 & 0.36 & -0.12 & 12.65 & 14.95 & 5.54 & 6.24 & 247.99 & 0.36 & 0.17 & 2.00 \\
\hline Ecuador & 0.030 & 0.007 & 0.23 & 1.10 & 0.23 & -0.57 & 13.20 & 15.87 & 8.50 & -0.66 & 61.35 & 0.55 & 0.12 & 2.00 \\
\hline Gabon & 0.056 & 0.008 & 0.10 & 0.71 & 0.11 & 0.26 & 23.20 & 18.36 & 9.09 & 10.67 & 14.02 & 0.89 & 0.14 & 3.00 \\
\hline Hungary & 0.024 & 0.003 & 0.44 & 1.01 & 0.43 & -0.11 & 16.48 & 13.74 & 6.68 & 4.88 & 122.98 & 1.40 & 0.21 & 2.00 \\
\hline India & 0.017 & 0.006 & 0.36 & 0.69 & 0.39 & 0.29 & 22.89 & 12.58 & 6.62 & 8.93 & 1260.28 & 0.40 & 0.11 & 3.00 \\
\hline Indonesia & 0.059 & 0.007 & 0.27 & 0.71 & 0.30 & -1.48 & 6.39 & 19.05 & 12.79 & 1.92 & 626.40 & 0.58 & 0.08 & 1.00 \\
\hline Latvia & 0.023 & 0.003 & 0.48 & 1.57 & 0.62 & -0.25 & 13.27 & 14.07 & 5.41 & 2.29 & 22.48 & 0.98 & 0.19 & 1.00 \\
\hline Macedonia & 0.055 & 0.006 & 0.30 & 1.12 & 0.31 & -1.37 & 8.57 & 20.21 & 15.75 & 7.28 & 8.11 & 0.93 & 0.19 & 3.00 \\
\hline Malaysia & 0.026 & 0.003 & 1.15 & 1.01 & 1.21 & -0.03 & 14.40 & 14.79 & 9.07 & 13.48 & 215.27 & 1.85 & 0.12 & 3.00 \\
\hline Mexico & 0.008 & 0.002 & 0.17 & 0.71 & 0.21 & 0.51 & 10.63 & 15.29 & 3.80 & 19.44 & 974.23 & 0.56 & 0.11 & 2.00 \\
\hline Lithuania & 0.060 & 0.003 & 0.32 & 1.14 & 0.27 & -0.71 & 8.93 & 14.92 & 9.67 & 3.50 & 33.72 & 1.17 & 0.20 & 2.00 \\
\hline Peru & 0.033 & 0.002 & 0.23 & 0.89 & 0.25 & 0.62 & 23.27 & 12.97 & 5.70 & 14.26 & 119.27 & 0.45 & 0.11 & 3.00 \\
\hline Philippines & 0.044 & 0.003 & 0.32 & 0.65 & 0.35 & 0.00 & 10.95 & 16.81 & 9.87 & 18.65 & 167.39 & 0.87 & 0.11 & 2.00 \\
\hline Poland & 0.021 & 0.002 & 0.35 & 0.86 & 0.34 & -0.32 & 12.87 & 13.58 & 9.49 & 7.20 & 404.45 & 0.73 & 0.18 & 3.00 \\
\hline Russia & 0.019 & 0.010 & 0.28 & 1.04 & 0.31 & -0.14 & 17.05 & 16.51 & 6.64 & 7.05 & 1287.99 & 0.55 & 0.18 & 2.00 \\
\hline $\begin{array}{l}\text { Saudi } \\
\text { Arabia }\end{array}$ & 0.022 & 0.002 & 0.32 & 1.57 & 0.34 & 0.21 & 18.00 & 19.09 & 4.55 & 12.62 & 438.15 & 0.77 & 0.23 & 3.00 \\
\hline Thailand & 0.042 & 0.004 & 1.09 & 1.09 & 1.17 & -1.13 & 6.39 & 13.95 & 11.91 & 2.04 & 287.78 & 1.24 & 0.14 & 3.00 \\
\hline Tunisia & 0.033 & 0.002 & 0.58 & 1.26 & 0.64 & -0.45 & 11.10 & 11.17 & 18.31 & 17.20 & 36.52 & 0.78 & 0.17 & 2.00 \\
\hline Venezuela & 0.070 & 0.007 & 0.14 & 0.69 & 0.17 & 0.69 & 30.46 & 15.99 & 3.65 & 9.78 & 348.61 & 0.50 & 0.13 & 4.00 \\
\hline $\begin{array}{l}\text { South } \\
\text { Africa }\end{array}$ & 0.022 & 0.003 & 0.68 & 1.22 & 1.37 & 1.01 & 20.03 & 13.37 & 3.41 & 21.19 & 328.47 & 0.57 & 0.19 & 2.00 \\
\hline
\end{tabular}

Note: VOLATILITY = Growth volatility, INFLAITON= Inflation volatility, PRIVATE $=$ Private credit, CREDEP $=$ Credit allocation, DOMESTIC = Domestic credit, HEALTH = Banking health, PROF = Profitability, CAPT = Capital adequacy ratio, BAD = Bad loan ratio, ZSCORE = Bank Z-score, SIZE $=$ Economy size, TRADE $=$ Trade openness, GOV = Government size, RECE $=$ Recession dummy (the number of recession periods in one country).

The unit of real GDP (constant 2010 US\$) is billion. 


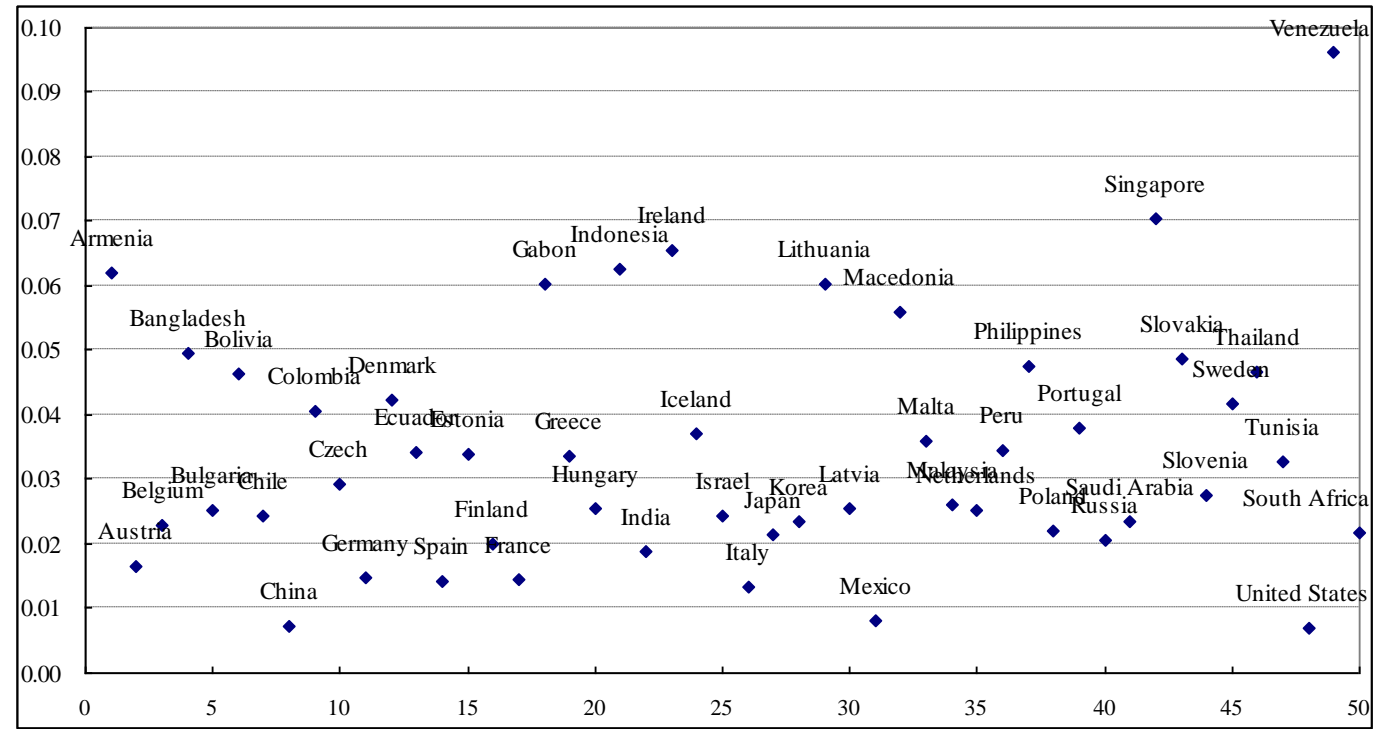

Figure 3.2 The country-level growth volatility of the 50 countries

Note: I calculate the average country-level growth volatility from 1997 to 2014 for each sample country

Figure 3.1 shows the trend of aggregate growth volatility of advanced, emerging and all the countries from 1997 to 2014. I observe that the aggregate growth volatility of all the countries declines from 1997 to 2014 but the aggregate growth volatility jumps up in the South American Economic Crisis (2002-2003), the Global Financial Crisis (2007-2009) and the European Debt Crisis (2010-2012). After dividing 50 countries into the advanced and emerging countries in line with World Economic Outlook (2013), I observe that the growth volatility of the emerging countries is much more fluctuating and larger than the advanced countries ${ }^{21}$. I argue that one of the reasons is that the poorly-developed financial sectors might exacerbate volatility because of the fewer

${ }^{21}$ Latvia starts to be regarded as the advanced country in World Economic Outlook (2014). I put Latvia in the emerging country group in line with World Economic Outlook (2013) since Latvia is thought as an emerging country in a long term. 
opportunities for firms to smooth investment shocks (Caballero and Krishnamurthy, 2001).

Furthermore, Figure 3.2 shows the country-level growth volatility of the 50 countries, where most emerging countries have larger growth volatility than advanced countries. To be specific, Venezuela (0.070), Singapore (0.069) and Armenia (0.061) have larger growth volatility. The United States (0.006), Mexico (0.008), China (0.007) and most western European countries have smaller growth volatility, like France (0.014), Italy (0.012), Spain (0.013) and Germany (0.014).

Table 3.3 shows the correlations of the variables used in this paper. It is evident that inflation volatility has a positive relationship with growth volatility. All the banking credit and health indicators are negatively related with growth volatility, including private credit, credit allocation, domestic credit and banking health. It demonstrates that financial sector development could diminish growth volatility. In the control variables, economy size and government size have negative relationships with growth volatility and trade openness positively affects growth volatility. Growth volatility becomes greater in the recession periods because of the positive relationship with recession dummy and growth volatility. 
Table 3.3 The correlations of the variables

\begin{tabular}{|c|c|c|c|c|c|c|c|c|c|c|}
\hline & VOLATILITY & INFLATION & PRVIATE & CREDEP & DOMESTIC & HEALTH & SIZE & TRADE & GOV & RECE \\
\hline VOLATILITY & 1.000 & & & & & & & & & \\
\hline INFLATION & 0.106 & 1.000 & & & & & & & & \\
\hline PRVIATE & -0.177 & -0.100 & 1.000 & & & & & & & \\
\hline CREDEP & -0.177 & -0.067 & 0.571 & 1.000 & & & & & & \\
\hline DOMESTIC & -0.229 & -0.097 & 0.856 & 0.411 & 1.000 & & & & & \\
\hline HEALTH & -0.218 & -0.177 & 0.038 & 0.037 & 0.149 & 1.000 & & & & \\
\hline SIZE & -0.372 & -0.087 & 0.254 & 0.030 & 0.394 & 0.257 & 1.000 & & & \\
\hline TRADE & 0.234 & -0.027 & 0.250 & -0.052 & 0.115 & 0.002 & -0.315 & 1.000 & & \\
\hline GOV & -0.196 & -0.104 & 0.364 & 0.321 & 0.272 & 0.075 & 0.035 & 0.026 & 1.000 & \\
\hline RECE & 0.092 & 0.037 & 0.072 & 0.014 & 0.032 & -0.103 & -0.032 & 0.017 & 0.030 & 1.000 \\
\hline
\end{tabular}

Note: VOLATILITY = Growth volatility, INFLATION $=$ Inflation volatility, PRIVATE $=$ Private credit, CREDEP $=$ Credit allocation, DOMESTIC $=$ Domestic credit, HEALTH $=$ Banking health, SIZE $=$ Economy size, TRADE $=$ Trade openness, GOV = Government size, RECE $=$ Recession dummy (the number of recession periods in one country). 


\subsection{Empirical results}

\subsubsection{The roles of financial sector development on the growth volatility}

Table 3.4 demonstrates that growth volatility has a significant positive first lagged autocorrelation, which means growth volatility has dynamic features. Furthermore, financial sector development has a significant negative effect on the growth volatility in this lower regime when I use credit allocation, domestic credit and banking health proxies. However, most bank credit and health indicators are not significant in the higher regime, except banking health. It shows that high financial sector development measured by bank credit size can not reduce growth volatility since the financial constraints for firms decrease and firms could increase financial leverage with higher risks. However, high financial sector development measured by banking health (quality variable) could reduce growth volatility without the threshold constraint. The threshold points for credit allocation, domestic credit and banking health are $0.601,1.307$ and 0.621 , respectively. The results support the nonlinear relationship with financial sector development and growth volatility (Kunieda, 2008; Beck et al., 2014; Wang et al., 2016; Ibrahim and Alagidede, 2017). 
Table 3.4 The results of the dynamic panel threshold models

\begin{tabular}{|c|c|c|c|c|}
\hline \multirow{2}{*}{ Growth volatility } & PRIVATE & CREDEP & DOMESTIC & HEALTH \\
\hline & Model 1 & Model 2 & Model 3 & Model 4 \\
\hline \multirow[t]{2}{*}{ Growth volatility $(-1)$} & $0.369^{* * *}$ & $0.363^{* * *}$ & $0.413^{* * *}$ & $0.447^{* * *}$ \\
\hline & $(0.065)$ & $(0.066)$ & $(0.064)$ & $(0.064)$ \\
\hline \multirow[t]{2}{*}{ FD in the lower regime } & 0.101 & $-0.042^{* * *}$ & $-0.011^{*}$ & $-0.002^{* *}$ \\
\hline & $(0.116)$ & $(0.012)$ & $(0.006)$ & $(0.001)$ \\
\hline \multirow[t]{2}{*}{ FD in the higher regime } & -0.007 & -0.004 & 0.009 & $-0.008^{* * *}$ \\
\hline & $(0.005)$ & $(0.003)$ & $(0.006)$ & $(0.003)$ \\
\hline \multirow[t]{2}{*}{ Inflation volatility } & $0.141^{* * * *}$ & $0.142^{* * *}$ & $0.134^{* * *}$ & $0.118^{* * *}$ \\
\hline & $(0.019)$ & $(0.018)$ & $(0.020)$ & $(0.019)$ \\
\hline \multirow[t]{2}{*}{ Economy size } & 0.002 & -0.001 & 0.001 & 0.001 \\
\hline & $(0.004)$ & $(0.004)$ & $(0.004)$ & $(0.004)$ \\
\hline \multirow[t]{2}{*}{ Trade openness } & $0.014^{* * *}$ & $0.013^{* * *}$ & $0.014^{* * *}$ & $0.011^{* * *}$ \\
\hline & $(0.004)$ & $(0.004)$ & $(0.004)$ & $(0.004)$ \\
\hline \multirow[t]{2}{*}{ Government size } & 0.039 & 0.033 & $0.075^{*}$ & 0.055 \\
\hline & $(0.042)$ & $(0.043)$ & $(0.043)$ & $(0.045)$ \\
\hline \multirow[t]{2}{*}{ Recession dummy } & 0.004 & 0.004 & 0.004 & 0.003 \\
\hline & $(0.003)$ & $(0.003)$ & $(0.003)$ & $(0.003)$ \\
\hline \multirow[t]{2}{*}{ Constant } & -0.003 & $0.032^{* * *}$ & $0.032^{* * * *}$ & $-0.010^{* * * *}$ \\
\hline & $(0.018)$ & $(0.007)$ & $(0.012)$ & $(0.003)$ \\
\hline Threshold point & 0.193 & 0.601 & 1.307 & 0.621 \\
\hline Confidence interval & $0.189-0.197$ & $0.590-0.992$ & $0.122-1.388$ & $-1.608-0.846$ \\
\hline Observations & 900 & 900 & 900 & 900 \\
\hline
\end{tabular}

Note: ${ }^{* * *},{ }^{* *}$ and ${ }^{*}$ show the significance at the level of $1 \%, 5 \%$ and $10 \%$, respectively. Standard error is provided in parentheses. The results are obtained by estimating Eq. (3.1). 
Table 3.5 The results of the dynamic panel threshold models in the advanced and emerging countries

\begin{tabular}{|c|c|c|c|c|c|c|c|c|}
\hline \multirow{3}{*}{ Growth volatility } & \multicolumn{4}{|c|}{ Advanced countries } & \multicolumn{4}{|c|}{ Emerging countries } \\
\hline & PRIVATE & CREDEP & DOMESTIC & HEALTH & PRIVATE & CREDEP & DOMESTIC & HEALTH \\
\hline & Model 1 & Model 2 & Model 3 & Model 4 & Model 5 & Model 6 & Model 7 & Model 8 \\
\hline \multirow[t]{2}{*}{ Growth volatility $(-1)$} & $0.676^{* * *}$ & $0.654^{* * *}$ & $0.657^{* * *}$ & $0.883^{* * *}$ & $0.193^{* *}$ & $0.187^{* *}$ & $0.229^{* * *}$ & $0.252^{* * *}$ \\
\hline & $(0.105)$ & $(0.106)$ & $(0.107)$ & $(0.096)$ & $(0.083)$ & $(0.089)$ & $(0.081)$ & $(0.081)$ \\
\hline \multirow[t]{2}{*}{ FD in the lower regime } & $-0.218^{* * *}$ & $-0.043^{* * *}$ & 0.056 & $-0.006^{* * *}$ & 0.095 & $-0.151^{* *}$ & $-0.106^{*}$ & $-0.003^{* * *}$ \\
\hline & $(0.070)$ & $(0.013)$ & $(0.038)$ & $(0.002)$ & $(0.115)$ & $(0.059)$ & $(0.055)$ & $(0.001)$ \\
\hline \multirow[t]{2}{*}{ FD in the higher regime } & -0.006 & $-0.010^{*}$ & -0.003 & -0.002 & 0.008 & -0.0002 & 0.007 & -0.006 \\
\hline & $(0.005)$ & $(0.006)$ & $(0.005)$ & $(0.004)$ & $(0.008)$ & $(0.003)$ & $(0.007)$ & $(0.005)$ \\
\hline \multirow[t]{2}{*}{ Inflation volatility } & $0.863^{*}$ & $0.919^{*}$ & 0.748 & 0.322 & $0.129^{* * * *}$ & $0.129^{* * *}$ & $0.087^{* * *}$ & $0.102^{* * *}$ \\
\hline & $(0.492)$ & $(0.521)$ & $(0.503)$ & $(0.510)$ & $(0.021)$ & $(0.021)$ & $(0.026)$ & $(0.020)$ \\
\hline \multirow[t]{2}{*}{ Economy size } & $0.021^{* *}$ & $0.015^{*}$ & $0.017^{*}$ & 0.013 & -0.005 & -0.007 & -0.005 & -0.006 \\
\hline & $(0.009)$ & $(0.008)$ & $(0.009)$ & $(0.008)$ & $(0.004)$ & $(0.005)$ & $(0.004)$ & $(0.005)$ \\
\hline \multirow[t]{2}{*}{ Trade openness } & $0.015^{* * *}$ & $0.014^{* * *}$ & $0.015^{* * *}$ & $0.016^{* * *}$ & 0.006 & 0.006 & -0.001 & 0.005 \\
\hline & $(0.005)$ & $(0.005)$ & $(0.005)$ & $(0.005)$ & $(0.006)$ & $(0.007)$ & $(0.006)$ & $(0.007)$ \\
\hline \multirow[t]{2}{*}{ Government size } & 0.028 & 0.006 & 0.026 & 0.015 & 0.004 & 0.035 & 0.013 & 0.034 \\
\hline & $(0.058)$ & $(0.059)$ & $(0.061)$ & $(0.060)$ & $(0.065)$ & $(0.069)$ & $(0.066)$ & $(0.069)$ \\
\hline \multirow[t]{2}{*}{ Recession dummy } & 0.003 & 0.003 & 0.002 & 0.001 & 0.005 & 0.005 & 0.004 & 0.004 \\
\hline & $(0.002)$ & $(0.002)$ & $(0.002)$ & $(0.002)$ & $(0.005)$ & $(0.005)$ & $(0.005)$ & $(0.004)$ \\
\hline \multirow[t]{2}{*}{ Constant } & $0.083^{* * *}$ & $0.020^{*}$ & 0.003 & -0.003 & 0.003 & $0.094^{* * *}$ & $0.024^{*}$ & $-0.009^{* *}$ \\
\hline & $(0.025)$ & $(0.011)$ & $(0.011)$ & $(0.004)$ & $(0.019)$ & $(0.036)$ & $(0.013)$ & $(0.004)$ \\
\hline Threshold point & 0.426 & 0.795 & 0.364 & 0.411 & 0.193 & 0.680 & 0.281 & -0.023 \\
\hline Confidence interval & $0.357-0.529$ & $0.571-1.181$ & $0.352-0.379$ & $-1.255-0.866$ & $0.189-0.211$ & $0.609-0.946$ & $0.110-0.407$ & $-1.938-0.721$ \\
\hline Observations & 432 & 432 & 432 & 432 & 468 & 0.187 & 468 & 468 \\
\hline
\end{tabular}

Note: ${ }^{* * *},{ }^{* *}$ and ${ }^{*}$ show the significance at the level of $1 \%, 5 \%$ and $10 \%$, respectively. Standard error is provided in parentheses. Results are obtained by estimating Eq. (3.1). 
Regarding the shock from inflation volatility, it is evident that inflation volatility significantly increases growth volatility, which is consistent with the findings from Beck et al. (2006) and Ibrahim and Alagidede (2017). In the control variables, trade openness significantly increases growth volatility. It shows that the countries with larger trade openness have more interactions with other countries so that they are easily influenced by the external shocks (Easterly et al., 2001; Kose et al., 2003; Claessens et al., 2012). I observe that government size is positively related with growth volatility since government intervention could be procyclical and magnify business cycles (Lane, 2003; Alesina et al., 2008). However, economy size and the recession dummy are not significant.

Regarding the large differences of the advanced and emerging countries, I split the whole sample into two sub-samples. Table 3.5 shows that the advanced and emerging countries have a significant positive first lagged autocorrelation in the growth volatility. The autocorrelation of growth volatility in the advanced countries is larger than emerging countries. Bank credit and health indicators negatively affect growth volatility in the both groups of countries in the lower regime. To be specific, private credit, credit allocation and banking health work well in the advanced countries while the credit allocation, domestic credit and banking health are significant in the emerging countries. Compared with the emerging countries, financial sector development in the advanced countries reduces growth volatility more. In addition, the threshold points in the advanced countries are higher than the emerging countries. It shows that it is easier for the emerging 
countries to reduce financial constraints and then diminish growth volatility. Furthermore, I observe that inflation volatility in the advanced countries has a large significant impact than emerging ones. Growth volatility is significantly influenced by trade openness in the advanced countries since the advanced countries have much larger trade openness than the emerging countries. Besides, economy size can significantly increase growth volatility in the advanced countries. Government size and the recession dummy are not significant for the advanced and emerging countries.

\subsubsection{The roles of financial sector development with the inflation volatility shock}

Regarding whether financial sector development might magnify or dampen economic shocks (Aghion et al., 1999; Caballero and Krishnamurty, 2001; Denizer et al., 2002; Aghion et al., 2004; Beck et al., 2006; Ibrahim and Alagidede, 2017), I run the regression models again with the inflation volatility shock. I investigate inflation volatility because inflation volatility can comprehensively reflect the effects of monetary policy and external nominal shocks, such as foreign exchange rate and oil price shocks. Table 3.6 shows that growth volatility has a significant positive first lagged autocorrelation pattern. Financial sector development has an expected significant negative effect on growth volatility, including credit allocation and banking health indicators.

Regarding the interaction effects of the inflation volatility with financial sector development, I observe that the interaction effects are significant positive for the growth 
volatility in the two regimes but the effects in the higher regime are significantly larger than the effects in the lower regime. Specifically, the coefficient of inflation volatility interacted with private credit in the lower regime is not significant but the coefficient is 0.142 in the higher regime. The coefficient of inflation volatility interacted with credit allocation is 0.118 in the lower regime while this coefficient is 1.390 in the higher regime. The coefficient of inflation volatility interacted with domestic credit is 0.121 in the lower regime while this coefficient is 0.574 in the higher regime. The coefficient of inflation volatility interacted with banking health is 0.101 in the lower regime and this coefficient is 1.086 in the higher regime. These findings support the conclusions from Arcand et al. (2012) and Dabla-Norris and Srivisal (2013). They find that financial development might absorb shocks against growth volatility up to a point. Beyond this point, financial development might exacerbate shocks and increase growth volatility. Beck et al. (2006) also argue that the excessive financial development can magnify the shock of inflation volatility on the growth volatility. Regarding the control variables, trade openness can increase growth volatility but economy size, government size and the recession dummy are not very significant.

Similarly, I divide the whole sample into two sub-samples in line with the advanced and emerging countries. Table 3.7 presents that growth volatility has a significant positive first lagged autocorrelation pattern in both countries but the positive autocorrelation is larger in the advanced countries. Financial sector development has a 
significant negative influence on the growth volatility in the both countries and its effect is more significant in the advanced countries. Specifically, credit allocation and banking health significantly reduce growth volatility in the advanced countries while only banking health works well to reduce growth volatility in the emerging countries.

Table 3.6 The results of the dynamic panel threshold models with interaction effects

\begin{tabular}{lcccc}
\hline \multirow{2}{*}{ Growth volatility } & PRIVATE & CREDEP & DOMESTIC & HEALTH \\
\cline { 2 - 5 } Growth volatility (-1) & Model 1 & Model 2 & Model 3 & Model 4 \\
FD & $0.355^{* * *}$ & $0.373^{* * *}$ & $0.408^{* * *}$ & $0.454^{* * *}$ \\
& $(0.065)$ & $(0.066)$ & $(0.065)$ & $(0.064)$ \\
Inflation volatility*I(FD in the & -0.007 & $-0.013^{* * *}$ & -0.002 & $-0.003^{* * *}$ \\
lower regime) & $(0.005)$ & $(0.004)$ & $(0.004)$ & $(0.001)$ \\
& 0.099 & $0.118^{* * *}$ & $0.121^{* * * *}$ & $0.101^{* * *}$ \\
Inflation volatility*I(FD in the & $(0.179)$ & $(0.015)$ & $(0.015)$ & $(0.015)$ \\
higher regime) & $0.142^{* * * *}$ & $1.390^{* * *}$ & $0.574^{* * *}$ & $1.086^{*}$ \\
Economy size & $(0.018)$ & $(0.429)$ & $(0.292)$ & $(0.576)$ \\
Trade openness & 0.003 & 0.001 & 0.001 & 0.002 \\
Government size & $(0.004)$ & $(0.004)$ & $(0.004)$ & $(0.004)$ \\
Recession dummy & $0.013^{* * *}$ & $0.012^{* * *}$ & $0.014^{* * * *}$ & $0.010^{* *}$ \\
Constant & $(0.004)$ & $(0.004)$ & $(0.004)$ & $(0.004)$ \\
& 0.038 & 0.058 & 0.050 & 0.046 \\
Threshold point & $(0.042)$ & $(0.043)$ & $(0.044)$ & $(0.044)$ \\
Confidence interval & 0.004 & 0.003 & 0.004 & 0.002 \\
Observations & $(0.003)$ & $(0.003)$ & $(0.003)$ & $(0.003)$ \\
\hline & $0.013^{* * *}$ & 0.001 & $0.008^{* * *}$ & -0.001 \\
& $(0.004)$ & $(0.003)$ & $(0.003)$ & $(0.002)$ \\
\hline & 0.193 & 1.010 & 0.425 & -0.023 \\
& $0.187-0.211$ & $0.601-1.265$ & $0.122-0.724$ & $-0.578-0.621$ \\
& 900 & 900 & 900 & 900 \\
\hline
\end{tabular}

Note: ${ }^{* * *},{ }^{* *}$ and ${ }^{*}$ show the significance at the level of $1 \%, 5 \%$ and $10 \%$, respectively. Standard error is provided in parentheses. The results are obtained by estimating Eq. (3.2). 
Table 3.7 The results of the dynamic panel threshold models with interaction effects in the advanced and emerging countries

\begin{tabular}{|c|c|c|c|c|c|c|c|c|}
\hline \multirow{3}{*}{ Growth volatility } & \multicolumn{4}{|c|}{ Advanced countries } & \multicolumn{4}{|c|}{ Developing countries } \\
\hline & PRIVATE & CREDEP & DOMESTIC & HEALTH & PRIVATE & CREDEP & DOMESTIC & HEALTH \\
\hline & Model 1 & Model 2 & Model 3 & Model 4 & Model 5 & Model 6 & Model 7 & Model 8 \\
\hline \multirow[t]{2}{*}{ Growth volatility $(-1)$} & $0.589^{* * *}$ & $0.623^{* * *}$ & $0.638^{* * *}$ & $0.916^{* * *}$ & $0.176^{* *}$ & $0.274^{* * * *}$ & $0.238^{* * *}$ & $0.267^{* * *}$ \\
\hline & $(0.114)$ & $(0.104)$ & $(0.106)$ & $(0.092)$ & $(0.083)$ & $(0.082)$ & $(0.081)$ & $(0.078)$ \\
\hline \multirow[t]{2}{*}{ FD } & -0.005 & $-0.015^{* * *}$ & -0.002 & $-0.005^{* * *}$ & 0.010 & 0.001 & 0.010 & $-0.004^{* * *}$ \\
\hline & $(0.005)$ & $(0.005)$ & $(0.005)$ & $(0.001)$ & $(0.008)$ & $(0.003)$ & $(0.007)$ & $(0.001)$ \\
\hline \multirow{2}{*}{$\begin{array}{l}\text { Inflation volatility*I(FD } \\
\text { in the lower regime) }\end{array}$} & -1.806 & -0.543 & -2.693 & 0.252 & 0.096 & $1.439^{*}$ & $0.104^{* * *}$ & $0.092^{* * *}$ \\
\hline & $(2.597)$ & $(0.454)$ & (2.193) & $(0.493)$ & $(0.199)$ & $(0.849)$ & $(0.020)$ & $(0.020)$ \\
\hline \multirow{2}{*}{$\begin{array}{l}\text { Inflation volatility*I(FD } \\
\text { in the higher regime) }\end{array}$} & $1.175^{* *}$ & $6.216^{* * *}$ & $1.109^{* *}$ & 2.726 & $0.132^{* * *}$ & $0.125^{* * *}$ & 0.194 & 1.172 \\
\hline & $(0.527)$ & $(1.217)$ & $(0.533)$ & (1.695) & $(0.018)$ & $(0.019)$ & $(0.292)$ & $(0.872)$ \\
\hline \multirow[t]{2}{*}{ Economy size } & $0.017^{*}$ & $0.015^{* *}$ & 0.011 & $0.013^{*}$ & -0.004 & -0.003 & -0.004 & -0.004 \\
\hline & $(0.009)$ & $(0.007)$ & $(0.008)$ & $(0.007)$ & $(0.004)$ & $(0.004)$ & $(0.005)$ & $(0.004)$ \\
\hline \multirow[t]{2}{*}{ Trade openness } & $0.014^{* * * *}$ & $0.012^{* *}$ & $0.015^{* * * *}$ & $0.015^{* * *}$ & 0.005 & 0.007 & 0.002 & 0.003 \\
\hline & $(0.005)$ & $(0.005)$ & $(0.005)$ & $(0.005)$ & $(0.006)$ & $(0.007)$ & $(0.007)$ & $(0.007)$ \\
\hline \multirow[t]{2}{*}{ Government size } & 0.044 & 0.084 & 0.047 & -0.004 & 0.005 & 0.030 & 0.018 & 0.043 \\
\hline & $(0.058)$ & $(0.055)$ & $(0.063)$ & $(0.060)$ & $(0.065)$ & $(0.067)$ & $(0.065)$ & $(0.069)$ \\
\hline \multirow[t]{2}{*}{ Recession dummy } & 0.003 & 0.001 & 0.002 & 0.001 & 0.005 & 0.004 & 0.005 & 0.004 \\
\hline & $(0.002)$ & $(0.002)$ & $(0.002)$ & $(0.002)$ & $(0.005)$ & $(0.004)$ & $(0.005)$ & $(0.004)$ \\
\hline \multirow[t]{2}{*}{ Constant } & $0.026^{* *}$ & $0.018^{* * * *}$ & $0.028^{* * *}$ & 0.0002 & $0.016^{* * *}$ & 0.002 & $0.011^{* * * *}$ & -0.003 \\
\hline & $(0.011)$ & $(0.006)$ & $(0.010)$ & $(0.004)$ & $(0.005)$ & $(0.006)$ & $(0.004)$ & $(0.004)$ \\
\hline Threshold point & 0.379 & 1.036 & 0.379 & 0.701 & 0.193 & 0.707 & 0.216 & -0.023 \\
\hline Confidence interval & $0.362-0.392$ & $1.000-1.134$ & $0.352-0.388$ & $-1.255-0.866$ & $0.187-0.211$ & $0.609-0.712$ & $0.110-0.971$ & $-0.613-0.023$ \\
\hline Observations & 432 & 432 & 432 & 432 & 468 & 468 & 468 & 468 \\
\hline
\end{tabular}


Considering the interaction effects of inflation volatility with financial sector development, I find that the interaction effects are significant and positive for the growth volatility in the two regimes in the advanced and emerging countries. Specifically, in the advanced countries, the influence in the higher regime is significantly larger than the influence in the lower regime. The magnifying effect of financial sector development in the higher regime is not very significant in the emerging countries. This finding shows that most advanced countries have more developed financial sectors, effectively transmit monetary policies and magnify the nominal volatility shock, compared with the emerging countries. Bernanke and Gertler (1995) also argue that bank lending (credit channel) might play an important role in the amplification and propagation of monetary policy shocks to real variables. In the control variables, in the advanced countries, economy size and trade openness have positive significant influences on the growth volatility but government size and the recession dummy are not significant.

\subsection{Robustness tests}

\subsubsection{Additional control and alternative variables}

Easterly et al. (2001), Kose et al. (2003) and Calderón and Schmidt-Hebbel (2008) document the significant connections with financial openness and macroeconomic volatility. In order to distinguish the effects of financial sector development and financial openness (liberalization) on the growth volatility, I collect the Chinn-Ito index (Chinn and 
Ito 2006) to proxy financial openness and add it in the regression model. Table 3.8 shows that most variables keep their expected influences, including the first lagged growth volatility, financial sector development, the inflation volatility shock and the control variables. Using domestic credit to proxy financial sector development, I observe that financial sector development in the higher regime could increase growth volatility. Financial openness negatively affects growth volatility. Using banking health to proxy financial sector development, banking health and financial openness both have significant negative impacts on growth volatility. It supports that financial openness and financial sector development have their distinct roles on diminishing growth volatility.

Furthermore, Acemoglu et al. (2003) and Tang et al. (2008) argue technology progress and institution quality can stabilize growth volatility. In order to investigate the effects of technology progress and institution quality on the growth volatility, I collect the theoretical duration of secondary education (years) to show the education investment and use the mortality rate to reflect the high-tech medical treatment and public health measures $^{22}$. Both indicators can proxy for human capital investment and technological progress (Kalemli-Ozcan, 2002, 2003). In the second transmission channel, human capital could promote technological progress, increase economic growth and then reduce growth volatility since there is a significant negative connection with volatility and economic

\footnotetext{
${ }^{22}$ I collect the theoretical duration of secondary education (years) and the mortality rate from World Development Indicators database.
} 
growth (Ramey and Ramey, 1995; Aghion et al., 2004). Meanwhile, I collect "Law and Order" in the International Country Risk Guide (ICRG) to show law and institution quality (Agrast et al., 2013) ${ }^{23}$.

Using domestic credit as a proxy for financial sector development, I observe that the theoretical duration of secondary education (years) and the mortality rate have significant negative influences on the growth volatility since the large human capital accumulation could promote technology progress, economic growth and reduce growth volatility. The rule of law also has a significant negative influence on the growth volatility. It means that law and institution quality can diminish growth volatility since it provides a good regulation and environment for financial development. While using banking health as a proxy for financial sector development, I find that the mortality rate and the rule of law also have negative relationships with growth volatility.

23 "Law and Order" is a single component but its two elements are assessed separately, with each element being scored from zero to three points. To assess the "Law" element, the strength and impartiality of the legal system are considered, while the "Order" element is an assessment of popular observance of the law. Thus, a country can have a high rating 3 in terms of its judicial system, but have a low rating 1 if it suffers from a very high crime rate or the law is routinely ignored without effective sanction. 
Table 3.8 The results of the dynamic panel threshold models with additional control variables

\begin{tabular}{|c|c|c|c|c|c|c|c|c|}
\hline \multirow{2}{*}{ Growth volatility } & \multicolumn{4}{|c|}{ DOMESTIC } & \multicolumn{4}{|c|}{ HEALTH } \\
\hline & Model 1 & Model 2 & Model 3 & Model 4 & Model 5 & Model 6 & Model 7 & Model 8 \\
\hline \multirow[t]{2}{*}{ Growth volatility (-1) } & $0.438^{* * * *}$ & $0.411^{* * * *}$ & $0.415^{* * *}$ & $0.392^{* * * *}$ & $0.470^{* * * *}$ & $0.443^{* * * *}$ & $0.445^{* * * *}$ & $0.431^{* * *}$ \\
\hline & $(0.062)$ & $(0.065)$ & $(0.065)$ & $(0.066)$ & $(0.061)$ & $(0.064)$ & $(0.064)$ & $(0.065)$ \\
\hline \multirow[t]{2}{*}{ FD in the lower regime } & -0.010 & $-0.015^{*}$ & -0.014 & $-0.073^{*}$ & $-0.002^{* *}$ & $-0.002^{* *}$ & $-0.003^{* * *}$ & $-0.003^{* * * *}$ \\
\hline & $(0.007)$ & $(0.009)$ & $(0.009)$ & $(0.041)$ & $(0.001)$ & $(0.001)$ & $(0.001)$ & $(0.001)$ \\
\hline \multirow[t]{2}{*}{ FD in the higher regime } & $0.011^{*}$ & 0.000 & 0.002 & -0.003 & $-0.008^{* * * *}$ & $-0.008^{* *}$ & $-0.007^{* *}$ & $-0.008^{* * *}$ \\
\hline & $(0.006)$ & $(0.004)$ & $(0.004)$ & $(0.005)$ & $(0.003)$ & $(0.003)$ & $(0.003)$ & $(0.003)$ \\
\hline \multirow[t]{2}{*}{ Inflation volatility } & $0.122^{* * * *}$ & $0.113^{* * * *}$ & $0.124^{* * *}$ & $0.123^{* * *}$ & $0.106^{* * *}$ & $0.111^{* * *}$ & $0.115^{* * *}$ & $0.121^{* * *}$ \\
\hline & $(0.019)$ & $(0.023)$ & $(0.022)$ & $(0.022)$ & $(0.019)$ & $(0.019)$ & $(0.018)$ & $(0.018)$ \\
\hline \multirow[t]{2}{*}{ Economy size } & 0.002 & 0.002 & -0.007 & -0.003 & 0.002 & 0.001 & -0.008 & -0.001 \\
\hline & $(0.004)$ & $(0.004)$ & $(0.006)$ & $(0.004)$ & $(0.004)$ & $(0.004)$ & $(0.006)$ & $(0.004)$ \\
\hline \multirow[t]{2}{*}{ Trade openness } & $0.017^{* * *}$ & $0.012^{* * *}$ & $0.016^{* * *}$ & $0.008^{* *}$ & $0.014^{* * *}$ & $0.010^{* *}$ & $0.014^{* * *}$ & $0.009^{* *}$ \\
\hline & $(0.004)$ & $(0.004)$ & $(0.004)$ & $(0.004)$ & $(0.004)$ & $(0.004)$ & $(0.004)$ & $(0.004)$ \\
\hline \multirow[t]{2}{*}{ Government size } & $0.073^{*}$ & 0.061 & 0.041 & 0.065 & 0.055 & 0.056 & 0.042 & 0.055 \\
\hline & $(0.044)$ & $(0.045)$ & $(0.045)$ & $(0.044)$ & $(0.045)$ & $(0.045)$ & $(0.045)$ & $(0.044)$ \\
\hline \multirow[t]{2}{*}{ Recession dummy } & 0.004 & 0.004 & 0.004 & 0.003 & 0.003 & 0.002 & 0.003 & 0.003 \\
\hline & $(0.003)$ & $(0.003)$ & $(0.003)$ & $(0.003)$ & $(0.003)$ & $(0.003)$ & $(0.003)$ & $(0.003)$ \\
\hline \multirow[t]{2}{*}{ Financial openness } & -0.009 & & & & $-0.009^{*}$ & & & \\
\hline & $(0.006)$ & & & & $(0.005)$ & & & \\
\hline \multirow[t]{2}{*}{ Duration of secondary education } & & $-0.007^{* *}$ & & & & -0.004 & & \\
\hline & & $(0.003)$ & & & & $(0.003)$ & & \\
\hline \multirow[t]{2}{*}{ Mortality rate } & & & $-0.038^{* *}$ & & & & $-0.043^{* * *}$ & \\
\hline & & & $(0.016)$ & & & & $(0.015)$ & \\
\hline \multirow[t]{2}{*}{ Rule of law } & & & & $-0.004^{* *}$ & & & & $-0.004^{* * *}$ \\
\hline & & & & $(0.002)$ & & & & $(0.002)$ \\
\hline
\end{tabular}




\begin{tabular}{|c|c|c|c|c|c|c|c|c|}
\hline Constant & $\begin{array}{l}0.032^{* * *} \\
(0.012)\end{array}$ & $\begin{array}{l}0.017^{* * *} \\
(0.006)\end{array}$ & $\begin{array}{l}0.016^{* * *} \\
(0.006)\end{array}$ & $\begin{array}{c}0.013 \\
(0.009)\end{array}$ & $\begin{array}{l}-0.009^{* * *} \\
(0.003)\end{array}$ & $\begin{array}{l}-0.010^{* * *} \\
(0.003)\end{array}$ & $\begin{array}{l}-0.009^{* * *} \\
(0.003)\end{array}$ & $\begin{array}{c}-0.009^{* * *} \\
(0.003)\end{array}$ \\
\hline Threshold point & 1.307 & 0.694 & 0.694 & 0.281 & 0.621 & 0.621 & 0.621 & 0.613 \\
\hline Confidence interval & $0.123-1.385$ & $0.167-1.385$ & $0.123-1.385$ & $0.123-1.385$ & $-1.603-0.844$ & $-1.603-0.843$ & $-1.603-0.844$ & $-1.603-0.843$ \\
\hline Observations & 900 & 900 & 900 & 900 & 900 & 900 & 900 & 900 \\
\hline
\end{tabular}

Note: ${ }^{* * *},{ }^{* *}$ and ${ }^{*}$ show the significance at the level of $1 \%, 5 \%$ and $10 \%$, respectively. Standard error is provided in parentheses. The regression model is shown as:

$S D(G R O W T H)_{i t}=\alpha_{1} S D(G R O W T H)_{i t-1}+\alpha_{2} F D_{i t} * I\left(F D_{i t} \leq \lambda\right)+\delta_{1} I\left(F D_{i t} \leq \lambda\right)+\alpha_{3} F D_{i t} * I\left(F D_{i t}>\lambda\right)+\alpha_{4} S D(I N F L A T I O N)_{i t}+\alpha_{5} G D P_{i t}+\alpha_{6} T R A D E_{i t}+\alpha_{7} G O V_{i t}+\alpha_{8} R E C E_{i t}+a_{9} O P E N$ $+a_{10} E D U_{i t}+a_{11} L A W_{i t}+a_{12}$ MORTALITY $_{i t}+\mu_{i}+\varepsilon_{i t}$ 
Table 3.9 The results of the dynamic panel threshold models with interaction effects of PPI volatility

\begin{tabular}{lcccc}
\hline \multirow{2}{*}{ Growth volatility } & PRIVATE & CREDEP & DOMESTIC & HEALTH \\
\cline { 2 - 5 } Growth volatility (-1) & Model 1 & Model 2 & Model 3 & Model 4 \\
\hline FD & $0.345^{* * *}$ & $0.327^{* * *}$ & $0.417^{* * *}$ & $0.471^{* * *}$ \\
& $(0.075)$ & $(0.074)$ & $(0.072)$ & $(0.072)$ \\
Inflation volatility *I(FD in & $-0.012^{* *}$ & $-0.019^{* * *}$ & -0.004 & $-0.003^{* * *}$ \\
the lower regime) & $(0.006)$ & $(0.005)$ & $(0.005)$ & $(0.001)$ \\
& -0.059 & 0.020 & 0.123 & 0.054 \\
Inflation volatility *I (FD in & $(0.437)$ & $(0.303)$ & $(0.200)$ & $(0.154)$ \\
the higher regime) & $0.414^{* * * *}$ & $0.360^{* *}$ & $0.491^{* *}$ & $0.483^{* * *}$ \\
& $(0.143)$ & $(0.152)$ & $(0.197)$ & $(0.147)$ \\
Economy size & -0.005 & $-0.014^{* *}$ & -0.009 & $-0.010^{*}$ \\
Trade openness & $(0.006)$ & $(0.006)$ & $(0.006)$ & $(0.006)$ \\
Government size & 0.008 & 0.008 & $0.010^{*}$ & 0.008 \\
Recession dummy & $(0.005)$ & $(0.005)$ & $(0.006)$ & $(0.006)$ \\
Constant & -0.034 & 0.024 & -0.005 & -0.010 \\
& $(0.061)$ & $(0.062)$ & $(0.062)$ & $(0.061)$ \\
Threshold point & 0.004 & 0.002 & 0.002 & 0.001 \\
Confidence interval & $(0.003)$ & $(0.002)$ & $(0.002)$ & $(0.003)$ \\
\hline Observations & $0.018^{* *}$ & $-0.008^{* *}$ & $0.011^{* *}$ & -0.0005 \\
& $(0.007)$ & $(0.004)$ & $(0.004)$ & $(0.002)$ \\
\hline & 0.192 & 0.992 & 0.352 & 0.109 \\
& $0.179-1.018$ & $0.940-1.016$ & $0.220-1.473$ & $-1.475-0.831$ \\
& 540 & 540 & 540 & 540 \\
\hline
\end{tabular}

Note: ${ }^{* * *},{ }^{* *}$ and ${ }^{*}$ show the significance at the level of $1 \%, 5 \%$ and $10 \%$, respectively. Standard error is provided in parentheses. I use PPI volatility to represent the inflation volatility shock. The results are obtained by estimating Eq. (3.2).

Robustly, I use PPI volatility to reflect inflation volatility ${ }^{24}$, which is defined as the standard deviation of PPI. Table 3.9 shows that the effect of first lagged growth volatility is significant and positive. Financial sector development has a significant and negative

${ }^{24}$ I also obtain the significant positive effect of inflation volatility on the growth volatility when I estimate the Eq. (3.1) by using PPI volatility to represent the inflation volatility shock. I do not report the results because of the limitations of space. 
effect on the growth volatility, by using the proxies like private credit, credit allocation and banking health. In the interaction effects of inflation volatility with financial sector development, it is evident that inflation volatility has a significant positive influence on the growth volatility in the higher regime but its influence is not significant in the lower regime. It supports the previous conclusion again that excessive financial sector development might magnify the inflation volatility shock (see Beck et al., 2006 Arcand et al., 2012; Dabla-Norris and Srivisal, 2013). In the control variables, economy size negatively affects growth volatility and trade openness positively affects growth volatility, respectively. However, government size and the recession dummy are not significant.

\subsubsection{Tests on the endogeneity of inflation volatility}

Since growth volatility and inflation volatility are codetermined, which might result in endogeneity, I use the first lagged inflation volatility to replace inflation volatility and use the central bank assets to GDP as an instrument variable (IV) to be robustness tests, respectively. After I use the first lagged inflation volatility to substitute inflation volatility and estimate Eq. (3.1), Table 3.10 demonstrates that growth volatility has a significant first lagged positive autocorrelation pattern. Financial sector development significantly reduces growth volatility in the lower regime. Inflation volatility has a significant positive impact on the growth volatility. The control variables keep their expected effects. Furthermore, using the central bank assets to GDP to be an instrument variable for 
inflation volatility, I observe that inflation volatility also has a significant positive impact on the growth volatility and the other variables kept their expected influences as above. These show that the negative relationship of financial sector development and growth volatility in the lower regime is very robust.

To test whether financial sector development magnifies or dampens the effect of inflation volatility on the growth volatility, I use the first lagged inflation volatility to replace inflation volatility and then estimate Eq. (3.2). Table 3.11 exhibits the interaction of inflation volatility with financial sector development has a positive influence on the growth volatility in the two regimes but its influence in the higher regime is significantly larger than that in the lower regime. Regarding the central bank assets to GDP to be an instrument variable for inflation volatility, I observe the interaction of inflation volatility with financial sector development has a positive influence on growth volatility in two regimes but I do not find its influences in the higher regime are significantly larger than that in the lower regime. The other variables keep their expected effects as above. In summary, I confirm that the results I obtain in this paper are very robust after taking endogeneity into consideration. 
Table 3.10 The results of the dynamic panel threshold models using more instrument variables

\begin{tabular}{|c|c|c|c|c|c|c|c|c|}
\hline \multirow{3}{*}{ Growth volatility } & \multicolumn{4}{|c|}{ Inflation volatility $=$ The first lagged inflation volatility } & \multicolumn{4}{|c|}{ Inflation volatility = Central bank assets to GDP (IV) } \\
\hline & PRIVATE & CREDEP & DOMESTIC & HEALTH & PRIVATE & CREDEP & DOMESTIC & HEALTH \\
\hline & Model 1 & Model 2 & Model 3 & Model 4 & Model 1 & Model 2 & Model 3 & Model 4 \\
\hline \multirow[t]{2}{*}{ Growth volatility $(-1)$} & $0.355^{* * *}$ & $0.348^{* * *}$ & $0.398^{* * *}$ & $0.432^{* * *}$ & $0.365^{* * *}$ & $0.370^{* * *}$ & $0.408^{* * *}$ & $0.453^{* * *}$ \\
\hline & $(0.065)$ & $(0.067)$ & $(0.065)$ & $(0.065)$ & $(0.068)$ & $(0.070)$ & $(0.066)$ & $(0.064)$ \\
\hline \multirow[t]{2}{*}{ FD in the lower regime } & 0.113 & $-0.042^{* * *}$ & -0.016 & $-0.003^{* * *}$ & 0.101 & $-0.104^{* *}$ & $-0.080^{*}$ & $-0.003^{* * *}$ \\
\hline & $(0.122)$ & $(0.012)$ & $(0.010)$ & $(0.001)$ & $(0.131)$ & $(0.045)$ & $(0.045)$ & $(0.001)$ \\
\hline \multirow[t]{2}{*}{ FD in the higher regime } & -0.007 & -0.005 & 0.0004 & $-0.008^{* * *}$ & -0.003 & -0.005 & -0.0005 & $-0.009^{* * *}$ \\
\hline & $(0.005)$ & $(0.003)$ & $(0.004)$ & $(0.003)$ & $(0.005)$ & $(0.004)$ & $(0.005)$ & $(0.003)$ \\
\hline \multirow[t]{2}{*}{ Inflation volatility } & $0.074^{*}$ & $0.049^{*}$ & $0.075^{* * *}$ & $0.059^{* *}$ & $1.216^{*}$ & 0.780 & $1.720^{* *}$ & $1.536^{* *}$ \\
\hline & $(0.040)$ & $(0.027)$ & $(0.029)$ & $(0.027)$ & $(0.674)$ & $(0.719)$ & $(0.695)$ & $(0.684)$ \\
\hline \multirow[t]{2}{*}{ Economy size } & 0.0003 & -0.003 & 0.0004 & 0.0001 & 0.002 & -0.002 & 0.0001 & 0.003 \\
\hline & $(0.004)$ & $(0.004)$ & $(0.004)$ & $(0.004)$ & $(0.004)$ & $(0.004)$ & $(0.004)$ & $(0.005)$ \\
\hline \multirow[t]{2}{*}{ Trade openness } & $0.014^{* * *}$ & $0.013^{* * *}$ & $0.013^{* * *}$ & $0.011^{* * *}$ & $0.013^{* * *}$ & $0.012^{* * *}$ & $0.010^{* *}$ & $0.011^{* * *}$ \\
\hline & $(0.004)$ & $(0.004)$ & $(0.004)$ & $(0.004)$ & $(0.004)$ & $(0.004)$ & $(0.004)$ & $(0.004)$ \\
\hline \multirow[t]{2}{*}{ Government size } & 0.024 & 0.015 & 0.041 & 0.041 & -0.008 & 0.004 & 0.020 & 0.016 \\
\hline & $(0.045)$ & $(0.046)$ & $(0.047)$ & $(0.047)$ & $(0.050)$ & $(0.051)$ & $(0.051)$ & $(0.052)$ \\
\hline \multirow[t]{2}{*}{ Recession dummy } & $0.005^{*}$ & 0.004 & 0.004 & 0.003 & $0.005^{*}$ & 0.004 & 0.004 & 0.003 \\
\hline & $(0.003)$ & $(0.003)$ & $(0.003)$ & $(0.003)$ & $(0.003)$ & $(0.003)$ & $(0.003)$ & $(0.003)$ \\
\hline \multirow[t]{2}{*}{ Constant } & -0.006 & $0.031^{* * *}$ & $0.016^{* * *}$ & $-0.009^{* * *}$ & -0.001 & $0.061^{* *}$ & 0.014 & $-0.011^{* * *}$ \\
\hline & $(0.020)$ & $(0.007)$ & $(0.006)$ & $(0.003)$ & $(0.021)$ & $(0.026)$ & $(0.009)$ & $(0.003)$ \\
\hline Threshold point & 0.193 & 0.601 & 0.694 & 0.621 & 0.192 & 0.680 & 0.281 & 0.621 \\
\hline Confidence interval & $0.189-0.197$ & $0.590-0.992$ & $0.122-1.388$ & $-1.608-0.846$ & $0.189-0.197$ & $0.581-1.164$ & $0.116-1.419$ & $-1.638-0.721$ \\
\hline Observations & 900 & 900 & 900 & 900 & 900 & 900 & 900 & 900 \\
\hline
\end{tabular}

Note: ${ }^{* * * * *}$ and ${ }^{*}$ show the significance at the level of $1 \%, 5 \%$ and $10 \%$, respectively. Standard error is provided in parentheses. The results are obtained by Eq. (3.1). 
Table 3.11 The results of the dynamic panel threshold models with interaction effects using more instrument variables

\begin{tabular}{|c|c|c|c|c|c|c|c|c|}
\hline \multirow{3}{*}{ Growth volatility } & \multicolumn{4}{|c|}{ Inflation volatility $=$ The first lagged inflation volatility } & \multicolumn{4}{|c|}{ Inflation volatility $=$ Central bank assets to GDP (IV) } \\
\hline & PRIVATE & CREDEP & DOMESTIC & HEALTH & PRIVATE & CREDEP & DOMESTIC & HEALTH \\
\hline & Model 1 & Model 2 & Model 3 & Model 4 & Model 1 & Model 2 & Model 3 & Model 4 \\
\hline Growth volatility $(-1)$ & $0.326^{* * *}$ & $0.344^{* * *}$ & $0.393^{* * *}$ & $0.425^{* * *}$ & $0.350^{* * *}$ & $0.387^{* * *}$ & $0.386^{* * *}$ & $0.443^{* * *}$ \\
\hline & $(0.067)$ & $(0.068)$ & $(0.066)$ & $(0.065)$ & $(0.067)$ & $(0.068)$ & $(0.066)$ & $(0.065)$ \\
\hline FD & $\begin{array}{l}-0.007 \\
(0.005)\end{array}$ & $\begin{array}{l}-0.007 \\
(0.003)\end{array}$ & $\begin{array}{l}-0.004 \\
(0.005)\end{array}$ & $\begin{array}{l}-0.003 \\
(0.001)\end{array}$ & $\begin{array}{l}-0.003 \\
(0.005)\end{array}$ & $\begin{array}{l}-0.003 \\
(0.004)\end{array}$ & $\begin{array}{l}-0.001 \\
(0.005)\end{array}$ & $\begin{array}{l}-0.002 \\
(0.001)\end{array}$ \\
\hline $\begin{array}{l}\text { Inflation volatility*I(FD in } \\
\text { the lower regime) }\end{array}$ & 0.037 & 0.021 & 0.049 & $0.044^{* *}$ & 1.328 & 0.270 & $4.488^{* * *}$ & $6.098^{* * *}$ \\
\hline & $(0.027)$ & $(0.024)$ & $(0.031)$ & $(0.022)$ & $(2.713)$ & $(1.091)$ & (2.208) & $(1.688)$ \\
\hline $\begin{array}{l}\text { Inflation volatility*I(FD in } \\
\text { the higher regime) }\end{array}$ & 0.511 & 0.367 & $0.557^{*}$ & 0.602 & $1.279^{*}$ & 1.260 & 0.972 & 0.720 \\
\hline & $(0.311)$ & $(0.223)$ & $(0.304)$ & $(0.711)$ & $(0.664)$ & $(0.885)$ & $(0.634)$ & $(0.670)$ \\
\hline Economy size & 0.001 & -0.002 & 0.0001 & -0.0004 & 0.003 & -0.001 & 0.003 & 0.003 \\
\hline & $(0.004)$ & $(0.004)$ & $(0.004)$ & $(0.004)$ & $(0.004)$ & $(0.004)$ & $(0.004)$ & $(0.005)$ \\
\hline Trade openness & $0.013^{* * *}$ & $0.013^{* * *}$ & $0.011^{* * *}$ & $0.011^{* * *}$ & $0.012^{* * *}$ & $0.013^{* * *}$ & $0.011^{* * *}$ & $0.009^{* *}$ \\
\hline & $(0.004)$ & $(0.004)$ & $(0.004)$ & $(0.004)$ & $(0.004)$ & $(0.004)$ & $(0.004)$ & $(0.004)$ \\
\hline Government size & $\begin{array}{c}0.019 \\
(0.045)\end{array}$ & $\begin{array}{c}0.019 \\
(0.046)\end{array}$ & $\begin{array}{c}0.038 \\
(0.044)\end{array}$ & $\begin{array}{c}0.033 \\
(0.046)\end{array}$ & $\begin{array}{l}-0.009 \\
(0.050)\end{array}$ & $\begin{array}{c}0.002 \\
(0.051)\end{array}$ & $\begin{array}{c}0.019 \\
(0.050)\end{array}$ & $\begin{array}{c}0.021 \\
(0.051)\end{array}$ \\
\hline Recession dummy & 0.004 & 0.004 & 0.003 & 0.002 & $0.005^{*}$ & 0.004 & 0.004 & 0.003 \\
\hline Constant & $\begin{array}{l}(0.003) \\
0.015^{* * *} \\
(0.005)\end{array}$ & $\begin{array}{l}(0.003) \\
0.014^{* * *} \\
(0.004)\end{array}$ & $\begin{array}{c}(0.003) \\
0.009 \\
(0.006)\end{array}$ & $\begin{array}{l}(0.003) \\
-0.002 \\
(0.003)\end{array}$ & $\begin{array}{c}(0.003) \\
0.014 \\
(0.013)\end{array}$ & $\begin{array}{c}(0.003) \\
0.016 \\
(0.010)\end{array}$ & $\begin{array}{c}(0.003) \\
-0.007 \\
(0.010)\end{array}$ & $\begin{array}{c}(0.003) \\
-0.026^{* * *} \\
(0.008) \\
\end{array}$ \\
\hline Threshold point & 0.193 & 0.601 & 0.167 & -0.023 & 0.192 & 0.601 & 0.229 & -1.115 \\
\hline Confidence interval & $0.184-0.216$ & $0.600-1.378$ & $0.122-0.710$ & $-1.116-0.703$ & $0.165-0.211$ & $0.600-1.260$ & $0.116-0.234$ & $-1.375--0.569$ \\
\hline Observations & 828 & 828 & 828 & 828 & 828 & 828 & 828 & 828 \\
\hline
\end{tabular}

Note: ${ }^{* * *},{ }^{* *}$ and ${ }^{*}$ show the significance at the level of $1 \%, 5 \%$ and $10 \%$, respectively. Standard error is provided in parentheses. The results are obtained by Eq. (3.2). 


\subsection{Conclusions}

In this paper, I investigate the growth volatility in the 50 countries from 1997 to 2014 and find that the aggregate growth volatility in the global has a declining trend but soars in the South American Economic Crisis (2002-2003), the Global Financial Crisis (2008-2009) and the European Debt Crisis (2010-2012). The advanced countries have the smaller growth volatility than emerging countries. By applying the dynamic panel threshold model to investigate the nonlinear effect of financial sector development on the growth volatility, it is evident that growth volatility has a significant and positive first lagged autocorrelation pattern. Financial sector development could reduce growth volatility by using banking credit and health indicators in the lower regime. Regarding the shock of inflation volatility, I confirm that financial sector development can magnify its effect on the growth volatility in the higher regime, especially in the advanced countries. Furthermore, I find that economy size and trade openness have significant positive influences on the growth volatility.

In the robustness tests, it is evident that financial openness, human capital investment, law and institution quality significantly reduce growth volatility. I also obtain very similar results by using the alternative inflation volatility variable (PPI volatility). To handle the endogeneity in the models, I apply the first lagged inflation volatility and the central bank assets to GDP as instrument variables to replace inflation 
volatility, respectively. The results demonstrate that my results are very robust, that is, inflation volatility positively affects the growth volatility and excessive financial sector development magnifies the shock of inflation volatility on the growth volatility. My results reveal the importance of governments and regulation institutions keeping financial sector development in a single optimal level. This is helpful in reducing aggregate fluctuations and dampening the inflation shocks. 


\section{CHAPTER 4}

\section{REVISTING BANK CREDIT AND THE BUSINESS CYCLE}

\subsection{Introduction}

Some classical papers investigate the sources of economic cyclical fluctuations and focus on the roles of financial factors on the business cycle. In the early age, Schumpeter (1934) and Gurley and Shaw (1955) emphasize the close relationship between the financial cycle and the business cycle. Bernanke et al. (1996) find that financial factors can amplify business cycle fluctuations. When investment projects become more risky or difficult to evaluate, credit supply falls and business cycle movements emerge. Kiyotaki and Moore (1997) emphasize the roles played by movements of credit and asset price in shaping macroeconomic aggregate changes over the business cycle. They think that the changes of external financing supply can affect corporations and households, and thereby influence aggregate business cycles.

Recently, Dell' Ariccia et al. (2008) observe that a long financial sector cycle is coupled with a greater synchronization with the real economy. Nolan and Thoenissen (2009) and Mandelman (2010) find the shocks from the financial sector play an important role as a source of business cycle fluctuations. Jordà et al. (2013) argue that financial factors play an essential role in the cyclical fluctuations in the fourteen developed 
economies from 1870 to 2008. Caldara et al. (2016) also observe that financial shocks become an important source of cyclical fluctuations since the mid-1980. Ma and Zhang (2016) suggest the financial cycle shock becomes a main driving force for macroeconomic fluctuations, especially during the financial instability period.

Furthermore, the business cycle is thought as asymmetric and non-identical mirror-image (Mitchell, 1927; Keynes, 1936; Sichel, 1993; Ramsey and Rothman, 1996). It is thought that output cycles tend to have the asymmetric longer expansionary and shorter contractionary phases (Egert and Sutherland, 2014) and the effects of the credit cycle are asymmetric in the business expansions and contractions (Bartoletto et al., 2015). Therefore, I believe the linear models are not a good fit with the asymmetric patterns of the business cycle.

In order to make up for the deficiency of the linear models, I employ quantile regression to investigate the asymmetric effects of bank credit on the business cycle. The change of the business cycle after the financial crisis is tested because of the implementation of Basil II (see Lowe and Segoviano, 2002; Kashyap and Stein, 2004; Pederzoli and Torricelli, 2005). The roles of the other financial factors on the business cycle are also explored, including M2 supply and stock price. The empirical results show that bank credit is pro-cyclical and amplifies the business cycle. This effect is larger in the economic peak and trough, which forms a U-shape curve. The influences of M2 supply 
and stock price on the business cycle also show the U-shaped. Bank credit supply behavior constrains after financial crisis and then negatively affects the business cycle.

The asymmetry of the business cycle is explored by a large number of papers. Mitchell (1927) and Keynes (1936) observe that business contractions are more sudden, violent and briefer than business expansions, and business contractions. Sichel (1993) and Ramsey and Rothman (1996) find that a real output series has depth if its troughs are deeper than its expansions, and has steepness if its downturns are steeper than its expansions. It is widely thought that the distribution of GDP, business fluctuations and other macroeconomic aggregates are asymmetric. For example, Bodman (2001) explores the asymmetries in the Australian macroeconomic time series and finds the evidence of steepness. Narayan and Narayan (2008) explore the asymmetries in the macroeconomic time series in the three Asian economies and conclude that most of the series are characterized by asymmetric behaviors. Narayan (2009) also examines the asymmetric behavior of per capita GDP in the eleven OECD countries and documents that per capita GDP displays a substantial asymmetric behavior.

Regarding the roles of bank credit on the business cycle, Halvorsen and Jacobsen (2014) think that the bank plays a vital role in the financial system since the bank specializes in overcoming informational problems and is a predominant source of credit supply. Many papers document that bank credit is pro-cyclical and amplifies the business cycle. Asea and Blomberg (1998) document that bank lending drives and amplifies the 
overall real business cycle in the United States. Using 44 countries over 50 years, Claessens et al. (2012) show that the rapid credit growth tends to amplify the economic expansions. Apostoaie et al. (2014) confirm a strong relationship of a pro-cyclical nature between the credit cycle and the business cycle in the 12 European countries. Egert and Sutherland (2014) provide the new evidence on the banking sector's pro-cyclicality by using the aggregate and bank-level data in the OECD countries. Halvorsen and Jacobsen (2014) observe that an adverse bank lending shock contracts output in Norway and UK by applying the structural VARs from 1988 to 2010. They suggest that the financial sector is an important source of economic shocks. Ibrahim (2016) finds that the aggregate bank credit is pro-cyclical, regarding 21 conventional banks and 16 Islamic banks from 2001 to 2013. The pro-cyclicality of bank credit on the business cycle is supported by Bertay et al. (2015) by using the data of 633 banks in the 111 countries from 1999 to 2010. Mimir (2016) also shows that bank credit is pro-cyclical and explores the joint roles of financial shocks and credit frictions in driving the real and financial fluctuations.

It is well known that various actions were taken by governments around the world to address the effects of the subprime mortgage crisis. One of the most important measures was to increase the regulation on the banking system, such as the implementation of Basel II. Although limited, there is also some evidence of pro-cyclical effects arising from the application of Basel II (Lowe and Segoviano, 2002; Kashyap and Stein, 2004). Pederzoli and Torricelli (2005) argue that the main object of minimum capital requirements in Basel 
II is to make the capital requirements more risk-sensitive. The increased risk-sensitivity of capital requirements raises the concerns about a possible pro-cyclicality side-effect due to the dependence of credit risk on the business cycle.

Regarding other economic determinants of the business cycle, Kose et al. (2003), Bejan (2006), Bekaert et al. (2006), Giovanni and Levchenko (2009) and Claessens et al. (2012) find that business cycle fluctuations are related with trade openness though the pro-cyclical or counter-cyclical characteristics of trade openness are uncertain. Lane (2003), Gali and Perotti (2003), Alesina et al. (2008) and Magud (2008) mention that business cycle fluctuations are attributed to the impacts of fiscal policy whereas fiscal policy may be expansionary or contractionary in terms of output. Furthermore, Kilian and Vigfusson (2011a, b) investigate the asymmetric responses of GDP on the oil price shocks. Mohaddes and Pesaran $(2016,2017)$ suggest that the effects of oil shocks are widespread in the global economy. Kose and Yi (2006), Faia (2007), Kose, et al. (2008) and Claessens et al. (2012) confirm the significant inter-correlations of the business cycles among the countries. Furthermore, Baxter and Stockman (1989) find that the business cycle is largely influenced by the variability of the real exchange rate under the fixed and flexible exchange rate systems. Duarte et al. (2007) document the empirical evidence on the business cycle relationship between exchange rates and macroeconomic aggregates in 36 countries. 
However, I find that most theoretical and empirical models in macroeconomics apply the linear adjustment mechanisms, which implies that the responses of economic variables to shocks are symmetric. However, the business cycle is thought of as asymmetric and non-identical mirror-image (Mitchell, 1927; Keynes, 1936; Sichel, 1993; Ramsey and Rothman, 1996). Bodman (2001) finds that the types of shocks to affect business cycles might be different or the propagation mechanism might be different over the business cycle. Kiani and Bidarkota (2004) explain that the nonlinearities can seriously influence the persistence of monetary policies and affect other shocks on the output based on the linear models. Therefore, I believe that the linear models are not sufficient to deal with the business cycle with asymmetrical behavior.

In the case of the asymmetric relationship with bank credit and the business cycle, Bikker and Metzemakers (2005) confirm that credit risk of bank is closely linked to the phases of the business cycle. Adrian and Shin (2010) attribute that bank leverage is high during economic booms and low during busts so that the banks tend to provide more credits to the business during economic booms and cut the new credits during busts. Bartoletto et al. (2015) carry out some statistical tests on the co-movement between the credit and the business cycle in Italy and show that the co-movement proves weaker in recessions. Furthermore, Garcia and Schaller (2002) use a measurement for monetary policy shocks and find monetary policy has the larger effects during a recession than during an expansion. Lo and Piger (2005) account for the different forms of asymmetry in 
the monetary transmission mechanism and confirm the asymmetric transmission of monetary policy over contractions and expansions in the business cycle. They find that monetary policy innovations have greater impacts on output during contractions. Santoro et al. (2014) also show that monetary policy has stronger effects on the GDP during contractions, compared with expansions. Considering the asymmetric relationship of bank credit and the business cycle, I apply an approach of quantile regression to investigate their relationship in this paper.

\subsection{Methodology}

\subsubsection{Regression model}

I apply the quantile regression (Koenker and Bassett, 1978) and the quantile regression for panel data (QRPD) (Powell, 2016a) to explore the asymmetric relationship of bank credit with the business cycle. The QRPD estimator is thought as the first quantile panel data estimator to provide the estimation which can be interpreted in the same manner as the cross-sectional regression results while the fixed effects are allowed to be arbitrarily correlated with the variables of interest. Besides, the interpretation of QRPD parallels the interpretation of the bounds by using the Chernozhukov et al. (2013) framework. Chernozhukov et al. (2013) discuss the identification of bounds on quantile effects in nonseparable panel models with exogenous variables and show that these bounds tighten as $\mathrm{T}$ increases. 
A further advantage of the QRPD refers that the moment conditions are simple to interpret and implement since the individual fixed effects are never estimated or even specified. Therefore, the number of estimated parameters is smaller and the implementation of this estimator is simpler, compared with other most quantile panel data estimators (e.g. Koenker, 2004; Lamarche, 2010; Galvao, 2011; Kato et al., 2012 and Rosen, 2012). The properties of the moment conditions are also helpful to further reduce the number of estimated parameters independently.

In order to investigate the effects of bank credit on the business cycle in the different phases, I apply the quantile regression for panel data (QRPD) (Powell, 2016a) to estimate the following model, which is shown as:

$$
G D P_{i t}=\beta_{1} \operatorname{CREDIT}_{i t-1}+\beta_{2} \operatorname{POST}_{t}+\beta_{3} G O V_{i t-1}+\beta_{4} T R A D E_{i t-1}+\beta_{5} O L_{t-1}+\varepsilon_{i t}
$$

where GDP is the business cycle measured by log GDP. CREDIT is bank credit measured by $\log$ credit, which is the variable of interest in this paper. POST is the dummy variable to distinguish the periods before or after the global financial crisis $(P O S T=1$ from the global financial crisis in 2008). The control variables include government expenditure (GOV), trade openness (TRADE) and oil price (OIL). $\varepsilon_{i t}$ is the error term. $i$ and $t$ denote the country and time, respectively. In line with Powell (2016b), the more control variables can predict the placement in the distribution relative to the quantile function ${ }^{25}$. I also use

${ }^{25}$ I use the qregpd package in STATA to fit the quantile regression for panel data (QRPD) estimator developed in Powell (2016a). 
additional control variables in the robustness tests, including world output (OUTPUT) and foreign exchange rate $(F X)$. Meanwhile, I apply the alternative financial factors in this paper, including M2 supply (M2) and stock market price (STOCK). All the variables are detrended by the Hodrick-Prescott filter to get the cyclicality and the smoothing parameter is set as $1600^{26}$. The detailed description could be found in Table 4.1.

\subsubsection{Data}

In this paper, I collect the data of 42 countries and select 18 countries for my investigation because I do not find the significant positive relationships of bank credit and the business cycle in the other 24 countries by using the quantile regression (Koenker and Bassett, 1978). I collect the real GDP, import, export and world output data from the Global Economic Monitor (GEM) and collect bank credit and real effective exchange rate from the Bank of International Settlements Statistics. I also obtain the world price of oil from the International Financial Statistics in IMF and collect M2 supply and MSCI stock price index from the Datastream. The data I use in this paper are quarterly from 1999 to 2016.

Table 4.2 shows the results of the descriptive statistics and the normality tests on the business cycle in each sample country. I observe that Russia (0.025) has the largest volatility followed by Greece (0.024) and Hong Kong (0.022). However, the volatility in

\footnotetext{
${ }^{26}$ In this paper, I explore the level asymmetry (deepness) of the business cycle, which refers to the unconditional distribution of detrended output levels. It is different from the growth rate asymmetry, which refers to the unconditional distribution of output changes.
} 
Australia (0.005), Indonesia (0.005) and New Zealand (0.010) is smaller. Greece (-0.028) and Russia (-0.026) have a larger downside amplitude (10\% quantile) but Australia (-0.008) and Indonesia (-0.007) have a larger downside amplitude (10\% quantile). Besides, it is evident that Greece (0.033) has the largest upside amplitude (90\% quantile), followed by Hong Kong (0.029) and Russia (0.023). Australia (0.008) and Indonesia (0.005) have a smaller upside amplitude (90\% quantile). Regarding the descriptive statistics in the pool data of the advanced and emerging countries, I observe that the advanced countries have a smaller volatility, downside amplitude and upside amplitude than the emerging countries, whose findings are consistent to Kose et al. (2003) and Calderón and Fuentes (2014). They argue that emerging countries experience the greater macroeconomic volatility.

In order to test the normality of the business cycle for each country, I apply the Skewness test, the Kurtosis test, the Normal test and the Shapiro-Wilk test. I observe that most countries have negative skewness, except New Zealand, United Kingdom, Colombia and Russia. Negative skewness in the distribution of detrended output levels shows the presence of slow increases and sudden decreases of output. The results of the Kurtosis test show that the most values are significant and positive. These results show that the business cycles in the most countries are asymmetric and fat-tailed. 
Table 4.1 Variables and their meanings

\begin{tabular}{ccc}
\hline Type & Variables & Meanings \\
\hline Economic movement & Business cycle & GDP at market prices, constant 2010 USD \\
\hline \multirow{2}{*}{ Financial factors } & Bank credit & Credit for non financial sector (Market value in USD) \\
& M2 supply & Money supply M2, standardized USD, 2010 prices \\
Post financial crisis & Time dummy variable & The dummy variable equals to 1 from 2008 \\
\hline \multirow{2}{*}{ Control variables } & Government & Government consumption, standardized USD, 2010 \\
& expenditure & prices \\
& Foreign exchange rate & BIS effective exchange rate, real (CPI-based), \\
& Trade openness & 2010=100 \\
& Oil price & (Export plus import)/GDP, constant 2010 USD, \\
& World output & Total GDP of OECD (high income) and China, constant \\
& & 2010 USD
\end{tabular}

Note: Oil price is a simple average of three spot prices, that is, Dated Brent, West Texas Intermediate, and the Dubai Fateh. All the variables are detrended by using the Hodrick-Prescott filter and the smoothing parameter is set as 1600 .

In the results of the Normal test and the Shapiro-Wilk test, I further find that the business cycles of some advanced countries are significantly asymmetric and fat-tailed because the P-values are much less than 0.05, including Canada, Israel, South Korea and United Kingdom. The business cycles of the emerging countries are also significantly asymmetric and fat-tailed, including Chile, Indonesia, Malaysia, Mexico, Russia and Thailand. The pool data for the business cycles of the advanced and emerging countries obviously are both asymmetric and fat-tailed. It shows the necessity to apply the quantile regression to investigate the business cycle for the sample countries. 
Table 4.2 The basic features of the business cycle

\begin{tabular}{|c|c|c|c|c|c|c|c|c|}
\hline & Volatility & $10 \%$ quantile & $50 \%$ quantile & $90 \%$ quantile & Skewness test & Kurtosis test & Normal test & Shapiro-Wilk test \\
\hline \multicolumn{9}{|c|}{ Advanced countries } \\
\hline Australia & 0.005 & -0.008 & 0.0003 & 0.008 & -0.011 & -0.242 & 0.953 & 0.873 \\
\hline Canada & 0.011 & -0.014 & 0.0003 & 0.013 & $-0.917^{* * *}$ & $1.277^{*}$ & 0.005 & 0.005 \\
\hline Greece & 0.024 & -0.028 & 0.0003 & 0.033 & -0.127 & -0.326 & 0.784 & 0.118 \\
\hline Hong Kong & 0.022 & -0.025 & 0.0007 & 0.029 & -0.417 & $1.184^{*}$ & 0.072 & 0.117 \\
\hline Israel & 0.017 & -0.017 & -0.0021 & 0.022 & $0.707^{* *}$ & $2.329^{* * *}$ & 0.005 & 0.006 \\
\hline New Zealand & 0.010 & -0.010 & -0.0007 & 0.011 & 0.148 & 0.958 & 0.243 & 0.124 \\
\hline South Korea & 0.012 & -0.013 & 0.0004 & 0.014 & $-1.055^{* * *}$ & $2.729^{* * *}$ & 0.000 & 0.000 \\
\hline United Kingdom & 0.012 & -0.011 & -0.0007 & 0.012 & 0.358 & $1.830^{* *}$ & 0.038 & 0.000 \\
\hline United States & 0.011 & -0.016 & 0.0004 & 0.015 & -0.301 & 0.018 & 0.527 & 0.559 \\
\hline Pool data & 0.015 & -0.016 & -0.0001 & 0.017 & $-0.174^{*}$ & $2.725^{* * *}$ & 0.000 & 0.000 \\
\hline \multicolumn{9}{|c|}{ Emerging countries } \\
\hline Brazil & 0.017 & -0.022 & 0.0027 & 0.021 & -0.438 & 0.001 & 0.276 & 0.320 \\
\hline Chile & 0.016 & -0.021 & 0.0012 & 0.017 & $-0.610^{* *}$ & 0.290 & 0.085 & 0.066 \\
\hline Colombia & 0.013 & -0.017 & -0.0013 & 0.016 & 0.365 & -0.345 & 0.369 & 0.286 \\
\hline India & 0.014 & -0.017 & -0.0009 & 0.015 & -0.289 & 1.036 & 0.139 & 0.379 \\
\hline Indonesia & 0.005 & -0.007 & -0.0001 & 0.005 & $0.839^{* * *}$ & $1.603^{* *}$ & 0.005 & 0.007 \\
\hline Malaysia & 0.016 & -0.010 & 0.0010 & 0.015 & $-0.681^{* *}$ & $4.390^{* * *}$ & 0.003 & 0.000 \\
\hline Mexico & 0.017 & -0.018 & -0.0007 & 0.023 & $-0.559^{* *}$ & $1.153^{*}$ & 0.041 & 0.010 \\
\hline Russia & 0.025 & -0.026 & -0.0066 & 0.023 & $0.667^{* *}$ & $1.713^{* *}$ & 0.012 & 0.003 \\
\hline Thailand & 0.018 & -0.019 & 0.0024 & 0.017 & $-1.787^{* * * *}$ & $5.515^{* * *}$ & 0.000 & 0.000 \\
\hline Pool data & 0.017 & -0.018 & -0.0001 & 0.018 & $-0.219^{* *}$ & $3.219^{* * *}$ & 0.000 & 0.000 \\
\hline
\end{tabular}

Note: I use the standard deviation of detrended GDP to measure the volatility of the business cycle for each sample country. The values in the columns of the Normal test and the Shapiro-Wilk test are P-values. 
Table 4.3 The correlations of the variables

\begin{tabular}{|c|c|c|c|c|c|c|c|c|}
\hline & Business cycle & Bank credit & M2 supply & Stock price & $\begin{array}{l}\text { Post financial } \\
\text { crisis }\end{array}$ & $\begin{array}{c}\text { Fiscal } \\
\text { expenditure }\end{array}$ & $\begin{array}{c}\text { Trade } \\
\text { openness }\end{array}$ & Oil price \\
\hline Business cycle & 1.000 & & & & & & & \\
\hline Bank credit & $0.441^{* * *}$ & 1.000 & & & & & & \\
\hline M2 supply & $0.473^{* * * *}$ & $0.748^{* * * *}$ & 1.000 & & & & & \\
\hline Stock price & $0.500^{* * *}$ & $0.624^{* * *}$ & $0.601^{* * *}$ & 1.000 & & & & \\
\hline Post financial crisis & $-0.046^{*}$ & -0.016 & -0.007 & $-0.067^{* *}$ & 1.000 & & & \\
\hline Fiscal expenditure & $0.131^{* * *}$ & $0.131^{* * *}$ & $0.195^{* * * *}$ & $0.078^{* * *}$ & 0.034 & 1.000 & & \\
\hline Trade openness & $0.237^{* * *}$ & $0.121^{* * *}$ & $0.066^{* *}$ & $0.181^{* *}$ & 0.034 & -0.025 & 1.000 & \\
\hline Oil price & $0.427^{* * *}$ & $0.430^{* * *}$ & $0.377^{* * * *}$ & $0.539^{* * *}$ & -0.021 & 0.030 & $0.234^{* * *}$ & 1.000 \\
\hline
\end{tabular}


Table 4.3 shows the correlations of the variables in this paper. In particular, bank credit, M2 supply and stock price have the significant positive relationships with the business cycle. The correlation coefficients of the business cycle with bank credit, M2 supply and stock price are $0.159,0.126$ and 0.541 , respectively. The dummy variable of the post financial crisis is negatively correlated with the business cycle since Basel II is taken to increases the requirement of bank capital, increase risk-sensitiveness and then decreases the capacity of bank to supply credit. Moreover, fiscal expenditure, trade openness and oil price have positive impacts on the business cycle.

\subsection{Empirical Results}

Regarding the asymmetric and fat-tailed features of the business cycle, I use the OLS and the quantile estimation method (Koenker and Bassett, 1978) to investigate the asymmetric effects of bank credit on the business cycle for each sample country. Table 4.4 shows that the most countries have significant positive effects of bank credit on the business cycle. In the results of the OLS estimation, it is evident that United States (0.235), Chile (0.221) and India (0.196) have larger significant positive effects of bank credit on the business cycle but the positive effects on the business cycle are smaller in Australia (0.031), New Zealand (0.051) and Indonesia (0.042).

In the results of the quantile regression, I observe that the effects of bank credit on the business cycle are significant and positive in most countries and in most of the quantiles. 
In particular, I observe that the effects of bank credit on the business cycle are larger below $30 \%$ quantiles and above $70 \%$ quantiles, which show a U-shaped curve. In economic recessions, the explanatory monetary polices tend to be applied and bank lending plays an important role in the amplification of monetary policy shocks on real variables (see Bernanke and Gertler, 1995). In the economic booms, the bank tends to increase credit supply. Furthermore, large heterogeneity exists among the sample countries. Specifically, bank credit has significant and positive effects on the business cycle only in the low quantiles in Hong Kong and Malaysia, where the explanatory monetary policy shows very effective to help the economic recovery. However, Colombia and the United States have significant and positive relationships of bank credit and the business cycle in the higher quantiles. In the case of Brazil and Chile, the effects of bank credit are larger in the lower quantiles and decrease with the increase of quantile points.

Alternatively, the effects of bank credit on the business cycle increase with the increase of quantile points in Thailand. The effects of bank credit on the business cycle are larger in the middle quantiles in Indonesia. These results present the effects of bank credit on the business cycle change in the different business cycle phases for the different countries. My findings demonstrate that bank credit shows pro-cyclical and amplifies the business cycle but its roles on the business cycle are asymmetric (Bikker and Metzemakers, 2005; Adrian and Shin, 2010; Bartoletto et al., 2015). The asymmetric 
effects might be caused by the expansionary or contractionary monetary policy (Garcia and Schaller, 2002; Lo and Piger, 2005; Santoro et al., 2014).

In order to investigate the overall effect of bank credit on the business cycle for all the sample countries, I apply the panel quantile regression (PQRD) (Powell, 2016a) in this section. In the results of the FGLS estimation, Table 4.5 shows that bank credit has a positive impact on the business cycle. It means that bank credit is pro-cyclical and amplifies the business cycle. The dummy variable of the post financial crisis negatively affects the business cycle since the requirement of capital, liquidity management and supervision improve after global financial crisis, which constrains the bank capacity to allocate credit to the firms. Regarding the control variables, the coefficient of fiscal expenditure is significant positive, which means that the business cycle is positively correlated with fiscal policy. Furthermore, I observe that trade openness and oil price have significant and positive effects on the business cycle, which shows that external economic shocks aggravate the business cycle. 
Table 4.4 The results of the quantile regression for each sample country

\begin{tabular}{|c|c|c|c|c|c|c|c|c|c|c|}
\hline & OLS & $10 \%$ & $20 \%$ & $30 \%$ & $40 \%$ & $50 \%$ & $60 \%$ & $70 \%$ & $80 \%$ & $90 \%$ \\
\hline \multicolumn{11}{|c|}{ Advanced countries } \\
\hline \multirow[t]{2}{*}{ Australia } & $0.031^{* * *}$ & $0.044^{* *}$ & $0.032^{* * *}$ & $0.033^{* * *}$ & $0.033^{* *}$ & $0.022^{*}$ & $0.028^{* * *}$ & $0.028^{* * *}$ & $0.035^{* * *}$ & $0.031^{* * *}$ \\
\hline & $(0.007)$ & $(0.021)$ & $(0.010)$ & $(0.010)$ & $(0.013)$ & $(0.013)$ & $(0.010)$ & $(0.009)$ & $(0.009)$ & $(0.011)$ \\
\hline \multirow[t]{2}{*}{ Canada } & $0.109^{* * *}$ & $0.130^{* *}$ & $0.118^{* *}$ & $0.115^{* *}$ & $0.107^{*}$ & $0.078^{*}$ & $0.085^{* * *}$ & $0.089^{* * *}$ & $0.094^{* * *}$ & $0.129^{* * *}$ \\
\hline & $(0.023)$ & $(0.055)$ & $(0.056)$ & $(0.053)$ & $(0.055)$ & $(0.044)$ & $(0.025)$ & $(0.015)$ & $(0.016)$ & $(0.035)$ \\
\hline \multirow[t]{2}{*}{ Greece } & $0.134^{* * *}$ & $0.135^{* * *}$ & $0.129^{*}$ & $0.104^{*}$ & $0.104^{*}$ & 0.044 & 0.079 & $0.147^{* * *}$ & $0.179^{* * *}$ & $0.139^{* * *}$ \\
\hline & $(0.035)$ & $(0.047)$ & $(0.066)$ & $(0.063)$ & $(0.061)$ & $(0.070)$ & $(0.069)$ & $(0.050)$ & $(0.032)$ & $(0.026)$ \\
\hline \multirow[t]{2}{*}{ Hong Kong } & $0.238^{* *}$ & $0.275^{*}$ & $0.327^{* * * *}$ & $0.205^{* *}$ & $0.167^{* *}$ & 0.135 & 0.095 & 0.085 & -0.016 & 0.055 \\
\hline & $(0.100)$ & $(0.142)$ & $(0.077)$ & $(0.085)$ & $(0.083)$ & $(0.085)$ & $(0.099)$ & $(0.168)$ & $(0.240)$ & $(0.222)$ \\
\hline \multirow[t]{2}{*}{ Israel } & $0.108^{* * *}$ & 0.066 & $0.105^{* *}$ & $0.097^{* *}$ & $0.086^{* *}$ & $0.108^{* * *}$ & $0.095^{* * *}$ & $0.112^{* *}$ & 0.096 & $0.305^{* *}$ \\
\hline & $(0.039)$ & $(0.059)$ & $(0.051)$ & $(0.046)$ & $(0.037)$ & $(0.039)$ & $(0.035)$ & $(0.053)$ & $(0.104)$ & $(0.140)$ \\
\hline \multirow[t]{2}{*}{ New Zealand } & $0.051^{* * *}$ & $0.041^{* *}$ & $0.026^{* *}$ & $0.040^{* * *}$ & $0.040^{* * *}$ & $0.046^{* * *}$ & $0.053^{* *}$ & $0.050^{*}$ & $0.063^{* *}$ & $0.078^{* * *}$ \\
\hline & $(0.012)$ & $(0.019)$ & $(0.013)$ & $(0.013)$ & $(0.014)$ & $(0.017)$ & $(0.022)$ & $(0.029)$ & $(0.029)$ & $(0.022)$ \\
\hline \multirow[t]{2}{*}{ South Korea } & $0.088^{* * *}$ & $0.120^{* * *}$ & $0.116^{* * *}$ & $0.082^{* *}$ & $0.076^{* *}$ & $0.064^{*}$ & $0.087^{* * *}$ & $0.072^{* * *}$ & $0.092^{* * *}$ & $0.067^{*}$ \\
\hline & $(0.019)$ & $(0.042)$ & $(0.034)$ & $(0.041)$ & $(0.039)$ & $(0.033)$ & $(0.029)$ & $(0.024)$ & $(0.028)$ & $(0.035)$ \\
\hline \multirow[t]{2}{*}{ United Kingdom } & $0.134^{* * *}$ & $0.117^{* *}$ & $0.142^{* * *}$ & $0.110^{* *}$ & $0.091^{* * *}$ & $0.097^{* * *}$ & $0.095^{* * *}$ & $0.123^{* * *}$ & $0.141^{* * *}$ & $0.183^{* * *}$ \\
\hline & $(0.020)$ & $(0.051)$ & $(0.051)$ & $(0.043)$ & $(0.034)$ & $(0.031)$ & $(0.033)$ & $(0.039)$ & $(0.047)$ & $(0.034)$ \\
\hline \multirow[t]{2}{*}{ United States } & $0.235^{* *}$ & -0.202 & 0.237 & 0.232 & $0.333^{* *}$ & $0.466^{* * *}$ & $0.500^{* * *}$ & $0.422^{* * *}$ & $0.540^{* * *}$ & $0.654^{* * *}$ \\
\hline & $(0.112)$ & $(0.260)$ & $(0.213)$ & $(0.149)$ & $(0.163)$ & $(0.157)$ & $(0.128)$ & $(0.126)$ & $(0.130)$ & $(0.108)$ \\
\hline \multirow[t]{2}{*}{ Pool data } & $0.086^{* * *}$ & $0.116^{* * *}$ & $0.076^{* * *}$ & $0.067^{* * *}$ & $0.060^{* * *}$ & $0.057^{* * *}$ & $0.059^{* * *}$ & $0.069^{* * *}$ & $0.075^{* * *}$ & $0.099^{* * *}$ \\
\hline & $(0.009)$ & $(0.020)$ & $(0.016)$ & $(0.011)$ & $(0.009)$ & $(0.006)$ & $(0.010)$ & $(0.010)$ & $(0.013)$ & $(0.020)$ \\
\hline \multicolumn{11}{|c|}{ Emerging countries } \\
\hline \multirow[t]{2}{*}{ Brazil } & $0.097^{* * *}$ & $0.129^{\text {**** }}$ & $0.120^{* * *}$ & $0.127^{* * *}$ & $0.120^{* * *}$ & $0.124^{* * *}$ & $0.096^{* * *}$ & $0.093^{* * *}$ & $0.079^{* * *}$ & 0.058 \\
\hline & $(0.017)$ & $(0.032)$ & $(0.031)$ & $(0.030)$ & $(0.029)$ & $(0.028)$ & $(0.031)$ & $(0.030)$ & $(0.030)$ & $(0.036)$ \\
\hline Chile & $0.221^{* * *}$ & $0.278^{* * *}$ & $0.226^{* * *}$ & $0.238^{* * *}$ & $0.218^{* * *}$ & $0.210^{* * *}$ & $0.173^{* * *}$ & $0.162^{* * *}$ & $0.163^{* * *}$ & $0.228^{* * *}$ \\
\hline
\end{tabular}




\begin{tabular}{lcccccccccc} 
& $(0.033)$ & $(0.069)$ & $(0.041)$ & $(0.030)$ & $(0.033)$ & $(0.039)$ & $(0.045)$ & $(0.046)$ & $(0.052)$ & $(0.071)$ \\
Colombia & $0.082^{* *}$ & 0.078 & $0.062^{*}$ & 0.051 & $0.073^{* *}$ & $0.082^{* * *}$ & $0.074^{* * *}$ & $0.086^{* * *}$ & $0.090^{* * *}$ & $0.091^{* * * *}$ \\
& $(0.033)$ & $(0.054)$ & $(0.032)$ & $(0.036)$ & $(0.034)$ & $(0.030)$ & $(0.026)$ & $(0.026)$ & $(0.024)$ & $(0.033)$ \\
India & $0.196^{* * *}$ & $0.265^{* * *}$ & $0.215^{* *}$ & $0.177^{* *}$ & $0.145^{* *}$ & $0.156^{* * *}$ & $0.189^{* * *}$ & $0.187^{* * *}$ & $0.200^{* * *}$ & $0.202^{* * *}$ \\
& $(0.032)$ & $(0.097)$ & $(0.087)$ & $(0.072)$ & $(0.061)$ & $(0.049)$ & $(0.041)$ & $(0.036)$ & $(0.045)$ & $(0.045)$ \\
Indonesia & $0.042^{* * *}$ & 0.004 & 0.032 & $0.052^{* * *}$ & $0.053^{* * *}$ & $0.048^{* * *}$ & $0.050^{* * * *}$ & $0.044^{* * *}$ & $0.031^{*}$ & 0.041 \\
& $(0.012)$ & $(0.031)$ & $(0.022)$ & $(0.017)$ & $(0.012)$ & $(0.011)$ & $(0.011)$ & $(0.013)$ & $(0.017)$ & $(0.037)$ \\
Malaysia & $0.146^{* * *}$ & $0.258^{* *}$ & $0.161^{* *}$ & $0.127^{*}$ & $0.105^{* *}$ & $0.084^{*}$ & 0.060 & 0.063 & 0.035 & 0.117 \\
& $(0.051)$ & $(0.113)$ & $(0.081)$ & $(0.065)$ & $(0.052)$ & $(0.045)$ & $(0.046)$ & $(0.060)$ & $(0.095)$ & $(0.145)$ \\
Mexico & $0.164^{* * *}$ & $0.201^{* *}$ & $0.156^{* * *}$ & $0.101^{*}$ & 0.082 & 0.060 & 0.104 & $0.176^{* * *}$ & $0.133^{* *}$ & $0.171^{* * *}$ \\
& $(0.039)$ & $(0.079)$ & $(0.051)$ & $(0.061)$ & $(0.068)$ & $(0.071)$ & $(0.075)$ & $(0.064)$ & $(0.052)$ & $(0.053)$ \\
Russia & $0.148^{* * *}$ & $0.149^{* *}$ & $0.127^{* * *}$ & $0.148^{* * *}$ & $0.157^{* * *}$ & $0.148^{* * *}$ & $0.145^{* * *}$ & $0.178^{* * *}$ & $0.201^{* * *}$ & $0.226^{* * *}$ \\
& $(0.023)$ & $(0.079)$ & $(0.033)$ & $(0.028)$ & $(0.022)$ & $(0.023)$ & $(0.038)$ & $(0.051)$ & $(0.055)$ & $(0.047)$ \\
Thailand & $0.131^{* * *}$ & 0.085 & $0.082^{* *}$ & $0.111^{* * *}$ & $0.115^{* * *}$ & $0.131^{* * *}$ & $0.137^{* * *}$ & $0.152^{* * *}$ & $0.194^{* * *}$ & $0.212^{* * *}$ \\
& $(0.032)$ & $(0.079)$ & $(0.044)$ & $(0.028)$ & $(0.026)$ & $(0.024)$ & $(0.022)$ & $(0.027)$ & $(0.039)$ & $(0.069)$ \\
Pool data & $0.133^{* * *}$ & $0.144^{* * *}$ & $0.126^{* * *}$ & $0.119^{* * *}$ & $0.121^{* * *}$ & $0.119^{* * *}$ & $0.124^{* * *}$ & $0.120^{* * *}$ & $0.110^{* * *}$ & $0.130^{* * * *}$ \\
& $(0.009)$ & $(0.018)$ & $(0.014)$ & $(0.012)$ & $(0.011)$ & $(0.011)$ & $(0.010)$ & $(0.011)$ & $(0.018)$ & $(0.016)$ \\
\hline
\end{tabular}

Note: ${ }^{* * *},{ }^{* *}$ and ${ }^{*}$ show the significance at the level of $1 \%, 5 \%$ and $10 \%$, respectively. Standard error is provided in parentheses. The independent variable is bank credit and the dependant variable is the business cycle. The number of bootstrap replication is 200. 
The interesting points lie in the results of the panel quantile regression; Table 4.5 demonstrates that bank credit has larger positive influences on the business cycle in the lower quantiles and higher quantiles, which forms a U-shaped curve. This suggests that bank credit has larger effects on the economy in the trough and in the peak. It partially supports the opinions of Adrian and Shin (2010). They believe the bank is more likely to provide more credit to the business during economic booms. Lo and Piger (2005) and Santoro et al. (2014) find that monetary policy innovations have greater impacts on the output during contractions, which explains the reasons that the effects of bank credit are larger in the trough.

Table 4.5 The results of the panel quantile regression

\begin{tabular}{|c|c|c|c|c|c|c|}
\hline Business cycle & FGLS & $10 \%$ & $30 \%$ & $50 \%$ & $70 \%$ & $90 \%$ \\
\hline \multirow{2}{*}{ Bank credit (-1) } & $0.054^{* * *}$ & $0.057^{* * *}$ & $0.043^{* * *}$ & $0.045^{* * *}$ & $0.062^{* * *}$ & $0.100^{* * *}$ \\
\hline & $(0.006)$ & $(0.000)$ & $(0.003)$ & $(0.001)$ & $(0.000)$ & $(0.000)$ \\
\hline \multirow[t]{2}{*}{ Post financial crisis } & $-0.003^{* * *}$ & $-0.002^{* * *}$ & $-0.001^{* * *}$ & 0.0003 & $-0.003^{* * *}$ & $-0.006^{* * *}$ \\
\hline & $(0.001)$ & $(0.000)$ & $(0.000)$ & $(0.0003)$ & $(0.000)$ & $(0.000)$ \\
\hline \multirow[t]{2}{*}{ Fiscal expenditure $(-1)$} & $0.031^{* *}$ & $0.026^{* * *}$ & $0.030^{* * *}$ & $0.030^{* * *}$ & $0.040^{* * *}$ & $0.085^{* * *}$ \\
\hline & $(0.013)$ & $(0.001)$ & $(0.002)$ & $(0.002)$ & $(0.000)$ & $(0.000)$ \\
\hline \multirow[t]{2}{*}{ Trade openness $(-1)$} & $0.018^{* * *}$ & $0.004^{* * *}$ & $0.009^{* * *}$ & $0.008^{* * *}$ & $0.055^{* * *}$ & $0.075^{* * *}$ \\
\hline & $(0.006)$ & $(0.000)$ & $(0.002)$ & $(0.001)$ & $(0.000)$ & $(0.000)$ \\
\hline \multirow[t]{2}{*}{ Oil price $(-1)$} & $0.018^{* * *}$ & $0.031^{* * *}$ & $0.019^{* * *}$ & $0.018^{* * *}$ & $0.011^{* * *}$ & $0.008^{* * *}$ \\
\hline & $(0.002)$ & $(0.000)$ & $(0.001)$ & $(0.001)$ & $(0.000)$ & $(0.000)$ \\
\hline Observations & 1129 & 1129 & 1129 & 1129 & 1129 & 1129 \\
\hline $\mathrm{N}$ & 18 & 18 & 18 & 18 & 18 & 18 \\
\hline
\end{tabular}

$G D P_{i t}=\beta_{1}$ CREDIT $_{i t-1}+\beta_{2}$ POST $_{t}+\beta_{3} G O V_{i t-1}+\beta_{4} T R A D E_{i t-1}+\beta_{5} O I L_{t-1}+\varepsilon_{i t}$ 
Table 4.6 The results of the panel quantile regression in the advanced and emerging countries

\begin{tabular}{|c|c|c|c|c|c|c|}
\hline Business cycle & FGLS & $10 \%$ & $30 \%$ & $50 \%$ & $70 \%$ & $90 \%$ \\
\hline \multicolumn{7}{|c|}{ Advanced countries } \\
\hline \multirow[t]{2}{*}{ Bank credit (-1) } & $0.043^{* * *}$ & $0.041^{* * *}$ & $0.018^{* * *}$ & $0.031^{* * *}$ & $0.042^{* * * *}$ & $0.073^{* * *}$ \\
\hline & $(0.007)$ & $(0.002)$ & $(0.001)$ & $(0.003)$ & $(0.001)$ & $(0.000)$ \\
\hline \multirow[t]{2}{*}{ Post financial crisis } & $-0.003^{* * *}$ & $-0.004^{* * *}$ & $0.003^{* * *}$ & 0.0004 & $-0.003^{* * *}$ & $-0.008^{* * *}$ \\
\hline & $(0.001)$ & $(0.000)$ & $(0.001)$ & $(0.002)$ & $(0.000)$ & $(0.000)$ \\
\hline \multirow[t]{2}{*}{ Fiscal expenditure $(-1)$} & $-0.063^{*}$ & $0.068^{* * * *}$ & $0.035^{* *}$ & -0.034 & $-0.064^{* * *}$ & $0.272^{* * *}$ \\
\hline & $(0.037)$ & $(0.005)$ & $(0.014)$ & $(0.021)$ & $(0.004)$ & $(0.000)$ \\
\hline \multirow[t]{2}{*}{ Trade openness (-1) } & $0.132^{* * *}$ & $0.048^{* * *}$ & $0.061^{* * *}$ & $0.078^{* * *}$ & $0.090^{* * *}$ & $0.137^{* * *}$ \\
\hline & $(0.016)$ & $(0.001)$ & $(0.004)$ & $(0.003)$ & $(0.002)$ & $(0.000)$ \\
\hline \multirow[t]{2}{*}{ Oil price $(-1)$} & $0.008^{* * *}$ & $0.023^{* * *}$ & $0.007^{* * *}$ & 0.007 & $0.005^{* * *}$ & $0.004^{* * *}$ \\
\hline & $(0.002)$ & $(0.000)$ & $(0.002)$ & $(0.006)$ & $(0.000)$ & $(0.000)$ \\
\hline Observations & 636 & 636 & 636 & 636 & 636 & 636 \\
\hline $\mathrm{N}$ & 9 & 9 & 9 & 9 & 9 & 9 \\
\hline \multicolumn{7}{|c|}{ Emerging countries } \\
\hline \multirow[t]{2}{*}{ Bank credit (-1) } & $0.066^{* * *}$ & $0.062^{* * *}$ & $0.096^{* * *}$ & $0.085^{* * *}$ & $0.086^{* * * *}$ & $0.098^{* * * *}$ \\
\hline & $(0.010)$ & $(0.001)$ & $(0.002)$ & $(0.000)$ & $(0.000)$ & $(0.001)$ \\
\hline \multirow[t]{2}{*}{ Post financial crisis } & $-0.002^{* *}$ & $-0.001^{* * *}$ & $-0.003^{* * *}$ & $-0.0005^{* * *}$ & $-0.001^{* * *}$ & $-0.006^{* * * *}$ \\
\hline & $(0.001)$ & $(0.000)$ & $(0.000)$ & $(0.0000)$ & $(0.000)$ & $(0.000)$ \\
\hline \multirow[t]{2}{*}{ Fiscal expenditure (-1) } & $0.038^{* * *}$ & $0.003^{* * *}$ & $0.017^{* * *}$ & $0.049^{* * *}$ & $0.041^{* * * *}$ & $0.057^{* * *}$ \\
\hline & $(0.014)$ & $(0.001)$ & $(0.002)$ & $(0.000)$ & $(0.000)$ & $(0.001)$ \\
\hline \multirow[t]{2}{*}{ Trade openness (-1) } & -0.001 & $-0.005^{* * *}$ & $-0.007^{* * *}$ & $-0.007^{* * *}$ & $-0.012^{* * *}$ & $-0.004^{* * * *}$ \\
\hline & $(0.005)$ & $(0.001)$ & $(0.001)$ & $(0.000)$ & $(0.000)$ & $(0.000)$ \\
\hline \multirow[t]{2}{*}{ Oil price $(-1)$} & $0.022^{* * *}$ & $0.042^{* * * *}$ & $0.022^{* * *}$ & $0.016^{* * *}$ & $0.016^{* * *}$ & $0.017^{* * *}$ \\
\hline & $(0.003)$ & $(0.001)$ & $(0.001)$ & $(0.000)$ & $(0.000)$ & $(0.000)$ \\
\hline Observations & 493 & 493 & 493 & 493 & 493 & 493 \\
\hline $\mathrm{N}$ & 9 & 9 & 9 & 9 & 9 & 9 \\
\hline
\end{tabular}

Note: ${ }^{* * *},{ }^{* *}$ and ${ }^{*}$ show the significance at the level of $1 \%, 5 \%$ and $10 \%$, respectively. Standard error is provided in parentheses. The PQRD model uses the adaptive MCMC optimization procedure to specify. The number of draws to perform is 1000 and the number of draws to drop as a burn-in period is 100 . The acceptance rate of the algorithm is 0.5 . The results are obtained by estimating the model:

$G D P_{i t}=\beta_{1}$ CREDIT $_{i t-1}+\beta_{2}$ POST $_{t}+\beta_{3} G O V_{i t-1}+\beta_{4} T R A D E_{i t-1}+\beta_{5} O I L_{t-1}+\varepsilon_{i t}$

Besides, I observe that the dummy variable of the post financial crisis has a significant and negative effect in the most quantiles. Its negative effect is larger in the lower quantiles 
and higher quantiles, which shows an inverted U-shaped curve. It shows the higher capital requirement and the more risk-sensitiveness standard set by the bank after the financial crisis, which negatively affects the business cycle, such as Basel II. Pederzoli and Torricelli (2005) confirm that Basel II could worsen the business cycle due to the reduction in credit availability in recession periods. In the control variables, it is evident that fiscal expenditure has the expected significant positive effects on the business cycle and its effects increase as the quantile points increase. Trade openness and oil price also have expected positive effects on the business cycle. The effects of trade openness increase with the increase of the quantile points but the effects of oil price decrease with the increase of quantile points.

Regarding the different cyclical fluctuations in the advanced and emerging countries (Kose et al., 2003; Calderón and Fuentes, 2014), I split the whole sample into the advanced and emerging countries. Table 4.6 demonstrates that most variables keep their expected effects on the business cycle. In the results of the FGLS estimation, bank credit and oil price have significant positive effects on the business cycle in the two groups of countries. The dummy variable of the post financial crisis negatively affects the business cycle. The effects of bank credit and oil price are larger on the business cycle in the emerging countries. Fiscal expenditure has a significant negative effect on the advanced countries and has a significant positive effect on the emerging countries, respectively. This suggests that fiscal expenditure is counter-cyclical or pro-cyclical with the business cycle in the 
different countries. The effect of trade openness on the business cycle is significant positive in the advanced countries but is not significant in the emerging countries.

Compared with the results of the advanced and the emerging countries in the panel quantile regression, I observe that bank credit has larger positive effects in the business cycle in the emerging countries than the advanced countries. This finding supports that the business cycle is more amplified by bank credit in the emerging countries (see Claessens et al., 2012). They argue that the relationship between the business cycle and bank credit is particularly important in the emerging countries relative to the advanced countries. Furthermore, the dummy variable of the post financial crisis negatively affects both advanced and emerging countries. In the control variables, the effects of fiscal expenditure and trade openness are mixed in the advanced countries and emerging countries, respectively. The effects of fiscal expenditure and trade openness on the business cycle increase with the increase of quantile points in the advanced countries and emerging countries, respectively. The effects of oil price decrease in line with the increase of quantile points in the advanced and emerging countries.

\subsection{Robustness tests}

The external economic factors might affect the business cycle (Duarte et al., 2007;

Claessens et al., 2012). I add world output and foreign exchange rate in the regression 
models ${ }^{27}$. Table 4.7 shows very similar results as above where bank credit has a positive U-shaped influence on the business cycle while the dummy variable of the post financial crisis has a negative inverted U-shaped effect on the business cycle. Fiscal expenditure has the expected positive effects on the business cycle and the effects of fiscal expenditure increase with the increase of quantile points. Furthermore, world output has the significant positive effects on the business cycle. This finding confirms the co-movement of the international business cycles (Kose and Yi, 2006; Faia, 2007; Kose, et al., 2008; Claessens et al., 2012). The roles of world output are significantly larger in the middle and higher quantiles points. Furthermore, foreign exchange rate negatively affects the business cycle since the appreciation of local currency could dampen the shocks from the external factors and then negatively affect the business cycle. The negative effects of foreign exchange rate increase in line the increase of the quantile points.

Regarding the results in the advanced countries and emerging countries, Table 4.8 shows that bank credit and world output have significant positive effects on the business cycle for both types of countries, whose positive effects are larger in the emerging countries. The dummy variable of the post financial crisis and foreign exchange rate have a negative relationship with the business cycle in the advanced countries and emerging countries. The negative effects of foreign exchange rate are larger in the emerging countries.

\footnotetext{
${ }^{27}$ Since trade openness and oil price are highly correlated with world output and foreign exchange rate, I do not use trade openness and oil price in the original regression models.
} 
Table 4.7 The results of the panel quantile regression with additional control variables

\begin{tabular}{lcccccc}
\hline Business cycle & FGLS & $10 \%$ & $30 \%$ & $50 \%$ & $70 \%$ & $90 \%$ \\
\hline Bank credit (-1) & $0.069^{* * * *}$ & $0.111^{* * *}$ & $0.095^{* * *}$ & $0.091^{* * *}$ & $0.092^{* * * *}$ & $0.099^{* * * *}$ \\
& $(0.008)$ & $(0.000)$ & $(0.003)$ & $(0.004)$ & $(0.002)$ & $(0.000)$ \\
Post financial crisis & $-0.002^{* *}$ & $-0.003^{* * *}$ & $-0.001^{*}$ & $-0.001^{* * *}$ & -0.0001 & $-0.003^{* * *}$ \\
& $(0.001)$ & $(0.000)$ & $(0.000)$ & $(0.000)$ & $(0.0002)$ & $(0.000)$ \\
Fiscal expenditure (-1) & $0.028^{* * * *}$ & $0.050^{* * *}$ & $0.033^{* * *}$ & $0.026^{* * *}$ & $0.052^{* * * *}$ & $0.097^{* * * *}$ \\
& $(0.011)$ & $(0.000)$ & $(0.002)$ & $(0.001)$ & $(0.001)$ & $(0.000)$ \\
World output (-1) & $-0.024^{* * *}$ & $-0.053^{* * * *}$ & $-0.053^{* * *}$ & $-0.053^{* * *}$ & $-0.059^{* * *}$ & $-0.054^{* * *}$ \\
& $(0.009)$ & $(0.000)$ & $(0.003)$ & $(0.003)$ & $(0.002)$ & $(0.000)$ \\
Foreign exchange (-1) & $0.718^{* * * *}$ & $0.734^{* * *}$ & $0.699^{* * *}$ & $0.723^{* * *}$ & $0.764^{* * *}$ & $0.611^{* * *}$ \\
& $(0.030)$ & $(0.000)$ & $(0.046)$ & $(0.017)$ & $(0.004)$ & $(0.001)$ \\
Observations & 1158 & 1158 & 1158 & 1158 & 1158 & 1158 \\
$\mathrm{~N}$ & 18 & 18 & 18 & 18 & 18 & 18 \\
\hline
\end{tabular}

Note: ${ }^{* * *},{ }^{* *}$ and ${ }^{*}$ show the significance at the level of $1 \%, 5 \%$ and $10 \%$, respectively. Standard error is provided in parentheses. The PQRD model uses the adaptive MCMC optimization procedure to specify. The number of draws to perform is 1000 and the number of draws to drop as a burn-in period is 100 . The acceptance rate of the algorithm is 0.5 . The results are obtained by estimating the model:

$G D P_{i t}=\beta_{1} C R E D I T_{i t-1}+\beta_{2} P O S T_{t}+\beta_{3} G O V_{i t-1}+\beta_{4} O U T P U T_{t-1}+\beta_{5} F X_{i t-1}+\varepsilon_{i t}$

In order to ascertain the dynamic patterns of the business cycle, I apply the dynamic panel regressions. In the results of the Arellano-Bond GMM estimation, Table 4.9 shows that the first lagged detrended GDP has a significant positive impact on the business cycle, which presents the dynamic patterns of the business cycle. Besides, bank credit, the dummy variable of the post financial crisis, fiscal expenditure and oil price keep their expected effects on the business cycle but the impact of trade openness is not significant. In the results of the dynamic panel quantile regression, it is evident that the autocorrelation of the business cycle is small in the lower quantiles and increase in line with the increase of quantile points. In addition, the effect of bank credit shows a U-shaped curve and the negative impacts of the dummy variable of the post financial crisis are larger in the lower 
quantiles and higher quantiles. The impacts of fiscal expenditure are larger in the higher quantiles and the impacts of oil price are lower in the lower quantiles.

Table 4.8 The results of the panel quantile regression in the advanced and emerging countries with additional control variables

\begin{tabular}{|c|c|c|c|c|c|c|}
\hline Business cycle & FGLS & $10 \%$ & $30 \%$ & $50 \%$ & $70 \%$ & $90 \%$ \\
\hline \multicolumn{7}{|c|}{ Advanced countries } \\
\hline \multirow[t]{2}{*}{ Bank credit (-1) } & $0.056^{* * *}$ & $0.129^{* * *}$ & $0.055^{* * *}$ & $0.092^{* * * *}$ & $0.068^{* * * *}$ & $0.103^{* * *}$ \\
\hline & $(0.010)$ & $(0.004)$ & $(0.002)$ & $(0.007)$ & $(0.000)$ & $(0.001)$ \\
\hline \multirow[t]{2}{*}{ Post financial crisis } & $-0.003^{* * *}$ & $-0.002^{* * *}$ & $-0.0004^{* * *}$ & -0.001 & $-0.003^{* * *}$ & $-0.005^{* * *}$ \\
\hline & $(0.001)$ & $(0.000)$ & $(0.0001)$ & $(0.001)$ & $(0.000)$ & $(0.000)$ \\
\hline \multirow[t]{2}{*}{ Fiscal expenditure (-1) } & $-0.095^{* * *}$ & $0.138^{* * * *}$ & $-0.011^{* * *}$ & $-0.030^{*}$ & $-0.063^{* * *}$ & $0.178^{* * * *}$ \\
\hline & $(0.034)$ & $(0.010)$ & $(0.004)$ & $(0.018)$ & $(0.000)$ & $(0.003)$ \\
\hline \multirow[t]{2}{*}{ World output (-1) } & $0.619^{* * *}$ & $0.545^{* * *}$ & $0.707^{* * *}$ & $0.663^{* * *}$ & $0.648^{* * *}$ & $0.634^{* * * *}$ \\
\hline & $(0.038)$ & $(0.019)$ & $(0.003)$ & $(0.046)$ & $(0.001)$ & $(0.001)$ \\
\hline \multirow[t]{2}{*}{ Foreign exchange (-1) } & $-0.024^{*}$ & $-0.098^{* * *}$ & $-0.048^{* * *}$ & $-0.080^{* * *}$ & $-0.057^{* * *}$ & $-0.107^{* * * *}$ \\
\hline & $(0.013)$ & $(0.003)$ & $(0.003)$ & $(0.008)$ & $(0.000)$ & $(0.000)$ \\
\hline Observations & 636 & 636 & 636 & 636 & 636 & 636 \\
\hline $\mathrm{N}$ & 9 & 9 & 9 & 9 & 9 & 9 \\
\hline \multicolumn{7}{|c|}{ Emerging countries } \\
\hline \multirow[t]{2}{*}{ Bank credit (-1) } & $0.087^{* * *}$ & $0.092^{* * * *}$ & $0.112^{* * * *}$ & $0.106^{* * *}$ & $0.135^{* * * *}$ & $0.106^{* * * *}$ \\
\hline & $(0.011)$ & $(0.000)$ & $(0.000)$ & $(0.004)$ & $(0.001)$ & $(0.004)$ \\
\hline \multirow[t]{2}{*}{ Post financial crisis } & -0.001 & $-0.003^{* * *}$ & $-0.001^{* * *}$ & 0.001 & $-0.002^{* * *}$ & $-0.002^{* * *}$ \\
\hline & $(0.001)$ & $(0.000)$ & $(0.000)$ & $(0.001)$ & $(0.000)$ & $(0.000)$ \\
\hline \multirow[t]{2}{*}{ Fiscal expenditure (-1) } & $0.034^{* * *}$ & $0.008^{* * *}$ & $0.025^{* * *}$ & $0.035^{* * *}$ & $0.069^{* * * *}$ & $0.082^{* * * *}$ \\
\hline & $(0.011)$ & $(0.000)$ & $(0.001)$ & $(0.003)$ & $(0.001)$ & $(0.003)$ \\
\hline \multirow[t]{2}{*}{ World output (-1) } & $0.833^{* * *}$ & $0.929^{* * * *}$ & $0.859^{* * *}$ & 0.434 & $0.720^{* * * *}$ & $0.747^{* * * *}$ \\
\hline & $(0.052)$ & $(0.001)$ & $(0.002)$ & $(0.361)$ & $(0.002)$ & $(0.017)$ \\
\hline \multirow[t]{2}{*}{ Foreign exchange (-1) } & $-0.029^{* *}$ & $-0.008^{* * *}$ & $-0.043^{* * * *}$ & $-0.052^{* * *}$ & $-0.070^{* * * *}$ & $-0.072^{* * * *}$ \\
\hline & $(0.012)$ & $(0.000)$ & $(0.000)$ & $(0.001)$ & $(0.001)$ & $(0.008)$ \\
\hline Observations & 522 & 522 & 522 & 522 & 522 & 522 \\
\hline $\mathrm{N}$ & 9 & 9 & 9 & 9 & 9 & 9 \\
\hline
\end{tabular}

Note: ${ }^{* * *},{ }^{* *}$ and ${ }^{*}$ show the significance at the level of $1 \%, 5 \%$ and $10 \%$, respectively. Standard error is provided in parentheses. The PQRD model uses the adaptive MCMC optimization procedure to specify. The number of draws to perform is 1000 and the number of draws to drop as a burn-in period is 100 . The acceptance rate of the algorithm is 0.5 . The results are obtained by estimating the model:

$G D P_{i t}=\beta_{1}$ CREDIT $_{i t-1}+\beta_{2}$ POST $_{t}+\beta_{3} G O V_{i t-1}+\beta_{4} O U T P U T_{t-1}+\beta_{5} F X_{i t-1}+\varepsilon_{i t}$ 
Table 4.9 The results of the dynamic panel quantile regression

\begin{tabular}{lcccccc}
\hline Business cycle & GMM & $10 \%$ & $30 \%$ & $50 \%$ & $70 \%$ & $90 \%$ \\
\hline GDP (-1) & $0.740^{* * * *}$ & $0.702^{* * * *}$ & $0.771^{* * *}$ & $0.778^{* * *}$ & $0.773^{* * * *}$ & $0.769^{* * *}$ \\
& $(0.018)$ & $(0.001)$ & $(0.000)$ & $(0.001)$ & $(0.001)$ & $(0.000)$ \\
Bank credit (-1) & $0.020^{* * *}$ & $0.030^{* * * *}$ & $0.017^{* * * *}$ & $0.007^{* * *}$ & $0.013^{* * * *}$ & $0.022^{* * *}$ \\
& $(0.005)$ & $(0.000)$ & $(0.000)$ & $(0.001)$ & $(0.000)$ & $(0.000)$ \\
Post financial crisis & $-0.003^{* * *}$ & $-0.002^{* * *}$ & $-0.0001^{* * *}$ & $-0.001^{* * * *}$ & $-0.001^{* * *}$ & $-0.003^{* * *}$ \\
& $(0.001)$ & $(0.000)$ & $(0.0000)$ & $(0.000)$ & $(0.000)$ & $(0.000)$ \\
Fiscal expenditure (-1) & $0.015^{*}$ & $0.009^{* * * *}$ & $0.006^{* * *}$ & $0.017^{* * *}$ & $0.018^{* * * *}$ & $0.030^{* * *}$ \\
& $(0.009)$ & $(0.000)$ & $(0.000)$ & $(0.001)$ & $(0.000)$ & $(0.000)$ \\
Trade openness (-1) & -0.005 & $0.003^{* * * *}$ & $0.001^{* * *}$ & $-0.002^{* * * *}$ & 0.0000 & $0.009^{* * *}$ \\
& $(0.005)$ & $(0.000)$ & $(0.000)$ & $(0.001)$ & $(0.0001)$ & $(0.000)$ \\
Oil price (-1) & $0.006^{* * *}$ & $0.008^{* * * *}$ & $0.003^{* * *}$ & $0.003^{* * *}$ & $0.003^{* * * *}$ & $-0.0003^{* * *}$ \\
& $(0.001)$ & $(0.000)$ & $(0.000)$ & $(0.000)$ & $(0.000)$ & $(0.0000)$ \\
Observations & 1111 & 1129 & 1129 & 1129 & 1129 & 1129 \\
$\mathrm{~N}$ & 18 & 18 & 18 & 18 & 18 & 18 \\
\hline
\end{tabular}

Note: ${ }^{* * *},{ }^{* *}$ and ${ }^{*}$ show the significance at the level of $1 \%, 5 \%$ and $10 \%$, respectively. Standard error is provided in parentheses. The PQRD model uses the adaptive MCMC optimization procedure to specify. The number of draws to perform is 1000 and the number of draws to drop as a burn-in period is 100 . The acceptance rate of the algorithm is 0.5 . The results are obtained by estimating the model:

$G D P_{i t}=\beta_{1} G D P_{i t-1}+\beta_{2} C R E D I T_{i t-1}+\beta_{3} P O S T_{t}+\beta_{4} G O V_{i t-1}+\beta_{5} T R A D E_{i t-1}+\beta_{6} O I L_{t-1}+\varepsilon_{i t}$

Table 4.10 shows that in the results of the Arellano-Bond GMM estimation, the first lagged detrended GDP, bank credit and the dummy variable of the post financial crisis have the significant negative impacts in the business cycle in the advanced and emerging countries. The roles of fiscal expenditure, trade openness and oil price are mixed in the both groups of countries. In the results of the dynamic panel quantile regression, the autocorrelation of the business cycle is small in the lower quantiles and increase in line with the increase of quantile points. The effect of bank credit shows a U-shaped curve and the negative impact of the dummy variable of post financial crisis is larger in the lower 
quantiles and the higher quantiles. The autocorrelation of the business cycle is larger in the advanced countries and the roles of bank credit are larger in the emerging countries.

Furthermore, I investigate the effects of bank credit on the business cycle in the different horizons by using $1^{\text {st }}, 2^{\text {nd }}, 3^{\text {rd }}$ and $4^{\text {th }} \operatorname{lags}^{28}$, respectively. Table 4.11 demonstrates that in the whole sample, the results of the Arellano-Bond GMM estimation reveal that the bank credits from the first lag to the fourth lag have significant effects on the business cycle. The positive effects become the greatest in the second lagged period and then gradually decrease. In the results of the panel quantile regression, the effect of the lagged bank credit shows a U-shaped curve on the business cycle from the first lag to the fourth lag except the coefficients in the third lag in the advanced countries. The results suggest that the effects of bank credit diminish as time goes by (see Mimir, 2016). He finds that financial variables result in the output fluctuations from one to three quarters. Compared with the advanced and emerging countries, it is evident that the effects of bank credit in the emerging countries are also larger than the advanced countries in all the lags.

\footnotetext{
${ }^{28}$ I do not report the results of the other variables in the regression models in the different horizons because of the limited space.
} 
Table 4.10 The results of the dynamic panel quantile regression in the advanced and emerging countries

\begin{tabular}{|c|c|c|c|c|c|c|}
\hline Business cycle & GMM & $10 \%$ & $30 \%$ & $50 \%$ & $70 \%$ & $90 \%$ \\
\hline \multicolumn{7}{|c|}{ Advanced countries } \\
\hline \multirow[t]{2}{*}{ GDP (-1) } & $0.781^{* * * *}$ & $0.778^{* * *}$ & $0.809^{* * *}$ & $0.794^{* * * *}$ & $0.804^{* * * *}$ & $0.812^{* * * *}$ \\
\hline & $(0.023)$ & $(0.000)$ & $(0.000)$ & $(0.000)$ & $(0.000)$ & $(0.001)$ \\
\hline \multirow[t]{2}{*}{ Bank credit (-1) } & $0.018^{* * *}$ & $0.025^{* * *}$ & $0.009^{* * * *}$ & $0.010^{* * * *}$ & $0.017^{* * * *}$ & $0.019^{* * *}$ \\
\hline & $(0.006)$ & $(0.000)$ & $(0.000)$ & $(0.000)$ & $(0.000)$ & $(0.000)$ \\
\hline \multirow[t]{2}{*}{ Post financial crisis } & $-0.002^{* *}$ & $-0.001^{* * *}$ & $-0.0001^{* * *}$ & $-0.0001^{* * *}$ & $-0.002^{* * *}$ & $-0.004^{* * *}$ \\
\hline & $(0.001)$ & $(0.000)$ & $(0.000)$ & $(0.0000)$ & $(0.000)$ & $(0.000)$ \\
\hline \multirow[t]{2}{*}{ Fiscal expenditure (-1) } & 0.005 & $-0.037^{* * *}$ & $-0.044^{* * *}$ & $-0.015^{* * *}$ & $-0.015^{* * *}$ & $0.046^{* * *}$ \\
\hline & $(0.022)$ & $(0.000)$ & $(0.000)$ & $(0.000)$ & $(0.000)$ & $(0.002)$ \\
\hline \multirow[t]{2}{*}{ Trade openness (-1) } & 0.007 & $0.010^{* * *}$ & $0.019^{* * *}$ & $0.016^{* * *}$ & $0.016^{* * *}$ & $0.001^{* * * *}$ \\
\hline & $(0.008)$ & $(0.000)$ & $(0.000)$ & $(0.000)$ & $(0.000)$ & $(0.000)$ \\
\hline \multirow[t]{2}{*}{ Oil price $(-1)$} & 0.001 & $0.004^{* * *}$ & $0.001^{* * * *}$ & $-0.001^{* * *}$ & $-0.002^{* * *}$ & $0.001^{* * *}$ \\
\hline & $(0.002)$ & $(0.000)$ & $(0.000)$ & $(0.000)$ & $(0.000)$ & $(0.000)$ \\
\hline Observations & 627 & 636 & 636 & 636 & 636 & 636 \\
\hline $\mathrm{N}$ & 9 & 9 & 9 & 9 & 9 & 9 \\
\hline \multicolumn{7}{|c|}{ Emerging countries } \\
\hline \multirow[t]{2}{*}{ GDP (-1) } & $0.666^{* * *}$ & $0.598^{* * *}$ & $0.738^{* * *}$ & $0.762^{* * * *}$ & $0.756^{* * * *}$ & $0.715^{* * *}$ \\
\hline & $(0.030)$ & $(0.000)$ & $(0.000)$ & $(0.000)$ & $(0.000)$ & $(0.011)$ \\
\hline \multirow[t]{2}{*}{ Bank credit (-1) } & $0.023^{* * *}$ & $0.040^{* * *}$ & $0.028^{* * *}$ & $0.018^{* * *}$ & $0.014^{* * *}$ & $0.025^{* * *}$ \\
\hline & $(0.008)$ & $(0.000)$ & $(0.000)$ & $(0.000)$ & $(0.000)$ & $(0.004)$ \\
\hline \multirow[t]{2}{*}{ Post financial crisis } & $-0.003^{* * *}$ & $-0.0002^{* * *}$ & $0.0001^{* * *}$ & $-0.001^{* * *}$ & $-0.002^{* * *}$ & $-0.002^{* * *}$ \\
\hline & $(0.001)$ & $(0.0000)$ & $(0.0000)$ & $(0.000)$ & $(0.000)$ & $(0.000)$ \\
\hline \multirow[t]{2}{*}{ Fiscal expenditure (-1) } & 0.014 & $0.001^{* * *}$ & $0.009^{* * *}$ & $0.022^{* * *}$ & $0.032^{* * *}$ & $0.013^{* * *}$ \\
\hline & $(0.011)$ & $(0.000)$ & $(0.000)$ & $(0.000)$ & $(0.000)$ & $(0.004)$ \\
\hline \multirow[t]{2}{*}{ Trade openness (-1) } & $-0.010^{*}$ & $-0.073^{* * *}$ & $-0.005^{* * *}$ & $-0.004^{* * *}$ & $-0.003^{* * *}$ & -0.002 \\
\hline & $(0.006)$ & $(0.000)$ & $(0.000)$ & $(0.000)$ & $(0.000)$ & $(0.003)$ \\
\hline \multirow[t]{2}{*}{ Oil price (-1) } & $0.012^{* * *}$ & $0.020^{* * *}$ & $0.003^{* * * *}$ & $0.004^{* * *}$ & $0.005^{* * *}$ & $0.009^{* * *}$ \\
\hline & $(0.002)$ & $(0.000)$ & $(0.000)$ & $(0.000)$ & $(0.000)$ & $(0.001)$ \\
\hline Observations & 484 & 493 & 493 & 493 & 493 & 493 \\
\hline $\mathrm{N}$ & 9 & 9 & 9 & 9 & 9 & 9 \\
\hline
\end{tabular}

Note: ${ }^{* * *},{ }^{* *}$ and ${ }^{*}$ show the significance at the level of $1 \%, 5 \%$ and $10 \%$, respectively. Standard error is provided in parentheses. The PQRD model uses the adaptive MCMC optimization procedure to specify. The number of draws to perform is 1000 and the number of draws to drop as a burn-in period is 100 . The acceptance rate of the algorithm is 0.5 . The results are obtained by estimating the model:

$G D P_{i t}=\beta_{1} G D P_{i t-1}+\beta_{2} C R E D I T_{i t-1}+\beta_{3} P O S T_{t}+\beta_{4} G O V_{i t-1}+\beta_{5} T R A D E_{i t-1}+\beta_{6} O I L_{t-1}+\varepsilon_{i t}$ 
Table 4.11 The results of the panel quantile regression in the different horizons

\begin{tabular}{|c|c|c|c|c|c|c|}
\hline Business cycle & GMM & $10 \%$ & $30 \%$ & $50 \%$ & $70 \%$ & $90 \%$ \\
\hline \multicolumn{7}{|c|}{ All the countries } \\
\hline \multirow[t]{2}{*}{ Bank credit (-1) } & $0.054^{* * * *}$ & $0.057^{* * * *}$ & $0.043^{\text {*** }}$ & $0.045^{* * * *}$ & $0.062^{* * * *}$ & $0.100^{* * *}$ \\
\hline & $(0.006)$ & $(0.000)$ & $(0.003)$ & $(0.001)$ & $(0.000)$ & $(0.000)$ \\
\hline \multirow[t]{2}{*}{ Bank credit (-2) } & $0.057^{* * *}$ & $0.042^{* * *}$ & $0.031^{* * *}$ & $0.038^{* * * *}$ & $0.042^{* * *}$ & $0.083^{* * *}$ \\
\hline & $(0.006)$ & $(0.001)$ & $(0.001)$ & $(0.003)$ & $(0.000)$ & $(0.000)$ \\
\hline \multirow[t]{2}{*}{ Bank credit (-3) } & $0.043^{* * *}$ & $0.027^{* * * *}$ & $0.025^{* * *}$ & $0.032^{* * * *}$ & $0.044^{* * *}$ & $0.046^{* * *}$ \\
\hline & $(0.006)$ & $(0.000)$ & $(0.001)$ & $(0.008)$ & $(0.000)$ & $(0.003)$ \\
\hline \multirow[t]{2}{*}{ Bank credit (-4) } & $0.054^{* * *}$ & $0.057^{* * * *}$ & $0.043^{* * *}$ & $0.045^{* * *}$ & $0.062^{* * *}$ & $0.100^{* * *}$ \\
\hline & $(0.006)$ & $(0.000)$ & $(0.003)$ & $(0.001)$ & $(0.000)$ & $(0.000)$ \\
\hline \multicolumn{7}{|c|}{ Advanced countries } \\
\hline \multirow[t]{2}{*}{ Bank credit (-1) } & $0.043^{* * *}$ & $0.041^{* * * *}$ & $0.018^{* * * *}$ & $0.031^{* * *}$ & $0.042^{* * *}$ & $0.073^{* * *}$ \\
\hline & $(0.007)$ & $(0.002)$ & $(0.001)$ & $(0.003)$ & $(0.001)$ & $(0.000)$ \\
\hline \multirow[t]{2}{*}{ Bank credit $(-2)$} & $0.046^{* * *}$ & $0.029^{* * * *}$ & $0.021^{* * *}$ & $0.016^{* * *}$ & $0.046^{* * *}$ & $0.111^{* * *}$ \\
\hline & $(0.007)$ & $(0.008)$ & $(0.000)$ & $(0.001)$ & $(0.000)$ & $(0.000)$ \\
\hline \multirow[t]{2}{*}{ Bank credit (-3) } & $0.037^{* * *}$ & $0.129^{* * *}$ & $0.037^{* * *}$ & $0.033^{* * *}$ & $0.018^{* * *}$ & $0.042^{* * *}$ \\
\hline & $(0.007)$ & $(0.000)$ & $(0.000)$ & $(0.000)$ & $(0.003)$ & $(0.000)$ \\
\hline \multirow[t]{2}{*}{ Bank credit (-4) } & $0.043^{* * *}$ & $0.041^{* * * *}$ & $0.018^{* * *}$ & $0.031^{* * * *}$ & $0.042^{* * *}$ & $0.073^{* * *}$ \\
\hline & $(0.007)$ & $(0.002)$ & $(0.001)$ & $(0.003)$ & $(0.001)$ & $(0.000)$ \\
\hline \multicolumn{7}{|c|}{ Emerging countries } \\
\hline \multirow[t]{2}{*}{ Bank credit $(-1)$} & $0.066^{* * *}$ & $0.062^{* * * *}$ & $0.096^{* * *}$ & $0.085^{* * * *}$ & $0.086^{* * *}$ & $0.098^{* * * *}$ \\
\hline & $(0.010)$ & $(0.001)$ & $(0.002)$ & $(0.000)$ & $(0.000)$ & $(0.001)$ \\
\hline \multirow[t]{2}{*}{ Bank credit $(-2)$} & $0.068^{* * *}$ & $0.060^{* * * *}$ & $0.062^{* * *}$ & $0.062^{* * * *}$ & $0.077^{* * *}$ & $0.123^{* * *}$ \\
\hline & $(0.010)$ & $(0.000)$ & $(0.000)$ & $(0.002)$ & $(0.000)$ & $(0.008)$ \\
\hline \multirow[t]{2}{*}{ Bank credit $(-3)$} & $0.052^{* * *}$ & $0.031^{* * * *}$ & $0.070^{* * *}$ & $0.059^{* * *}$ & $0.071^{* * *}$ & $0.079^{* * *}$ \\
\hline & $(0.009)$ & $(0.000)$ & $(0.000)$ & $(0.008)$ & $(0.000)$ & $(0.005)$ \\
\hline \multirow[t]{2}{*}{ Bank credit (-4) } & $0.066^{* * *}$ & $0.062^{* * *}$ & $0.096^{* * *}$ & $0.085^{* * *}$ & $0.086^{* * *}$ & $0.098^{* * *}$ \\
\hline & $(0.010)$ & $(0.001)$ & $(0.002)$ & $(0.000)$ & $(0.000)$ & $(0.001)$ \\
\hline
\end{tabular}

Note: ${ }^{* * *},{ }^{* *}$ and ${ }^{*}$ show the significance at the level of $1 \%, 5 \%$ and $10 \%$, respectively. Standard error is provided in parentheses. The PQRD model uses the adaptive MCMC optimization procedure to specify. The number of draws to perform is 1000 and the number of draws to drop as a burn-in period is 100 . The acceptance rate of the algorithm is 0.5 . Since the limited space, I do not report the coefficients of the other variables. The results are obtained by estimating the model:

$G D P_{i t}=\beta_{1} C R E D I T_{i t-h}+\beta_{2} P_{O S T}+\beta_{3} G O V_{i t-h}+\beta_{4} T R A D E_{i t-h}+\beta_{5} O I L_{t-h}+\varepsilon_{i t}$. The lags (h) are 1, 2, 3 and 4 , respectively. 
The strong correlations between financial cycles and real output cycles in many countries are documented (Claessens et al., 2009, 2012; Ma and Zhang, 2016). They show that financial factors (e.g. credit supply and equity price) play a significant role in explaining the duration and amplitude of the different phases of the business cycle. Garcia and Schaller (2002), Lo and Piger (2005) and Santoro et al. (2014) document the significant effects of monetary policy on the business cycle. In line with their findings, I also test the asymmetric roles of the alternative financial factors on the business cycle, such as M2 supply and stock price.

In the results of the FGLS estimation, Table 4.12 shows that M2 supply has a positive effect on the business cycle in all the countries. By splitting the advanced and emerging countries, I observe that M2 supply has significant positive impacts on the business cycle in both groups of countries but the impact of M2 supply on the business cycle is smaller in the advanced countries than in the emerging countries. I also employ the panel quantile regression to explore the different effects of monetary policy in the economic recessions and expansions (Garcia and Schaller, 2002; Lo and Piger, 2005; Santoro et al. 2014). The results show that the effects of M2 supply are significant and larger in the lower quantiles and higher quantiles, which also forms a U-shape curve like the effects of bank credit. It demonstrates that M2 supply could help economy recover in the recessions and might lead to overheating in the expansions. It is evident that the effects of M2 supply also form a 
U-shape for both groups of the countries. In the higher and lower quantiles, the advanced countries have the larger effects of M2 supply than the emerging countries.

Similarly, I examine the effects of stock price on the business cycle. In the result of the FGLS estimation in Table 4.13, I find that stock price has a positive effect on the business cycle in all the countries. Compared with results of the advanced and the emerging countries, it is evident that stock price has significant positive impacts on the business cycle in both groups of the countries. However, the impacts on the business cycle in the advanced country are smaller.

Table 4.12 The results of the panel quantile regression with M2 supply

\begin{tabular}{lcccccc}
\hline Business cycle & FGLS & $10 \%$ & $30 \%$ & $50 \%$ & $70 \%$ & $90 \%$ \\
\hline M2 supply (-1) & $0.079^{* * *}$ & $0.064^{* * *}$ & $0.060^{* * *}$ & $0.063^{* * *}$ & $0.069^{* * * *}$ & $0.090^{* * *}$ \\
& $(0.006)$ & $(0.000)$ & $(0.002)$ & $(0.003)$ & $(0.001)$ & $(0.002)$ \\
Observations & 1132 & 1132 & 1132 & 1132 & 1132 & 1132 \\
$\mathrm{~N}$ & 18 & 18 & 18 & 18 & 18 & 18 \\
\hline \multirow{7}{*}{ Advanced countries } \\
\hline M2 supply (-1) & $0.074^{* * *}$ & $0.079^{* * *}$ & $0.057^{* * *}$ & $0.048^{* * *}$ & $0.057^{* * *}$ & $0.164^{* * *}$ \\
& $(0.009)$ & $(0.000)$ & $(0.000)$ & $(0.001)$ & $(0.001)$ & $(0.001)$ \\
Observations & 639 & 639 & 639 & 639 & 639 & 639 \\
$\mathrm{~N}$ & 9 & 9 & 9 & 9 & 9 & 9 \\
\hline \multirow{7}{*}{ M2 supply (-1) } & $0.073^{* * *}$ & $0.052^{* * *}$ & $0.037^{* * *}$ & $0.076^{* * *}$ & $0.079^{* * *}$ & $0.148^{* * *}$ \\
& $(0.008)$ & $(0.000)$ & $(0.000)$ & $(0.000)$ & $(0.000)$ & $(0.014)$ \\
Observations & 493 & 493 & 493 & 493 & 493 & 493 \\
& 9 & 9 & 9 & 9 & 9 & 9
\end{tabular}

Note: ${ }^{* * *},{ }^{* *}$ and ${ }^{*}$ show the significance at the level of $1 \%, 5 \%$ and $10 \%$, respectively. Standard error is provided in parentheses. The PQRD model uses the adaptive MCMC optimization procedure to specify. The number of draws to perform is 1000 and the number of draws to drop as a burn-in period is 100 . The acceptance rate of the algorithm is 0.5 . Since the limited space, I do not report the coefficients of the other variables. The results are obtained by estimating the model:

$G D P_{i t}=\beta_{1} M 2_{i t-1}+\beta_{2} P O S T_{t}+\beta_{3} G O V_{i t-1}+\beta_{4} T R A D E_{i t-1}+\beta_{5} O I L_{t-1}+\varepsilon_{i t}$ 
The results of the panel quantile regression show that the effects of stock price on the business cycle are significant positive in the most quantiles. The effects of stock price are smaller in the lower quantiles and increase in line with the increase of quantiles points. Compared with the advanced and the emerging countries, it is evident that the effects of stock price are larger in the lower quantiles and higher quantiles in the advanced countries. In the emerging countries, the effect of stock price increases as the quantile points increase. It shows that stock price has a smaller positive effect in the recessions and has a larger positive effect in the economic booms.

Table 4.13 The results of the panel quantile regression with stock price

\begin{tabular}{|c|c|c|c|c|c|c|}
\hline Business cycle & FGLS & $10 \%$ & $30 \%$ & $50 \%$ & $70 \%$ & $90 \%$ \\
\hline \multicolumn{7}{|c|}{ All the countries } \\
\hline \multirow[t]{2}{*}{ Stock price $(-1)$} & $0.041^{* * * *}$ & $0.042^{* * * *}$ & $0.041^{* * * *}$ & $0.029^{* * * *}$ & $0.036^{* * *}$ & $0.041^{* * *}$ \\
\hline & $(0.002)$ & $(0.000)$ & $(0.000)$ & $(0.001)$ & $(0.000)$ & $(0.000)$ \\
\hline Observations & 1132 & 1132 & 1132 & 1132 & 1132 & 1132 \\
\hline $\mathrm{N}$ & 18 & 18 & 18 & 18 & 18 & 18 \\
\hline \multicolumn{7}{|c|}{ Advanced countries } \\
\hline \multirow[t]{2}{*}{ Stock price $(-1)$} & $0.038^{* * * *}$ & $0.044^{* * * *}$ & $0.025^{* * * *}$ & $0.028^{* * *}$ & $0.029^{* * *}$ & $0.039^{* * *}$ \\
\hline & $(0.003)$ & $(0.000)$ & $(0.001)$ & $(0.000)$ & $(0.002)$ & $(0.000)$ \\
\hline Observations & 639 & 639 & 639 & 639 & 639 & 639 \\
\hline $\mathrm{N}$ & 9 & 9 & 9 & 9 & 9 & 9 \\
\hline \multicolumn{7}{|c|}{ Emerging countries } \\
\hline \multirow[t]{2}{*}{ Stock price $(-1)$} & $0.040^{* * * *}$ & $0.040^{* * * *}$ & $0.049^{* * *}$ & $0.044^{* * *}$ & $0.044^{* * * *}$ & $0.057^{* * *}$ \\
\hline & $(0.003)$ & $(0.000)$ & $(0.000)$ & $(0.000)$ & $(0.000)$ & $(0.003)$ \\
\hline Observations & 525 & 493 & 493 & 493 & 493 & 493 \\
\hline $\mathrm{N}$ & 9 & 9 & 9 & 9 & 9 & 9 \\
\hline
\end{tabular}

Note: ${ }^{* * *},{ }^{* *}$ and ${ }^{*}$ show the significance at the level of $1 \%, 5 \%$ and $10 \%$, respectively. Standard error is provided in parentheses. The PQRD model uses the adaptive MCMC optimization procedure to specify. The number of draws to perform is 1000 and the number of draws to drop as a burn-in period is 100 . The acceptance rate of the algorithm is 0.5 . Since the limited space, I do not report the coefficients of the other variables. The results are obtained by estimating the model:

$G D P_{i t}=\beta_{1} S_{T O C K_{i t-1}}+\beta_{2} P_{O S T_{t}}+\beta_{3} G O V_{i t-1}+\beta_{4} T R A D E_{i t-1}+\beta_{5} O I L_{t-1}+\varepsilon_{i t}$ 


\subsection{Conclusions}

In this paper, I apply the quantile regression models to investigate the asymmetric roles

of bank credit on the business cycle by using the international evidence. The results show that bank credit is pro-cyclical and has large effects on the business cycle in this peak and trough, which forms a U-shape curve. Compared with the advanced and emerging counties, the effects of bank credit are larger in the emerging countries than advanced countries. The business cycle after the financial crisis is less prone to fluctuations because of the higher capital requirement and the more risk-sensitiveness standard.

In the robustness tests, bank credit has U-shaped effects on the business cycle by using additional control variables and considering the dynamics of business cycle. Besides, the effects of bank credit on the business cycle gradually diminish as time goes by. After using the alternative financial factors, including M2 supply and stock price, this paper suggests that the effects of M2 supply and stock price also show a U- shaped curve, which means that financial factors work well in the economic recessions and booms. This paper contributes to explore the distinct roles of bank credit on the economy in the different business cycle phases. 


\section{BIBLIOGRAPHY}

Abrigo, M., Love, I., 2015, Estimation of panel vector autoregression in Stata: A package of programs. University of Hawaii, Working paper.

Acemoglu, D., Zilibotti, F., 1997. Was prometheus unbound by chance? Risk, diversification and growth. Journal of Political Economy 105 (4), 709-751.

Acemoglu, D., Johnson, S., Robinson, J., Thaicharoen, Y., 2003. Institutional causes, macroeconomic symptoms: Volatility, crises and growth. Journal of Monetary Economics 50 (1), 49-123.

Adrian, T., Shin, H., 2010. Liquidity and leverage. Journal of Financial Intermediation 19 (3), 418-437.

Aghion, P., Banerjee, A., Piketty, T., 1999. Dualism and macroeconomic volatility. Quarterly Journal of Economics 114 (4), 1359-1397.

Aghion, P., Bacchetta, P., Banerjee, A., 2004. Financial development and the instability of open economies. Journal of Monetary Economics 51 (6), 1077-1106.

Aghion, P., Angeletos, M., Banerjee, A., Manova, K., 2009. Exchange rate volatility and productivity growth: The role of financial development. Journal of Monetary Economics 56 (4), 494-513.

Agrast, M., Botero, J., Martinez, J., Ponce, A., Pratt, C., WJP Rule of Law Index 2012-2013. Washington, D. C. The World Justice Project.

Aivazian, V., Ge, Y., Qiu, J., 2005. The impact of leverage on firm investment: Canadian evidence. Journal of Corporate Finance 11 (1), 277-291.

Alesina, A., Campante, F., Tabellini, G., 2008. Why is fiscal policy often procyclical? Journal of the European Economic Association 6 (5), 1006-1036.

Allen, F., Qian, J., Qian, M., 2005. Law, finance, and economic growth in China. Journal of Financial Economics 77 (1), 57-116.

Andrews, D., Lu, B., 2001. Consistent model and moment selection procedures for GMM estimation with application to dynamic panel data models. Journal of Econometrics 101 (1), 123-164. 
Apostoaie, C., Percic, S., 2014. Credit cycles and business cycles in twenty EU economies. Procedia Economics and Finance 15, 1055-1064.

Arcand, J., Berkes, E., Panizza, U., 2012. Too much finance? IMF Working Paper 12/161, International Monetary Fund, Washington, DC.

Arellano, M., Bover, O., 1995. Another look at the instrumental variable estimation of error-components models. Journal of Econometrics 68 (1), 29-52.

Asea, P., Blomberg, B., 1998. Lending cycles. Journal of Econometrics 83 (1-2), 89-128.

Bacchetta, P., Caminal, R., 2000. Do capital market imperfections exacerbate output fluctuations? European Economic Review 44 (3), 449-468.

Bartoletto, S., Chiarini, B., Marzano, E., Piselli, P., 2015. Business cycles, credit cycles and bank holdings of sovereign bonds: Historical evidence for Italy 1861-2013, CESifo Group Munich in its series CESifo Working Paper Series with number 5318.

Baxter, M., Stockman, A. C., 1989. Business cycles and the exchange-rate regime: Some international evidence. Journal of Monetary Economics 23 (3), 377-400.

Beck, T., Demirguc-Kunt, A., Laeven, L., Maksimovic, V., 2006. The determinants of financing obstacles. Journal of International Money and Finance 25 (6), 932-952.

Beck, T., Lundberg, M., Majnoni, G., 2006. Financial intermediary development and growth volatility: Do intermediaries dampen or magnify shocks. Journal of International Money and Finance 25 (7), 1146-1167.

Beck, T., Degryse, H., Kneer, C., 2014. Is more finance better? Disentangling inter-mediation and size effects of financial systems. Journal of Financial Stability 10 (1), 50-64.

Bejan M., 2006. Trade openness and output volatility. MPRA paper 2759.

Bekaert, G., Harvey, C., Lundblad, C., 2006. Growth volatility and financial liberalization. Journal of International Money and Finance 25 (3), 370-403.

Berger, A., Udell, G., 1998. The economics of small business finance: The roles of private equity and debt markets in the financial growth cycle. Journal of Banking \& Finance $22(6-8), 613-673$. 
Bernanke, B., 1983. Nonmonetary effects of the financial crisis in the propagation of the Great Depression. American Economic Review 73 (3), 257-276.

Bernanke, B., Gertler, M., 1989. Agency costs, net worth, and business fluctuations. American Economic Review 79 (1), 14-31.

Bernanke, B., Gertler, M., 1990. Financial fragility and economic performance. Quarterly Journal of Economics 105 (1), 87-114.

Bernanke, B., Gertler, M., 1995. Inside the black box: The credit channel of monetary policy transmission. Journal of Economic Perspectives 9 (4), 27-48.

Bernanke, B., Gertler, M., Gilchrist, S., 1996. The financial accelerator and the flight to quality. Review of Economics and Statistics 78 (1), 1-15.

Bernanke, B., Gertler, M., Gilchrist, S., 1999. The financial accelerator in a quantitative business cycle framework. Chapter 21 in Handbook of Macroeconomics 1 (C), 1341-1393.

Bertay, A. C. Demirgüç-Kunt, A., Huizinga, H., 2015. Bank ownership and credit over the business cycle: Is lending by state banks less procyclical? Journal of Banking \& Finance 50 (C), 326-339.

Bikker, J., Metzemakers, P., 2005. Bank provisioning behavior and procyclicality. Journal of International Financial Markets, Institutions and Money 15 (2), 141-157.

Blundell, R., Bond, S., 1998. Initial conditions and moment restrictions in dynamic panel data models. Journal of Econometrics 87 (1), 115-143.

Bodman, P.M., 2001. Steepness and deepness in the Australian macroeconomy. Applied Economics 33 (3), 375-382.

Braun, M., Larrain, B., 2005. Finance and the business cycle: International, inter-industry evidence. Journal of Finance 60 (3), 1097-1128.

Caballero, R., Krishnamurthy, A., 2001. International and domestic collateral constraints in a model of emerging market crises. Journal of Monetary Economics 48 (3), 513-548. 
Caballero, R., Simsek, A., 2013. Fire sales in a model of complexity. Journal of Finance 68 (6), 2549-2587.

Caldara, D., Fuentes-Albero, C., Gilchrist, S., Zakrajsek, E., 2016. The macroeconomic impact of financial and uncertainty shocks. European Economic Review 88 (C), 185-207.

Calderón, C., Schmidt-Hebbel, K., 2008. Openness and growth volatility. Working paper No. 483, Central Bank of Chile.

Calderón, C., Fuentes, J. R., 2014. Have business cycles changed over the last two decades? An empirical investigation. Journal of Development Economics 109 (C), 98-123.

Campello, M., Graham, J., Harvey, C., 2010. The real effects of financial constraints: Evidence from a financial crisis. Journal of Financial Economics 97 (3), 470-487.

Caner, M., Hansen, B., 2004. Instrumental variable estimation of a threshold model. Econometric Theory 20 (5), 813-843.

Cecchetti, S. G., Krause, S., 2001. Financial structure, macroeconomic stability and monetary policy. NBER working paper, No. 8354.

Chan, K., Dang, V., Yan, I., 2012. Chinese firms' political connection, ownership, and financing constraints. Economics Letters 115 (2), 164-167.

Chang, P., Jia, C., Wang, Z., 2010. Bank fund reallocation and economic growth: Evidence from China. Journal of Banking \& Finance 34 (11), 2753-2766.

Chen, G., Firth, M., Xu, L., 2009. Does the type of ownership control matter? Evidence from China's listed companies. Journal of Banking \& Finance 33 (1), 171-181.

Chen, S., Sun, Z., Tang, S., Wu, D., 2011. Government intervention and investment efficiency: Evidence from China. Journal of Corporate Finance 17 (2), 259-271.

Chen, Y., Liu, M., Su, J., 2013. Greasing the wheels of bank lending: Evidence from private firms in China. Journal of Banking \& Finance 37 (7), 2533-2545.

Chernozhukov, V., Fernandez-Val, I., Hahn, J., Newey, W., 2013. Average and quantile effects in nonseparable panel models. Econometrica 81 (2), 535-580. 
Chinn, M. D., Ito, H., 2006. What matters for financial development? Capital controls, institutions, and interactions. Journal of Development Economics 81 (1), 163-192.

Chodorow-Reich, G., 2014. The employment effects of credit market disruptions: Firm-level evidence from the 2008-09 financial crisis. Quarterly Journal of Economics 129 (1), 1-59.

Claessens, S., Feijen, E., Laeven, L., 2008. Political connections and preferential access to finance: The role of campaign contributions. Journal of Financial Economics 88 (3), $554-580$.

Claessens, S., Kose, M. A., Terrones, M.E., 2009. What happens during recessions, crunches and busts? Economic Policy 24 (60), 653-700.

Claessens. S., Kose, M., Terrones, M., 2012. How do business and financial cycles interact. Journal of International Economics 87 (1), 178-90.

Corsetti, G., Meier, A., Muller, G., 2012. What determines government spending multipliers? Economic Policy 27 (72), 521-565.

Cull, R., Xu, L., 2003, Who gets credit? The behavior of bureaucrats and state banks in allocating credit to Chinese state-owned enterprises. Journal of Development Economics 71 (2), 533- 559.

Dabla-Norris, E., Srivisal, N., 2013. Revisiting the link between finance and macroeconomic volatility. IMF Working Paper 13/29.

Dell' Ariccia, G., Detragiache, E., Rajan, R., 2008. The real effect of banking crisis. Journal of Financial Intermediation 17 (1), 89-112.

Denizer, C., Iyigun, M., Owen, A., 2002. Finance and macroeconomic volatility. Contributions to Macroeconomics 2 (1), Article 7.

Di Giovanni, J., Levchenko, A. A., 2009. Trade openness and volatility. Review of Economics and Statistics 91 (3), 558-585.

Diamond, D., Rajan, R., 2011. Fear of fire sales, illiquidity seeking and the credit freeze. Quarterly Journal of Economics 126 (2), 557-591.

Drakos, K., Giannakopoulos, N., 2011. On the determinants of credit rationing: Firm-level 
evidence from transition countries. Journal of International Money and Finance 30 (8), 1773-1790.

Duarte, M., Restuccia, D., Waddle, A. L., 2007. Exchange rates and business cycles across countries. Economic Quarterly 93 (1), 57-76.

Dynan, K. E., Elmendorf, D. W., Sichel, D. E., 2006. Can financial innovation help to explain the reduced volatility of economic activity. Journal of Monetary Economics 53 (1), 123-150.

Easterly, W., Islam, R., Stiglitz, J., 2001. Shaken and stirred: Explaining growth volatility. In: Annual World Bank Conference on Development Economics, 191-211.

Egert, B., Sutherland, D., 2014. The nature of financial and real business cycle: The great moderation and banking sector pro-cyclicality. Scottish Journal of Political Economy $61(1), 98-117$.

Faccio, M., Masulis, R., McConnell, J., 2006. Political connections and corporate bailouts. Journal of Finance 61 (6), 2597-2635.

Faccio, M., 2010. Differences between politically connected and nonconnected firms: A cross-country analysis. Financial Management 39 (3), 905-928.

Faia, E., 2007. Financial differences and business cycle co-movements in a currency area. Journal of Money, Credit and Banking 39 (1), 151-185.

Fama, E., French, K., 1998. Taxes, financing decisions, and firm value. Journal of Finance 53 (3), 819-843.

Fernández, A., González, F., Suárez, N., 2016. Banking stability, competition, and economic volatility. Journal of Financial Stability 22 (C), 101-120.

Ferrante, F., 2015. A model of endogenous loan quality and the collapse of the shadow banking system, Finance and Economics Discussion Series 2015-021. Washington: Board of Governors of the Federal Reserve System.

Ferreira da Silva, G., 2002. The impact of financial system development on business cycles volatility: Cross-country evidence. Journal of Macroeconomics 24 (2), 233-253. 
Firth, M., Lin, C., Liu, P., Wong, S., 2009. Inside the black box: Bank credit allocation in China's private sector. Journal of Banking \& Finance 33 (6), 1144-1155.

Jefferson, G., 2016. State-owned enterprise in China: Reform, performance, and prospects. No. 109, Working Papers from Brandeis University, Department of Economics and International Business School.

Gali, J., Perotti, R., 2003. Fiscal policy and monetary integration in Europe. Economic Policy 18 (37), 533-572.

Galindo, A., Schiantarelli, F., 2003. Credit constraints and investment in Latin America. Inter-American Development Bank, Washington, DC.

Galvao Jr., A. F., 2011. Quantile regression for dynamic panel data with fixed effects. Journal of Econometrics 164 (1), 142-157.

Garcia, R., Schaller, H., 2002. Are the effects of monetary policy asymmetric? Economic Inquiry 40 (1), 102-119.

Garmaise, M., 2008. Production in entrepreneurial firms: The effects of financial constraints on labor and capital. Review of Financial Studies 21(2), 543-577.

Greenwood, J., Jovanovic, B., 1990. Financial development, growth, and the distribution of income. Journal of Political Economy 98 (5), 1076-1107.

Gertler, M., Karadi, P., 2011. A model of unconventional monetary policy. Journal of Monetary Economics 58 (1), 17-34.

Gurley, J. G., Shaw, E. S., 1955. Financial aspects of economic development. American Economic Review 45 (4), 515-538.

Hadlock, C., Pierce, J., 2010. New evidence on measuring financial constraints: Moving beyond the KZ Index. Review of Financial Studies 23 (5), 1909-1940.

Halvorsen, J., Jacobsen, D., 2014. How important can bank lending shocks be for economic fluctuations. North American Journal of Economics and Finance 29 (C), $104-123$.

Hansen, B., 1999. Threshold effects in non-dynamic panels: Estimation, testing, and inference. Journal of Econometrics 93 (2), 345-368. 
Hansen, B., 2000. Sample splitting and threshold estimation. Econometrica 68 (3), $575-603$.

Hasan, F., Koetter, M., Wedow, M., 2009. Regional growth and finance in Europe: Is there a quality effect of bank efficiency. Journal of Banking \& Finance 33 (8), 1446-1453.

Huang, Y., 2008. Capitalism with Chinese characteristics: State and entrepreneurship during reform. New York, NY: Cambridge University Press.

Huynh, K., Petrunia, R., 2010. Age effects, leverage and firm growth. Journal of Economic Dynamics and Control 34 (5), 1003-1013.

Ibrahim, M., 2016. Business cycle and bank lending procyclicality in a dual banking system. Economic Modelling 55 (C), 127-134.

Ibrahim, M., Alagidede, P., 2017. Financial sector development, economic volatility and shocks in sub-Saharan Africa. Physica A 484 (C), 66-81.

Jappelli, T., Pistaferri, L., 2011. Financial integration and consumption smoothing. Economic Journal 121 (553), 678-706.

Jensen, M., Meckling, W., 1976. Theory of the firm: Managerial behavior, agency costs of ownership structure. Journal of Financial Economics 3 (4), 305-360.

Jin, J., Kanagaretnam, K., Lobob, G., 2011. Ability of accounting and audit quality variables to predict bank failure during the financial crisis. Journal of Banking \& Finance 35 (11), 2811-2819.

Jordà, Ò., Schularick, M., Taylor, A., 2013. When credit bites back. Journal of Money, Credit and Banking 45 (s2), 3-28.

Kalemli-Ozcan, S., 2002. Does mortality decline promote economic growth? Journal of Economic Growth 7 (4), 411-439.

Kalemli-Ozcan, S., 2003. A stochastic model of mortality, fertility, and human capital investment. Journal of Development Economics 70 (1), 103-118.

Kaplan, S., Zingales, L., 1997. Do investment-cash flow sensitivities provide useful measures of financing constraints? Quarterly Journal of Economics 115 (2), 707-12. 
Kashyap, A., Stein, J., 2004. Cyclical implications of the Basel II capital standards. Economic Perspectives 28 (1), 18-31.

Kato, K., Galvao, A. F., Montes-Rojas, G. V., 2012. Asymptotics for panel quantile regression models with individual effects. Journal of Econometrics 170 (1), 76-91.

Keynes, J. M., 1936. The General Theory of Employment, Interest, and Money. MacMillan, London.

Kiani, K. M., Bidarkota, P. V., 2004. On business cycle asymmetries in G7 countries. Oxford Bulletin of Economics and Statistics 66 (3), 333-351.

Kilian, L., Vigfusson, R. J., 2011a. Are the responses of the U.S. economy asymmetric in energy price increases and decreases? Quantitative Economics 2 (3), 419-453.

Kilian, L., Vigfusson, R. J., 2011b. Nonlinearities in the oil price-output relationship. Macroeconomic Dynamics 15 (S3), 337-363.

King, R., Levine, R., 1993. Finance and growth: Schumpeter might be right. Quarterly Journal of Economics 108 (3), 717-737.

Kiyotaki, N., Moore, J., 1997. Credit cycles. Journal of Political Economy 105 (2) 211-248.

Kletzer, K., Bardhan, P., 1987. Credit markets and patterns of international trade. Journal of Development Economics 27 (1-2), 57-70.

Koenker, R., Bassett, G. W., 1978. Regression quantiles. Econometrica 46 (1), 33-49.

Koenker, R., 2004. Quantile regression for longitudinal data. Journal of Multivariate Analysis 91 (1), 74-89.

Koetter, M., Wedow, M., 2010. Finance and growth in a bank-based economy: Is it quantity or quality that matters. Journal of International Money and Finance 29 (8), 1529-1545.

Kose, A., Prasad, E., Terrones, M., 2003. Financial integration and macroeconomic volatility. IMF Staff Papers 50, 119-141.

Kose, M. A., Yi, K. M., 2006. Can the standard international business cycle model explain 
the relation between trade and comovement? Journal of International Economics 68 (2), 267-295.

Kose, M. A., Otrok, C., Prasad, E., 2008. Global business cycles: Convergence or decoupling? Working Papers No. 14292. Cambridge: National Bureau of Economic Research.

Kremer, S., Bick, A., Nautz, D., 2013. Inflation and growth: New evidence from a dynamic panel threshold analysis. Empirical Economics 44 (2), 861-878.

Kunieda, T., 2008. Financial development and volatility of growth rates: New evidence. Ryukoku University, mimeo.

Lamarche, C., 2010. Robust penalized quantile regression estimation for panel data. Journal of Econometrics 157 (2), 396-408.

Lane, P., 2003. The cyclicality of fiscal policy: Evidence from the OECD. Journal of Public Economics 87 (12), 2661-2675.

Lang, L., Ofek, E., Stulz, R., 1996. Leverage, investment, and firm growth. Journal of Financial Economics 40 (1), 3-29.

Levine, R., 1997. Financial development and economic growth: Views and agenda. Journal of Economic Literature 35 (2), 688-726.

Levine, R., Loayza, N., Beck, T., 2000. Financial intermediation and growth: Causality and causes. Journal of Monetary Economics 46 (1), 31-77.

Lin, C., Ma, Y., Xuan, Y., 2011. Ownership structure and financial constraints: Evidence from a structural estimation. Journal of Financial Economics 102 (2), 416-431.

Liu, Q., Pan, X., Tian, G., 2018. To what extent did the economic stimulus package influence bank lending and corporate investment decisions? Evidence from China, Journal of Banking \& Finance 68, 177-193.

Lo, M. C., Piger, J., 2005. Is the response of output to monetary policy asymmetric? Evidence from a regime-switching coefficients model. Journal of Money, Credit and Banking 37 (5), 865-886.

Love, I., 2003. Financial development and financing constraints: International evidence 
from the structural investment model. Review of Financial Studies 16 (3), 765-791.

Love, I., Zicchino, L., 2006. Financial development and dynamic investment behavior: Evidence from panel VAR. Quarterly Review of Economics and Finance 46 (2), 190-210.

Lowe, P., Segoviano, M., 2002. Internal ratings, the business cycle and capital requirements: Some evidence from an emerging market economy. BIS Working Paper 117.

Ma, Y., Zhang J., 2016. Financial cycle, business cycle and monetary policy: Evidence from four major economies. International Journal of Finance \& Economics 21 (4), $502-527$.

Magud, N. E., 2008. On asymmetric business cycles and the effectiveness of counter-cyclical fiscal policies. Journal of Macroeconomics 30 (3), 885-905.

Mandelman, F., 2010. Business cycles and monetary regimes in emerging economies: A role for a monopolistic banking sector. Journal of International Economics 81 (1), $122-138$.

Mangelli, S., Popov, A., 2015. Financial development, sectoral reallocation, and volatility: International evidence. Journal of International Economics 96 (2), 323-337.

McConnell, J., Servaes, H., 1995. Equity ownership and the two faces of debt. Journal of Financial Economics 39 (1), 131-157.

Mimir, Y., 2016. Financial intermediaries, credit shocks and business cycles. Oxford Bulletin of Economics and Statistics 78 (1), 42-74.

Mitchell, W., 1927. Business cycles: The problem and its setting. National Bureau of Economic Research, New York.

Modigliani, F., Miller, M., 1958. The cost of capital, corporation finance and the theory of investment. American Economic Review 48 (3), 261-97.

Mohaddes, K., Pesaran, M. H., 2016. Country-specific oil supply shocks and the global economy: a counterfactual analysis. Energy Economics 59 (C), 382-399. 
Mohaddes, K., Pesaran, M. H., 2017. Oil prices and the global economy: Is it different this time around? Energy Economics 65, 315-325.

Myers, S., Majluf, N., 1984. Corporate financing and investment decision when firms have information that investors do not have. Journal of Financial Economics 13 (2), $187-221$.

Narayan, P. K., Narayan, S., 2008. Examining the asymmetric behavior of macroeconomic aggregates in Asian economies. Pacific Economic Review 13 (5), $567-574$.

Narayan, P .K., 2009. Are health expenditures and GDP characterized by asymmetric behavior? Evidence from 11 OECD countries. Applied Economics 41 (4), 531-536.

Nolan, C., Thoenissen, C., 2009. Financial shocks and the US business cycle. Journal of Monetary Economics 56 (4), 596-604.

Obstfeld, M., 1994. Risk-taking, global diversification, and growth. American Economic Review 84 (5), 1310-1329.

Ouyang, M., Peng, Y., 2015. The treatment-effect estimation: A case study of the 2008 economic stimulus package of China. Journal of Econometrics 188 (2), 545-557.

Pagano, M., 1993. Financial markets and growth: An overview. European Economic Review 37 (2-3), 613-622.

Pagano, M., Pica, G., 2012. Finance and employment. Economic Policy 27 (69), 5-55.

Pederzoli, C., Torricelli, C., 2005. Capital requirements and business cycle regimes: Forward-looking modeling of default probabilities. Journal of Banking \& Finance 29 (12), 3121-3140.

Poncet, S., Steingress, W., Vandenbussche, H., 2010. Financial constraints in China: Firm-level evidence. China Economic Review 21 (3), 411-422.

Powell, D., 2016a. Quantile regression with nonadditive fixed effects. RAND Labor and Population Working Paper.

Powell, D., 2016b. Quantile treatment effects in the presence of covariates. RAND Labor and Population Working Paper. 
Rajan, R., Zingales, L., 1998. Financial dependence and growth. American Economic Review 88 (3), 559-586.

Ramsey, J. B., Rothman, P., 1996. Time irreversibility and business cycle asymmetry. Journal of Money, Credit and Banking 28 (1), 1-21.

Ramey, G., Ramey, V., 1995. Cross-country evidence on the link between volatility and growth. American Economic Review 85 (5), 1138-1151.

Roodman, D., 2009. A note on the theme of too many instruments. Oxford Bulletin of Economics and Statistics 71 (1), 135-158.

Rosen, A. M., 2012. Set identification via quantile restrictions in short panels. Journal of Econometrics 166 (1), 127-137.

Santoro, E., Petrella, I., Pfajfar, D., Gaffeo, E., 2014. Loss aversion and the asymmetric transmission of monetary policy. Journal of Monetary Economics 68 (C), 19-36.

Schiffer, M., Weder, B., 2001. Firm size and the business environment: Worldwide survey results. Discussion Paper No. 43, International Finance Corporation, Washington, DC.

Schumpeter, J., 1912. The theory of economic development. Oxford University Press, Oxford.

Schumpeter, J., 1934. The theory of economic development: An inquiry into profits, capital, credits, interest, and the business cycle. Transaction Publishers, Piscataway.

Sichel, D., 1993. Business cycle asymmetry: A deeper look. Economic Inquiry 31 (2), 224-236.

Tang, S., Groenewold, N., Leung, C., 2008. The link between institutions, technical change and macroeconomic volatility. Journal of Macroeconomics 30 (4), 1520-1549.

Wang, J., 2014. Corporate investments in Asian markets: Financial conditions, financial development, and financial constraints. World Development 57, 63-78.

Wang, P., Wen, Y., Xu, Z., 2016. Financial development and long-run volatility trends. Federal Reserve Bank of St. Louis, Research Division, working paper series.

Wen, Y., Wu, J., 2014. Withstanding great recession like China. Working Paper 
2014-007A. Federal Reserve Bank of St. Louis.

Whited, T., Wu, G., 2006. Financial constraints risk. Review of Financial Studies 19 (2), 531-59.

World Economic Outlook, 2013. http://www.imf.org/external/pubs/ft/weo/2013/02/

World Economic Outlook, 2014. http://www.imf.org/external/pubs/ft/weo/2014/02/

Wurgler, J., 2000. Financial markets and the allocation of capital. Journal of Financial Economics 58 (1-2), 187-214.

Zhang, J., Wang, L., Wang, S., 2012. Financial development and economic growth: Recent evidence from China. Journal of Comparative Economics 40 (3), 393-412. 
VITA

\section{WENJUN XUE}

2010

2013

2015

2018

2015-2018
B.S., Finance

Shanghai University

M.S., Econometrics

Shanghai University

M.A., Economics

Central Michigan University

Ph.D. candidate, Economics

Florida International University

Graduate Teaching Assistant

Florida International University 